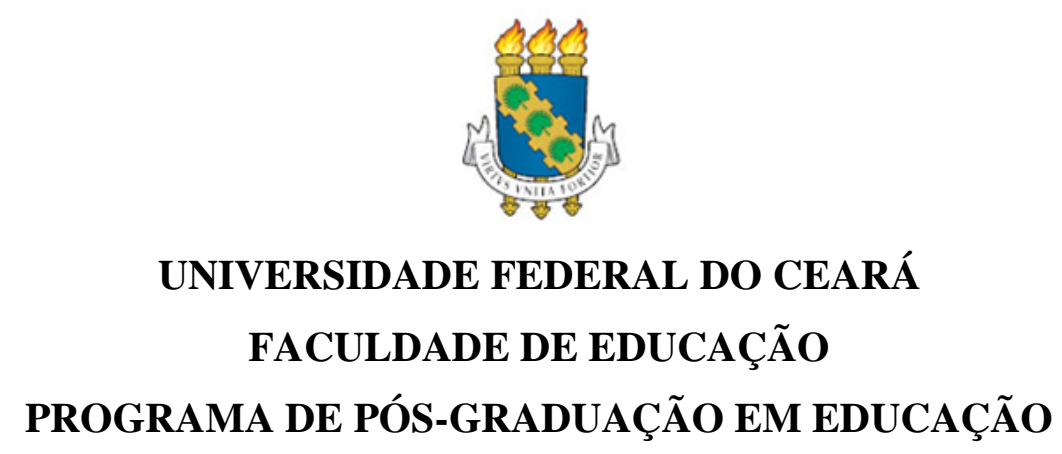

MARÍLIA MAIA MOREIRA

ANÁLISE DA VISÃO DO PROFESSOR-TUTOR SOBRE A ADEQUABILIDADE DO MATERIAL DIDÁTICO DE MATEMÁTICA À LUZ DA SEQUÊNCIA FEDATHI: O CASO DA LICENCIATURA EM MATEMÁTICA DO IFCE

FORTALEZA 
Dissertação apresentada ao Programa de PósGraduação em Educação da Universidade Federal do Ceará, como requisito à obtenção do título de Mestre em Educação. Área de concentração: Tecnologias Digitais na Educação.

Orientadora: Prof. $^{\text {a }}$ Dr. ${ }^{\text {a }}$ Cassandra Ribeiro Joye.

Co-orientador: Prof. Dr. Hermínio Borges Neto. 
Dados Internacionais de Catalogação na Publicação

Universidade Federal do Ceará

Biblioteca de Ciências Humanas

M838a Moreira, Marília Maia.

Análise da visão do professor-tutor sobre a adequabilidade do material didático de matemática à luz da Sequência Fedathi : o caso da licenciatura em matemática do IFCE / Marília Maia Moreira. - 2014. $146 \mathrm{f}$. : il. color., enc. ; $30 \mathrm{~cm}$.

Dissertação (mestrado) - Universidade Federal do Ceará, Faculdade de Educação, Programa de PósGraduação em Educação Brasileira, Fortaleza, 2014.

Área de Concentração: Tecnologia educacional; ensino de ciências e matemática; ensinoaprendizagem.

Orientação: Profa. Dra. Cassandra Ribeiro Joye.

Coorientação: Prof. Dr. Hermínio Borges Neto.

1.Fedathi,Sequência. 2.Preceptores - Atitudes - Fortaleza(CE). 3.Material didático digital Fortaleza $(\mathrm{CE})$. 4.Ensino à distância - Fortaleza $(\mathrm{CE})$. 5.Ensino semipresencial - Fortaleza(CE). 6.Cálculo diferencial - Estudo e ensino(Superior). 7.Instituto Federal de Educação,Ciência e Tecnologia do Ceará (Fortaleza,CE). I. Título. 


\title{
ANÁLISE DA VISÃO DO PROFESSOR-TUTOR SOBRE A ADEQUABILIDADE DO MATERIAL DIDÁTICO DE MATEMÁTICA À LUZ DA SEQUÊNCIA FEDATHI: $O$ CASO DA LICENCIATURA EM MATEMÁTICA DO IFCE
}

\begin{abstract}
Dissertação apresentada ao Programa de PósGraduação em Educação da Universidade Federal do Ceará, como requisito parcial à obtenção do título de Mestre em Educação. Área de concentração: Tecnologias Digitais na Educação.
\end{abstract}

Aprovada em:

BANCA EXAMINADORA

Prof. $^{\text {a }}$ Dr. ${ }^{\text {a }}$ Cassandra Ribeiro Joye (Orientadora)

Universidade Federal do Ceará (UFC)

Prof. Dr. Hermínio Borges Neto (Co-orientador) Universidade Federal do Ceará (UFC)

Prof. ${ }^{a}$ Dr. ${ }^{a}$ Suzana Maria Capelo Borges

Universidade Estadual do Ceará (UECE) 


\section{DEDICATÓRIA}

A Deus.

Aos meus pais, José Ferreira e Célia Maia. 


\section{AGRADECIMENTOS}

Primeiro, e sempre será o primeiro, agradeço a Deus, Figura Sublime e Magnânima que nunca deixou de me guiar e sempre estará ao meu lado. Guia-me tanto em minhas alegrias, como em minhas tristezas. Deveras, Ele me guia.

À minha família, aos meus pais, tios e tias, irmão e irmãs, em especial às minhas irmãs Josi Maia e Lilian Maia que, em momentos de alegrias e angústias, me apoiaram.

À minha orientadora, a Prof ${ }^{\mathrm{a}}$. Dr ${ }^{\mathrm{a}}$. Cassandra Ribeiro Joye, que, muito pacientemente, soube compreender o desenvolvimento de minha maturidade intelectual e sempre me guiou para o desenvolvimento dessa pesquisa.

Ao Prof. Dr. Hermínio Borges Neto que, na figura de co-orientador, contribuiu com sua experiência acadêmica em minha pesquisa e no meu amadurecimento pessoal e intelectual.

Às minhas amigas Lourdes Sousa, Ana Cláudia Pinheiro, Iraci Moraes e Jane Guedes por terem me ajudado a amadurecer as minhas ideias e me fazer crescer como pessoa também.

À coordenação da pós-graduação em Educação Brasileira, em especial aos funcionários Sérgio, Geisa, Ariadina, Adalgisa, Pedro Rogério; e o coordenador João Figueiredo.

À equipe da Comissão de Bolsas do qual fiz parte, vigência 2012-2014, na qual conquistei amigos e fui conquistada por eles também. Agradeço a Flávio Muniz, Filipe Jesuíno e Francione Charapa.

Aos meus colegas da Diretoria de Educação a Distância do Instituto Federal do Ceará. A equipe de Produção de Material Didático de onde o meu objeto de estudo emergiu, em especial à Samantha Onofre por ter me ajudado a fazer as transcrições das entrevistas.

Aos professores-tutores que participaram da pesquisa, os quais foram de grande importância para delinear os traços teóricos dela.

Ao professor Raimundo Nonato Araújo, por me incentivar e me ajudar na busca pelo objetivo dessa pesquisa. 
Aos meus colegas de pesquisa do Laboratório de Pesquisa MultiMeios da Universidade Federal do Ceará.

A todos os meus amigos que conheci no início, meio e fim de meu mestrado e que, de certa forma, tiveram cada um a sua importância em minha vida. Agradeço a Ana Flower, Jaíza Helena, Neidimar Lopes, Mirley Nádila, Ângela Sousa, entre outros que conheci nessa trajetória.

A todos os professores desse curso de Pós-graduação em Educação Brasileira que, na tentativa de preparar a mim e aos meus colegas, fizeram a sua parte contribuindo com o seu conhecimento acadêmico.

À participação da Prof $^{a}$. Dr ${ }^{a}$. Suzana Maria Capelo Borges na composição da banca de avaliação desse trabalho de pesquisa.

À Fundação Cearense de Apoio ao Desenvolvimento Científico e Tecnológico (FUNCAP) por ter financiado essa pesquisa com a manutenção da bolsa de estudo. 


\section{RESUMO}

Esta pesquisa teve como foco a análise da visão do professor-tutor sobre a adequação do material didático de Matemática à modalidade semipresencial de ensino superior. Como parte do arcabouço teórico necessário para se realizar essa análise, fez-se uma retrospectiva histórica do ensino de Matemática (com ênfase no ensino de Cálculo) em duas das principais instituições de ensino superior do país: a Universidade Federal do Rio de Janeiro e a Universidade de São Paulo, desde o Império até os dias atuais. Também foi desenvolvida nesta pesquisa uma análise comparativa de livros-textos que foram usados como base para o ensino de Cálculo nessas instituições de ensino superior. Discutiu-se ainda o conceito de material didático para ensino superior a distância, assim como se descreveu o material didático de Matemática para essa modalidade de ensino. A abordagem metodológica tratou-se de uma pesquisa-ação, na qual se partiu de um estudo particular de um objeto para se chegar a conclusões gerais. Na coleta dos dados, foram ouvidos os professores-tutores, oriundos do Instituto Federal de Educação, Ciência e Tecnologia do Ceará (IFCE), mediante entrevistas, utilizando-se de um questionário constituído de questões abertas. A metodologia de base para a construção desse questionário se pautou na teoria Sequência FEDATHI. A pesquisa ainda tratou de verificar se há evidências da presença de uma transposição didática, especificamente a presença da teoria Sequência FEDATHI, no Material Didático de Cálculo I produzido pelo IFCE para o curso semipresencial de Licenciatura em Matemática. Dessa verificação, constatou-se que a proposta de se utilizar a Sequência FEDATHI como uma das metodologias de base para a construção de um material didático de Matemática para ensino a distância é um ideal que ainda não foi alcançado. Outra constatação é que o atual material didático de Cálculo I ainda não está didaticamente adequado ao seu público-alvo e deve passar por uma reformulação didática.

Palavras-chave: Sequência FEDATHI. Análise da Visão do Professor-Tutor. Adequabilidade. Material Didático. Licenciatura em Matemática Semipresencial. 


\begin{abstract}
This research focused on the analysis of the teacher-tutor's view of the adequacy of the teaching material of Mathematics to the blended form of higher education. As part of the theoretical framework necessary to perform this analysis, there was a historical retrospective mathematics teaching (with emphasis on the calculation of education) in two of the main higher education institutions of the country: the Federal University of Rio de Janeiro and the University of São Paulo, from the Empire to the present day. It was also developed in this research a comparative analysis of textbooks that were used as the basis for the calculation of teaching in these institutions of higher education. It also discussed the concept of teaching materials for distance higher education, as well as described the courseware Mathematics for this type of education. The methodological approach was treated to an action research, in which it came from a particular study of an object to reach general conclusions. For data collection, were heard teachers, tutors, coming from the Federal Institute of Education, Science and Technology of Ceará (IFCE), through interviews, using a questionnaire consisting of open questions. The basic methodology for the construction of the questionnaire was based on FEDATHI Sequence theory. The survey also tried to check for evidence of the presence of a didactic transposition, specifically the presence of FEDATHI Sequence theory in Courseware Calculus I produced by IFCE for blended Degree in Mathematics. This verification, it was found that the proposal to use the FEDATHI sequence as one of the basic methodologies for the construction of a mathematics teaching materials for distance learning is an ideal that has not yet been reached. Another finding is that the current courseware Calculus I is still not didactically appropriate to your target audience and must pass a didactic makeover.
\end{abstract}

Keywords: Sequence Fedathi. Analysis of Teacher-Tutor Vision. Suitability. Educational Material. Degree in Mathematics semipresential. 


\section{LISTA DE ILUSTRAÇÕES}

Figura 1 - À esquerda a capa do livro de Lacroix; e à direita a capa do livro de Sonnet.......... 34 Figura 2 - À esquerda a capa do livro de Louis Leithold, no centro a capa do livro de Halmilton Guidorizzi e à direita a capa do livro de James Stewart. .......................................38 Figura 3 - Tela do recurso digital 'box icone' em um MD digital produzido pela UAB do IFCE. 53

Figura 4 - Tela do recurso digital 'slidershow' em um MD digital produzido pela UAB do IFCE.

Figura 5 - Tela do recurso digital 'lightbox' em um MD digital produzido pela UAB do IFCE.

Figura 6 - Tela do recurso digital 'pop-up janela' em um MD digital produzido pela UAB do IFCE. 55

Figura 7 - Comparação da Taxonomia de Bloom antes e depois de ser revisada. 59

Figura 8 - Competências a se desenvolver no aluno na Taxonomia de Bloom Digital 60

Figura 9 - Triângulo pedagógico do ensino e aprendizagem 61

Figura 10 - As variantes que estão ligadas a transposição didática no processo de ensino 63

Figura 11- Formação acadêmica de cada professor-tutor entrevistado. 75

Figura 12 - As quatro etapas da Sequência FEDATHI 79

Figura 13 - As etapas da Sequência Fedathi e sua relação com cada pergunta do questionário da entrevista. 80

Figura 14 - Relação entre a Aula 7 e as outras primeiras aulas do MD de Cálculo I. .84 


\section{LISTA DE QUADROS}

Quadro 1 - Comparação entre livros-textos adotados ou traduzidos e as abordagens dos conceitos de cálculo nas duas principais instituições de ensino superior do Brasil entre 1808 a 1932 35

Quadro 2 - Comparação entre livros-textos adotados ou traduzidos atualmente por diversas instituições de ensino superior entre 1970 aos dias de hoje 39

Quadro 3 - Características das relações entre professor-aluno-saber 61

Quadro 4 - Conteúdos explorados na disciplina de Cálculo I da Licenciatura em Matemática semipresencial do IFCE. 70 


\section{LISTA DE ABREVIATURAS E SIGLAS}

ABED Associação Brasileira de Educação a Distância

AVA Ambiente Virtual de Aprendizagem

CAPES Coordenação de Aperfeiçoamento de Pessoal de Nível Superior

Cálculo I Cálculo Diferencial e Integral I

DEaD Diretoria de Educação a Distância

DI Designer Instrucional

DIC Design Instrucional Contextualizado

EaD Educação a Distância

EPCT Educação Profissional, Científica e Tecnológica

e-Tec Educação Profissional e Tecnológica na modalidade a distância

FNFi Faculdade Nacional de Filosofia

IFCE Instituto Federal de Educação, Ciência e Tecnológica do Ceará

MD Material Didático

MEC Ministério da Educação

PUD Programa de Unidade Pedagógica

SETEC Secretaria de Educação Profissional e Tecnológica

UAB Universidade Aberta do Brasil

$\mathrm{UBr} \quad$ Universidade do Brasil

USP Universidade de São Paulo

UFC Universidade Federal do Ceará

URJ Universidade do Rio de Janeiro

UFRJ Universidade Federal do Rio de Janeiro 


\section{SUMÁRIO}

1 INTRODUÇÃ

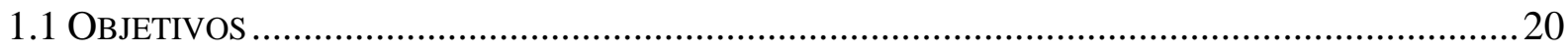

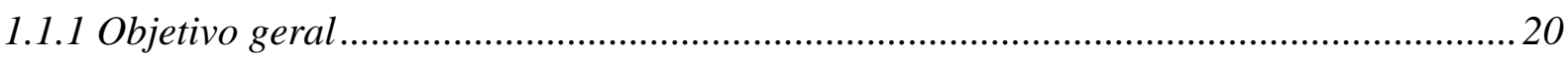

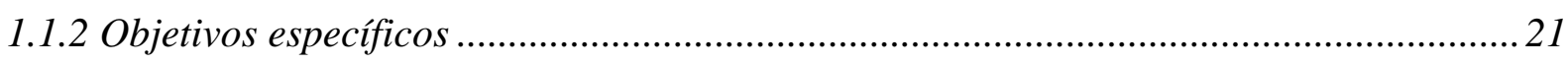

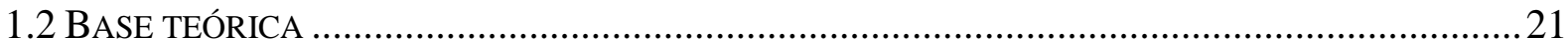

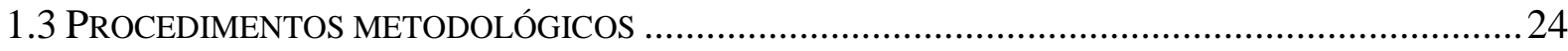

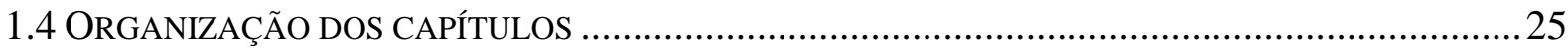

\section{EXTRATOS HISTÓRICOS E A TRADIÇÃO DO USO DE LIVROS-TEXTOS NO} ENSINO DE CÁLCULO NO BRASIL ...................................................................................227

2.1 Breve retrospectiva do Ensino de CÁlculo no Ensino Superior Brasileiro do

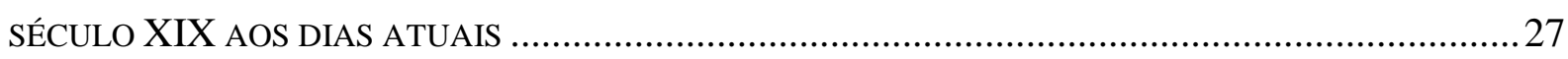

2.1.1 Ensino de Cálculo na Universidade Federal do Rio de Janeiro..................................... 28

2.1.2 Ensino de Cálculo na Universidade de São Paulo........................................................... 32

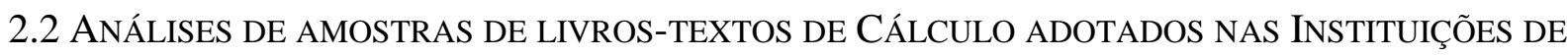

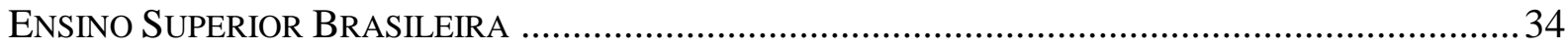

\section{MATERIAL DIDÁTICO DE MATEMÁTICA NA EDUCAÇÃO A DISTÂNCIA ..... 43}

3.1 O DESIGN InStRUCIONAL NA PRODUÇÃO DE MATERIAL DidÁtico PARA EAD .................... 43

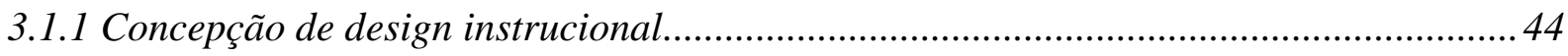

3.1.2 O design instrucional contextualizado e os principais atores na produção de material

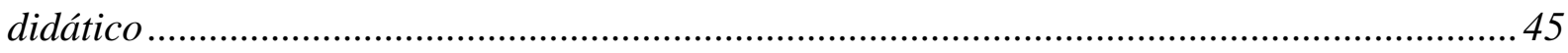

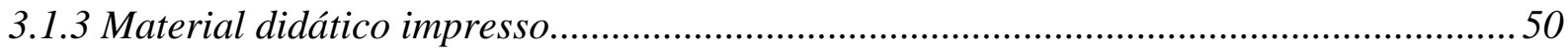

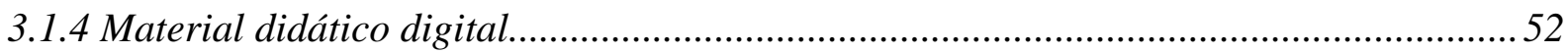

3.1.5 Características da estrutura pedagógica de um material didático para EaD ................ 56

3.2 O MATERIAL DidÁtICO DE MATEMÁTICA PARA EAD ........................................................ 61

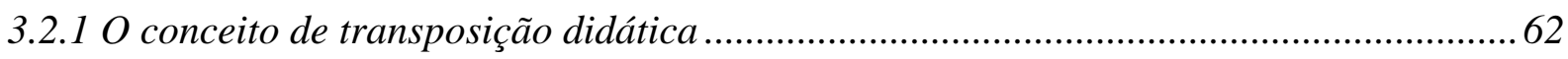

3.2.2 O papel da transposição didática na Sequência FEDATHI ......................................... 65

4 PERCURSO METODOLÓGICO DA PESQUISA........................................................67

4.1 ConTEXTO SITUACIONAL DA PESQUISA E OS EIXOS NORTEADORES ...................................67 
4.2 O ObJeto De Estudo: A Visão do Professor-TUtor sobre A AdEQUABILIDAde do

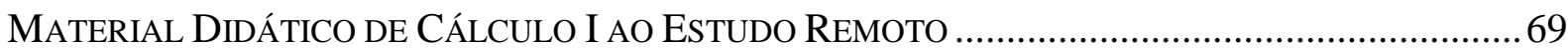

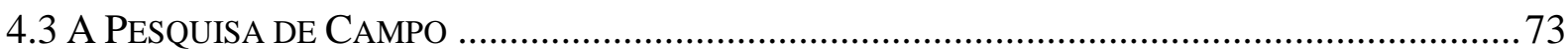

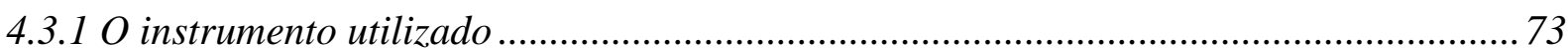

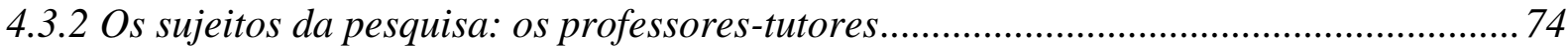

5 A VOZ DO PROFESSOR-TUTOR SOBRE O USO DO MATERIAL DIDÁTICO DE CÁLCULO I: O CASO DO IFCE ................................................................................................. 77

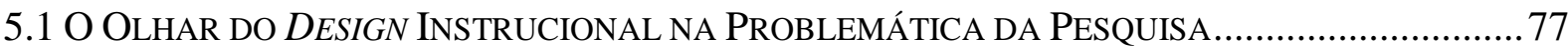

5.2 A PResença da Sequência FEDATHI no Material Didático de Cálculo I PRODUZIDO PELO IFCE: ANÁLISE DAS NARRATIVAS DOS ENTREVISTADOS ............................. 78

5.3 Outras Questões Relevantes Sobre o Material DidÁtico de CÁlCulo I ................8 88

6 CONSIDERAÇÕES FINAIS E ENCAMINHAMENTOS FUTUROS ...........................90

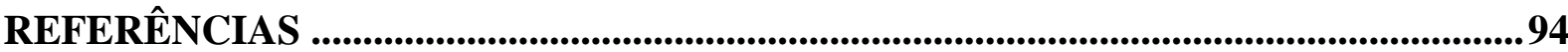

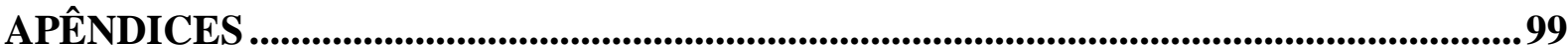

A P Ê N D I C E I - ROTEIRO PARA A ENTREVISTA SOBRE O MATERIAL DIDÁTICO DE CÁLCULO I 100

A P Ê N D I C E I I - TRANSCRIÇÃO DA ENTREVISTA COM O PROFESSOR-TUTOR 1 .................. 101

A P Ê N D I C E I I I - TRANSCRIÇÃO DA ENTREVISTA COM O PROFESSOR-TUTOR 2 ................114

A P Ê N D I C E I V - TRANSCRIÇÃO DA ENTREVISTA COM O PROFESSOR-TUTOR 3 ................ 132

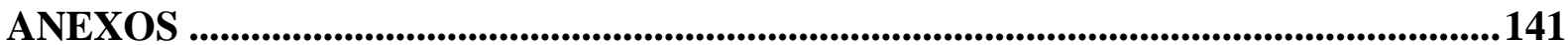

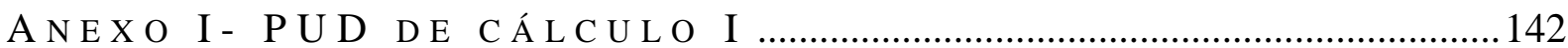

ANEXo II - SumÁRIO Do MATERIAL DidÁtiCo DE CÁlCulo I 


\section{INTRODUÇÃO}

Os dados coletados no Censo EAD.BR de 2012, divulgados pela Associação Brasileira de Educação a Distância $(\mathrm{ABED})^{1}$, apontam crescimento substancial de cursos que são ofertados a distância nos últimos anos. Verificou-se que, no ano de 2010, o número de cursos que foram autorizados no país era aproximadamente de 1.582; mas, em 2011, esse número aumentou para 3.971 cursos autorizados. Já em 2012, o quantitativo desses dados saltou para $8.249^{2}$ cursos autorizados em instituições de ensino em todo o país.

A ABED (2013) ainda reforça que, nesse mesmo intervalo de tempo, houve um crescimento expressivo da efetivação de matrículas em cursos superiores a distância no Brasil. Em 2010, esse número era de 2.261.921 matrículas em cursos nessa modalidade, enquanto que, em 2012, o número de matrículas aumentou para 5.772.466 em instituições de ensino superior.

Nesse cenário, o Instituto Federal de Educação, Ciência e Tecnologia do Ceará (IFCE) é umas dessas instituições que ofertam cursos na modalidade a distância desde 2006, com formação inicial e continuada de trabalhadores nos seguintes níveis de ensino: técnico, superior e pós-graduação. Em parceria com o Ministério da Educação (MEC), Coordenação de Aperfeiçoamento de Pessoal de Nível Superior (Capes) e Secretaria de Educação Profissional e Tecnológica (SETEC), o IFCE mantém esses níveis de ensino, através do sistema Educação Profissional e Tecnológica na modalidade a distância (e-Tec), Universidade Aberta do Brasil $(\mathrm{UAB})^{3}$, Especializações e os cursos ofertados pelo Profuncionário (SETEC/MEC).

\footnotetext{
${ }^{1}$ Para acessar o censo na íntegra, consultar site: http://www.abed.org.br/censoead/censoEAD.BR_2012_pt.pdf

${ }^{2}$ Cabe aqui ressaltar um fator a se considerar nessa pesquisa da EAD.BR de 2012: foram considerados como um conjunto os cursos completos que ensinam na modalidade a distância, assim como também as disciplinas que foram lecionadas nessa modalidade que estavam ligadas aos cursos presenciais autorizados.

${ }^{3}$ O sistema Universidade Aberta do Brasil (UAB) foi aprovado pelo Ministério da Educação, através do decreto $\mathrm{n}^{\mathrm{o}} 5.800$ de 8 de junho de 2006, com o intuito de "expandir e interiorizar a oferta de cursos e programas de educação superior no país.”. No entanto, o foco principal dessa modalidade de ensino está na formação (inicial e continuada) do professor de Ensino Básico. Para mais informações, acessar a página http://www.planalto.gov.br/ccivil_03/_ato2004-2006/2006/decreto/d5800.htm
} 
Esses programas são coordenados pela Diretoria de Educação a Distância (DEaD) do IFCE que oferta os seguintes cursos semipresenciais para o e-Tec: Edificações; Informática; Eletrotécnica; Segurança do Trabalho; Meio Ambiente; Redes de Computadores; Comércio e Agronegócio.

$\mathrm{Na}$ UAB/DEaD do IFCE, ofertam-se os cursos de Tecnologia em Hotelaria, Licenciatura em Matemática e Licenciatura em Educação Profissional, Científica e Tecnológica. Em nível de especialização, pela UAB/Secad ${ }^{4}$ e SETEC/MEC, têm-se os cursos de Educação para a Diversidade, Educação para Jovens e Adultos, Educação Ambiental, Produção de Material Didático, Turismo e Hotelaria, e Educação Profissional. Além desses, existem também os cursos que são ofertados pelo Profuncionário (SETEC/MEC/IFCE): Secretaria Escolar, Alimentação Escolar, Infraestrutura Escolar e Multimeios Didáticos pelo programa e-Tec.

Os meios e materiais de interação de que o aluno dispõe, quando ingressa em qualquer um desses cursos, são o Ambiente Virtual de Aprendizagem ${ }^{5}$ Moodle $^{6}$ - no qual a mediação é feita por tutoria presencial e a distância-; e os materiais didáticos tanto impressos como online, os quais servem para dar apoio ao ensino e aprendizagem.

Em Educação a Distância $(\mathrm{EaD})$, as informações são veiculadas e mediadas através das mídias digitais que têm como papel fornecer e propagar o conhecimento de áreas do saber de forma mais eficaz e rápida. As tecnologias que marcaram as gerações de EaD ainda convivem com tecnologias que vão desde os materiais didáticos impressos até o material online interativo ${ }^{7}$. Elas se utilizam desses recursos educacionais para prover o conteúdo didático aos estudantes que optam por estudar em um curso a distância ou semipresencial (e mesmo presencial).

\footnotetext{
${ }^{4}$ SECAD - Secretaria de Educação Continuada, Alfabetização e Diversidade.

${ }^{5} \mathrm{O}$ Ambiente Virtual de Aprendizagem (AVA) é um tipo de software que foi desenvolvido "para gerenciamento de aprendizagem via web". Ele é enriquecido por diversos instrumentos de suporte virtual de aprendizagem, tais como e-mail; fórum de discussões; chat; conteúdo programático, entre outros (MACHADO JUNIOR, 2008, p. 37-39).

${ }^{6}$ Segundo Machado Junior (2008, p. 34-35), o termo Moodle significa Modular Object Oriented Developmental Learning Environment, ou seja, um ambiente de aprendizagem orientado a objetos de desenvolvimento. O criador foi Martin Dougiamas, pesquisador na área de Ciência da Computação e Educação. O AVA Moodle é usado por diversas instituições do mundo e é gratuito de código-fonte aberto. O Moodle serve para disponibilizar recursos de ensino e aprendizagem disponíveis ao professor e aluno, respectivamente, tais como as atividades síncronas (chats, atividades presenciais, etc.) e assíncronas (fórum, atividades postadas, mídias digitais).

${ }^{7} \mathrm{O}$ material didático online é um tipo de recurso que se encontra sob a forma de hipermídia e/ou hipertexto, os quais dinamizam o conteúdo apresentado, tornando o ensino mais motivador.
} 
O material didático utilizado nos cursos da UAB/DEaD do IFCE é disponibilizado para o aluno em dois formatos: impresso e online, a fim de garantir-lhes a apropriação do conteúdo durante todo o curso. Esses materiais didáticos servem de apoio aos conteúdos teóricos específicos de cada curso, todos pautados a partir do Projeto Político Pedagógico (PPP) desses cursos.

Diante disso, optou-se, nessa pesquisa, por investigar como os tutores lidam com o material didático produzido para o curso de Licenciatura em Matemática semipresencial da UAB/DEaD do IFCE, em específico com o material didático da disciplina de Cálculo Diferencial e Integral I, comumente denominado de Cálculo I.

A escolha dessa disciplina se deu através da experiência que os profissionais de design instrucional, que lidam com a produção de material didático na EaD do IFCE, tiveram na produção desse recurso educacional ${ }^{8}$. Esse material didático apresentou particularidades, que são próprias da área de Matemática, e que levou a questionamentos sobre a sua produção e seu uso via mediação da tutoria.

Diante dessa justificativa, o objetivo principal que permeia essa pesquisa está diretamente ligado em verificar a visão do professor-tutor sobre a adequação didática do material didático da disciplina de Cálculo I do curso de Licenciatura em Matemática semipresencial do IFCE de forma a atender as necessidades de autoaprendizagem remota.

A base para essa verificação deve se apoiar em uma teoria que lide com essa adequação didática. Para essa pesquisa, a teoria adotada foi a Sequência FEDATHI. Trata-se de uma metodologia de ensino de Matemática desenvolvida por Borges Neto ${ }^{9}$, pesquisador da área de Educação Matemática, com estudos voltados para a "postura do professor" perante o ensino de conteúdos matemáticos para seus alunos (SOUZA, 2013). Essa teoria foi tomada

\footnotetext{
${ }^{8} \mathrm{Eu}$, no papel de pesquisadora e profissional da área de design instrucional, senti-me instigada em saber se o Material Didático de Cálculo I atende às necessidades básicas de ensino para que um professor-tutor pudesse ensinar o conteúdo de forma eficaz através do uso desse recurso didático, tanto impresso como web, para um curso semipresencial de Licenciatura em Matemática. Historicamente, esse conteúdo é visto por alguns professores como um tipo de 'funil' ao qual se faz uma seleção daqueles alunos que devem permanecer no curso em que há oferta dessa disciplina, tais como os diversos tipos de engenharias, os cursos das exatas e ciências da natureza, por exemplo, bacharelado e/ou licenciatura em Matemática, em Física, em Química, entre outros, uma vez que essa disciplina é pré-requisito para outras que têm o nível de abstração algébrico/geométrico/aritmético igual ou superior a esse conteúdo.

${ }^{9}$ Borges Neto é um pesquisador da área de Matemática Pura e Educação Matemática. Possui graduação, mestrado e doutorado em Matemática Pura, e pós-doutorado em Educação Matemática. É coordenador (Líder) do Laboratório de Pesquisa MultiMeios da UFC, no qual coordena vários projetos nas áreas de Educação Matemática, Inclusão Digital e EaD.
} 
como base para a criação de um questionário que foi aplicado com os professores-tutores do IFCE.

Como questões decorrentes que norteiam essa problemática, têm-se as seguintes: como o ensino de Cálculo evoluiu historicamente no nível superior no Brasil? Quais são as características que um material didático de Matemática deve ter para se adequar à modalidade semipresencial? Em se tratando do material didático de Cálculo I do curso semipresencial de Licenciatura em Matemática, como a transposição didática foi realizada na produção do conteúdo? Como o professor-tutor percebe essa transposição do material didático de Cálculo I? O que precisa melhorar / modificar na forma como o tutor se apropria do material didático para viabilizar o processo de ensino e aprendizagem?

A análise sobre a elaboração do material didático produzido na $\mathrm{UAB} / \mathrm{DEaD}$ do IFCE para as disciplinas de Cálculo é de fundamental importância para compreender o processo de ensino e aprendizagem, pois esse material didático é um instrumento de apoio a esse processo, tanto para o professor-tutor quanto para o aluno. No Guia de Livros Didáticos produzido pelo MEC, há uma citação que vale o destaque:

\footnotetext{
O livro didático [material didático] traz para o processo de ensino e aprendizagem um personagem, o seu autor, que passa a dialogar com o professor e com o aluno. Nesse diálogo, o livro é portador de escolhas sobre: o saber a ser estudado; os métodos adotados para que o aluno consiga aprendê-lo mais eficazmente; e a organização dos conteúdos ao longo dos anos de escolaridade (BRASIL, 2011, p.1213).
}

Com base nisso, pode-se perceber, nesse trecho do Guia, que o livro didático deve facilitar o processo de ensino e aprendizagem através do diálogo e da abordagem didática estabelecidos com o professor-conteudista (autor do livro) e os seus leitores: os alunos e os professores. Para esta pesquisa, o diálogo e a abordagem didática são quesitos importantes para se considerar que um material didático tem qualidade e promova bons resultados como recurso de ensino por parte do professor-tutor.

Em se tratando de conteúdos didáticos da área de Cálculo, o diálogo e a didática são ainda mais importantes. Segundo Borges Neto, Brandão e Rocha (2011), à medida que se aumenta o nível de escolaridade, os conteúdos e a linguagem Matemática passam a ser mais complexos. Por exemplo, um livro didático de nível superior, como Cálculo I, tem uma carga de conceitos, definições e teoremas que se tornam cada vez mais complexas pelo elevado grau de abstração que esse tipo de disciplina tem quando se avança em seus conceitos. Portanto, e 
ainda do ponto de vista desses autores, o sujeito que produz um livro didático deve ter a capacidade de "estabelecer diálogos com o leitor, entre o saber científico e o escolar" (BORGES NETO; BRANDÃO; ROCHA, 2011, p. 83), para tornar a apreensão desse saber dotada de significado, resultando em uma aprendizagem significativa por parte do aluno.

Da mesma forma, o material didático de ensino superior semipresencial tem que ser um facilitador do processo educacional como um todo, para que tanto professores quanto os alunos consigam apreender os conceitos explorados no saber científico ensinado.

A principal tarefa do professor, de forma geral, é transformar o saber científico em saber ensinado. Sobre isso, Joye (2013, p. 38) levanta algumas questões: “(...) como 'didatizar' os conteúdos? Como transformar o saber científico em saber escolar, reconstruído especificamente para facilitar a assimilação destes pelos alunos?”. Ao responder essas questões, compreende-se o conceito de transposição didática que é, sinteticamente, um processo de transmissão do saber científico para o saber ensinado, com o intuito de facilitar o aprendizado de certo conteúdo.

Logo, emerge-se o questionamento: como o professor-tutor percebe que o saber científico foi transformado em um saber ensinado com o uso do material didático? Desse questionamento, desprende-se: uma coisa é o professor saber para si - do conhecimento que adquiriu durante sua vida acadêmica na universidade -; outra coisa é o professor saber transferir esse conhecimento adquirido para outra pessoa. Esta pesquisa trata desse processo, considerando o material didático como um elemento para apoiar a mediação do professortutor na aprendizagem remota de seus alunos.

\subsection{Objetivos}

\subsubsection{Objetivo geral}

- Analisar a visão do professor-tutor sobre a adequação do material didático de Matemática na modalidade semipresencial de ensino superior. 


\subsubsection{Objetivos específicos}

- Descrever a evolução histórica do ensino de Cálculo no ensino superior brasileiro.

- Fazer uma análise comparativa de livros-textos utilizados em instituições de ensino superior.

- Discutir o conceito de material didático em $\mathrm{EaD}$.

- Descrever as características e particularidades do material didático de Matemática com o foco no conceito de transposição didática.

- Verificar se a Sequência FEDATHI está evidenciada como metodologia de ensino no material didático de Cálculo I produzido pelo IFCE para o curso semipresencial de Licenciatura em Matemática.

\subsection{Base teórica}

Esta pesquisa tem como objeto de estudo o material didático de Cálculo I na visão do professor-tutor e por isso mesmo não se fará uma investigação em vertentes que já foram abordadas em outras pesquisas advindos da UAB/DEaD do IFCE, tais como a pesquisa de Guedes (2011), que investigou a produção de material didático para a Licenciatura em Matemática semipresencial do IFCE, enfatizando características ergonômicas e ergopedagógicas na produção de um material didático de Matemática para esse curso; ou de Borges (2008), que desenvolveu a metodologia do DidaTIC, ferramenta de elaboração de conteúdos e atividades adequados à modalidade a distância, na qual as bases teóricas e metodológicas se apoiavam no design instrucional contextualizado e na Engenharia Didática.

Diferente daqueles, este trabalho foca em saber se o aspecto de natureza didática de um material didático de Matemática atende às necessidades de ensino de um professortutor da disciplina de Cálculo I e de aprendizagem do estudante remoto na visão desse professor-tutor que aplica a disciplina.

Para alcançar esse objetivo, realiza-se uma descrição histórica do ensino de Cálculo no Brasil, a fim de se saber como as instituições de ensino superior percebiam essa 
disciplina em seus cursos, e como os livros didáticos (materiais didáticos) abordavam esse assunto.

Algumas pesquisas já apontaram um norte na abordagem dessa temática. Segundo Oliveira (2006), Ziccardi (2009) e Lima (2012), a introdução do Cálculo no Brasil se deu em razão de uma proteção militar motivada pela vinda e instalação da Família Real Portuguesa em 1808 no país. Isso aconteceu com o intuito de que, em dois anos, depois fosse criada a Academia Real Militar do Rio de Janeiro e, no final século XIX, pudesse ter sido fundada a Politécnica de São Paulo. Esses dois fatos foram marcos importantes na história do Brasil, fatos esses que influenciaram o ensino de Cálculo.

Cabe aqui ressaltar que, na busca de elencar os principais fatos da história do ensino de Cálculo no Brasil, elucidaram-se três vertentes: o livro didático utilizado; a didática utilizada pelo professor universitário; e a transposição didática do conteúdo via livro e professor.

Em vários momentos, para elucidação das questões de pesquisa, observou-se que o livro de Cálculo foi um fator determinante na postura de professores perante o ensino de Cálculo nas principais instituições de ensino superior do país.

Aqui, nota-se a predominância da cultura europeia na adoção ou apoio de livros que abordavam os conceitos de Cálculos, tais como $\mathrm{O}$ Traité Elémentaire de Calcul Différentiel et de Calcul Intégral - livro adotado pela Academia Real Militar do Rio de Janeiro -, e o Premiers Éléments du Calcul Infinitesimal - livro adotado pela Escola Politécnica de São Paulo.

A concepção de um livro de Cálculo que tivesse preocupações didáticas de ensino e aprendizagem só foi estudada a partir do final dos anos 90 do século passado. Na época, pesquisas voltadas para essa temática abordaram a importância de haver uma concepção de um livro que contivesse elementos os quais facilitassem a transmissão do conhecimento dos conteúdos trabalhados em sala de aula. Isso não é diferente quando se trata de material didático de Cálculo para o ensino a distância.

Atualmente, enfatiza-se a função que o material didático tem no apoio ao ensino do professor-tutor como uma forma de transmissão do conhecimento científico a ser ensinado. Para isso, foi necessário explicitar o processo de produção de um material didático para cursos 
online, os quais costumam seguir padrões de design instrucional para se adequar ao públicoalvo a que estão destinados.

Logo, deve-se ter em mente sobre o conceito de design instrucional para compreender o seu papel nessa produção. O termo design tem sido entendido como um tipo concepção ao qual se faz referência a um produto que está envolvido no processo de construção, cujas características ou funções internas desse produto são colocadas em evidência, seja de forma cognitiva ou sensorial. Já o termo instrucional - cujo entendimento é tão complexo quanto o de design -, diz respeito à construção do conhecimento através da instrução para a formação de hábitos e comportamentos no sujeito, utilizando de uma “conversação inteligente", para que se possa adquirir compreensão do que está sendo aprendido com o ensino desse conhecimento (FILATRO, 2003).

Sendo assim, de acordo com Filatro (2008), o design instrucional pode ser definido como um processo (conjunto de atividades) de identificar um problema (uma necessidade) de aprendizagem e desenhar, implementar e avaliar uma solução para esse problema (FILATRO, 2008, p. 3). A partir dessa definição, pode-se entender o processo de produção de material didático que envolve minimamente a autoria/conteudista, o design instrucional, a revisão textual e a diagramação/grafismo.

Neste sentido, baseado nos estudos de Guedes (2011), apresentam-se os dois principais profissionais que trabalham com a produção de material didático para EaD: o professor-conteudista e o designer instrucional (DI). De acordo com a autora, o professorconteudista é o "responsável pela elaboração, criação intelectual do conteúdo e de todo o material didático voltado para as mídias web e impresso" que, juntamente com o DI, que é "responsável pela transição didática dos conteúdos", planeja a elaboração desse material didático, a fim de assegurar um caráter qualitativo a ele.

Para um curso de Licenciatura em Matemática semipresencial, o material didático deverá ser voltado a um público-alvo que "consumirá" esses materiais didáticos como apoio à sua aprendizagem durante todo o curso. No entanto, cabe aqui, também, o outro lado do processo que é o uso do material didático mediado pela tutoria. Saber como o professor-tutor “aplica" esses materiais e qual sua percepção sobre a qualidade didática e conceitual deles é o que se propõe investigar nessa pesquisa. 
Dessa forma, a responsabilidade de se elaborar um material didático de certa área do saber é de fundamental importância didático-pedagógica para facilitar e orientar a aprendizagem do aluno com o uso desse recurso didático. Por isso, cabe aqui o papel da transposição didática para facilitar essa transmissão do conhecimento do professor-tutor para o aluno com o uso desse material didático.

Sabe-se que a transposição didática trabalha com o campo epistemológico do professor quando trata de fazer o saber matemático fornecido na formação do professor de Matemática se transformar em saber ensinável. Nessa perspectiva, insere-se a metodologia de ensino Sequência FEDATHI, que foi percebida por Borges Neto e Santana (2003) como uma transposição didática e entendida por Souza (2013) como uma metodologia que trabalha com a postura do professor diante de um problema matemático com o aluno.

Souza ainda diz que, diante de um problema "o aluno deve reproduzir os passos que um matemático realiza quando se debruça sobre seus ensaios" (SOUZA, 2013, p. 18), para que assim ele possa ter uma experiência matemática significativa. Para isso, o professor deve percorrer, juntamente com aluno, quatro fases da sequência: Tomada de Posição; Maturação e Debruçamento; Solução; e Prova ${ }^{10}$. Também isso será investigado nessa pesquisa, quando se trata de saber se as necessidades de ensino do professor-tutor estão sendo atendidas com o uso do material didático de Cálculo I produzido e fornecido pela UAB/DEaD do IFCE, se está utilizando de uma metodologia de ensino, no caso a Sequência FEDATHI, para orientá-lo nessa transposição de saberes. A seguir, assinalam-se os procedimentos metodológicos que a pesquisa adotou.

\subsection{Procedimentos metodológicos}

O trabalho adota uma abordagem metodológica de pesquisa-ação, cujo método é indutivo, no qual se parte de um estudo particular de um objeto para se chegar a conclusões gerais (MEDEIROS, 2013). Com procedimentos de um estudo de caso com técnicas de coleta

\footnotetext{
${ }^{10}$ Essas quatro fases foram usadas como metodologia para embasar o questionário construído com o intuito de entrevistar os professores-tutores para saber se o material didático de Cálculo I estava adequado ao aluno que estuda a distância. Isso deve ser mais bem explicitado no capítulo 5 dessa pesquisa.
} 
de dados caracterizada pela observação direta e extensiva, foi utilizada como técnica a aplicação de um questionário.

De acordo com Belei et al (2008), a entrevista continua sendo, ainda, muito utilizada em pesquisas qualitativas. Ainda de acordo com as autoras, a utilização dessa técnica de investigação requer, por parte do pesquisador-entrevistador, um planejamento realizado com certa antecedência. Ele deve ter em mente que esse planejamento vai desde a seleção dos participantes à escolha do local a se realizar a entrevista.

As entrevistas que são utilizadas em pesquisas qualitativas são do tipo estruturada, semiestruturada e não estruturada. Nessa pesquisa, optou-se pela entrevista semiestruturada, na qual o pesquisador-entrevistador deve ser guiado por um roteiro de questões abertas, as quais lhe permitam uma organização flexível e mais extensa das perguntas à medida que as informações vão sendo apresentadas ao entrevistado (BELEI et al, 2008). Por fim, a seguir, tem-se uma breve visão dos capítulos desenvolvidos nessa pesquisa.

\subsection{Organização dos capítulos}

Essa pesquisa está organizada em seis capítulos. A introdução versa sobre o primeiro capítulo e, como observado, foi explicitada a contextualização, justificação, objetivos, referencial teórico e metodologia utilizada nessa pesquisa.

O segundo capítulo traz um panorama histórico do ensino de Cálculo no Brasil nas principais instituições de ensino superior: a Universidade Federal do Rio de Janeiro e a Universidade de São Paulo. O mesmo capítulo, também, faz uma análise comparativa de livros-textos utilizados nessas instituições.

No terceiro capítulo, discute-se sobre o material didático no âmbito da Educação a Distância, trazendo os conceitos como Design instrucional; Material didático digital e impresso. Ainda nesse capítulo, faz-se uma discussão sobre o material didático de Matemática para $\mathrm{EaD}$ e uma explanação do conceito de transposição didática, com o foco na Sequência FEDATHI. O capítulo ainda descreve características da transposição didática como uma 
técnica que contribui significativamente para a compreensão dos conteúdos relacionados à Matemática por parte do aluno.

O quarto capítulo evidencia o percurso metodológico da pesquisa. Descreve-se o material didático de Cálculo I que foi produzido para o curso de Licenciatura em Matemática semipresencial do IFCE. É descrito nesse capítulo também em que contexto foi aplicada essa pesquisa, os sujeitos investigados, o objeto de estudo, assim como também os instrumentos aplicados a esta investigação.

No capítulo posterior, o quinto, faz-se uma análise dos resultados para saber se o material didático da disciplina de Cálculo I do curso de Licenciatura em Matemática na modalidade semipresencial do IFCE atende às necessidades de ensino do professor-tutor através da análise das entrevistas realizadas com estes, para saber qual é a visão de cada professor-tutor com o uso desse material didático para ensinar aos seus alunos o conteúdo de Cálculo.

A conclusão explicitará como e em que medida os objetivos foram atingidos com a investigação realizada em todos os capítulos, assim como também apresentará os principais encaminhamentos. Por fim, seguem-se as referências, apêndices e anexos. 


\section{EXTRATOS HISTÓRICOS E A TRADIÇÃO DO USO DE LIVROS-TEXTOS NO ENSINO DE CÁLCULO NO BRASIL}

Esse capítulo descreve, sinteticamente, extratos da história do ensino de Cálculo no Brasil enfatizando os principais acontecimentos para a ocorrência do ensino de Matemática. Como elementos importantes para essa descrição, falar-se-á sobre as duas principais instituições de ensino superior do país do século XIX aos dias atuais: a Universidade Federal do Rio de Janeiro e a Universidade de São Paulo. O capítulo ainda versa sobre a tradição no uso de livros-textos utilizados nessas instituições de ensino superior. O objetivo do capítulo é entender a problemática do ensino dessa disciplina no contexto da pesquisa, inserindo o tema em seu cenário histórico.

\subsection{Breve retrospectiva do Ensino de Cálculo no Ensino Superior Brasileiro do século} XIX aos dias atuais

Para se entender a configuração do ensino de Cálculo, atualmente, nos cursos de graduações das universidades brasileiras nas áreas de engenharias, ciências exatas e da natureza (tanto em nível de bacharelado como de licenciatura), nas ciências administrativas, entre outros ramos em que o Cálculo se aplica, tem-se que, primeiramente, retroceder dois séculos na história do país para descrever a introdução do ensino superior no Brasil realizado através de implantação de duas instituições de ensino que, atualmente, tem notoriedade nacional, os quais foram: a Universidade Federal do Rio de Janeiro e a Universidade de São Paulo.

Vale ressaltar que essas duas instituições, a Universidade Federal do Rio de Janeiro e a Universidade de São Paulo, tiveram essa importância significativa no cenário, nos séculos XIX e XX, do ensino superior brasileiro. Ainda mais quando essas instituições foram as primeiras a ensinar Cálculo Avançado em seus cursos com objetivo de formar profissionais qualificados para servir ao poder colonialista e, posteriormente, republicano nesses dois períodos. É o que é explicado a seguir. 


\title{
2.1.1 Ensino de Cálculo na Universidade Federal do Rio de Janeiro
}

A breve retrospectiva começa a partir da chegada da família Real Portuguesa, em 1808, séc. XIX, quando, na fuga de Portugal, a família decidiu se instalar definitivamente no Brasil, mais especificamente na colônia do Rio de Janeiro. Com habitantes tão ilustres, o país teria que se adaptar aos recém-chegados 'novos moradores'. De acordo com Saviani (2010) e Lima (2012) amparado em Schwartzman (1979), com a necessidade de ter uma defesa militar na colônia do Rio de Janeiro, a Coroa Real Portuguesa se obrigou a adotar prioridades relacionadas a esse ponto e uma dela estava ligada à profissionalização de pessoas para servila, pois o Brasil era dotado de uma debilidade militar na defesa de suas fronteiras e em outros setores da sociedade.

Através de um documento datado de 4 de dezembro do ano 1810, o príncipe regente Dom João VI criou a Academia Real Militar ${ }^{11}$ naquela colônia com o intuito de treinar e formar oficiais de Artilharia, Engenheiros, Geógrafos e Topográficos (SCHWARTZMAN, 1979).

Observa-se que o currículo adotado na Academia Real Militar, para treinar e formar esses oficiais, era composto de diversas áreas do conhecimento, inclusive o matemático.

\begin{abstract}
O professor do Primeiro Ano ensinava aritmética, álgebra (até as equações de terceiro e quarto grau), geometria, trigonometria linear e elementos da trigonometria esférica; o professor do segundo ano ensinava álgebra avançada, geometria analítica, cálculo diferencial e integral; o professor do terceiro ano ensinava mecânica (estática e dinâmica), hidrostática e hidrodinâmica; e no quarto ano havia um professor de trigonometria esférica, ótica, astronomia e geodésia (CASTRO, 1955 apud SCHWARTZMAN, 1979, p. 13). (Grifo nosso)
\end{abstract}

O ensino de Cálculo era então visto por seus alunos somente no segundo ano de um curso dado na Academia Militar que tinha duração de sete anos. Segundo Schwartzman (1979), os conteúdos eram transmitidos de forma rígida e mecânica, pois o que importava era a aquisição de conhecimento, deixando claro que não havia espaço para dúvidas ou experimentações.

\footnotetext{
${ }^{11}$ Além da Academia Real Militar, criada em 1810, dois anos antes - no mesmo ano da vinda da família real portuguesa - o príncipe Dom João VI criou, no Rio de Janeiro, no Mosteiro de São Bento, a Academia Real de Marinha, considerada a primeira instituição técnica do Brasil (SCHWARTZMAN, 1979).
} 
De acordo com Lima (2012), a Academia Militar, nos primeiros trinta e dois anos, só foi frequentada por militares. Esse panorama mudou em 1833 com a permissão para cidadãos 'leigos' de frequentar aulas e fazer cursos nessa instituição. Ainda segundo o autor, a Academia Militar mudou de nome no decorrer dos tempos. Em 1839, ela passou a se chamar "Escola Militar", enquanto em 1855 uma repartição dessa escola foi criada e chamada de "Escola de Aplicação".

Em 1858, houve uma nova alteração e a instituição deixou a ser chamada de "Escola Militar" para ser chamada de "Escola Central”. Já a "Escola de Aplicação" passou a ser chamada de "Escola Militar e de Aplicação".

Em 25 de abril de 1874, através de um decreto imperial, a Escola Central foi transformada na Escola Politécnica do Rio de Janeiro. O currículo de ensino de matemática adotado antes desse período sofreu algumas alterações.

Nele, havia dois cursos: o 'Curso de Sciencias Physicas e Mathematicas' e 'Curso de Sciencias Physicas e Naturaes', o qual naquele se visualizava a presença do Cálculo Diferencial e Integral, como visto na ementa dos conteúdos abordados em cada ano a seguir:

\footnotetext{
$1^{\circ}$ ano: Álgebra, Trigonometria Plana, Geometria Analítica, Física Experimental, Meteorologia, Desenho Linear, Topográfico e de Paisagem;

$2^{\circ}$ ano: Geometria Descritiva, Cálculo Infinitesimal, Cálculo das Probabilidades, das Variações e Diferenças Finitas, Química, Desenho Descritivo e Topográfico; $3^{\circ}$ ano: Mecânica Racional e Aplicada às Máquinas em Geral, Máquinas a Vapor e suas Aplicações, Mineralogia, Geologia e Desenho de Máquinas;

$4^{\circ}$ ano: Trigonometria Esférica, Ótica, Astronomia, Geodésia, Botânica, Zoologia e Desenho Geográfico. (LIMA, 2012, p. 75-76). (Grifo nosso)
}

É importante saber que, de 1810 a 1875, o Rio de Janeiro era a única colônia que sediava o ensino superior de Matemática no Brasil. Isso lhe deu o título de "pioneiro no ensino de Matemática em nível superior” (LIMA, 2012, p. 76) nessa época.

Foram expostos até aqui recortes da história do ensino de superior e de Cálculo no Brasil Colônia. Adentrando a era republicana, pode-se falar sobre os avanços do ensino superior no que diz respeito à criação de universidades, marco importante na história educacional brasileira.

No ano de 1920, em 7 de setembro, no governo de Epitácio Pessoa, foi instituída, através do decreto de $\mathrm{n}^{\circ}$ 14.343, a Universidade do Rio de Janeiro (URJ) como sendo a 
reunião das diversas escolas existentes na época, como a Escola Politécnica; a Faculdade de Medicina; e a Faculdade de Direito, todas as três criadas ainda no império e que, de certa forma, seguiam o modelo de cada unidade agregada (BRASIL, 1920).

Já em 5 de julho de 1937, no governo de Getúlio Vargas, foi criada a Universidade do Brasil (UBr), através da lei $\mathrm{n}^{0} 452$, de 5 de julho de 1937, que dava continuidade à Universidade do Rio de Janeiro ${ }^{12}$ criada na década de vinte (BRASIL, 1937).

Sabe-se que a UBr era uma reunião de escolas superiores existentes na cidade naquela época, e no caput do $2^{\mathrm{a}}$ artigo do Capítulo I, sobre as finalidades da UBr, enfatiza-se “o desenvolvimento da cultura, filosófica, científica, literária e artística" (BRASIL, 1937), mas, na prática, havia uma certa prioridade para a formação técnica de profissionais para os diversos ramos da sociedade brasileira.

Para a formação desses profissionais, foram criados e incorporados setores de ensino em diversas áreas na UBr, como a Faculdade Nacional de Filosofia, Ciências e Letras; a Faculdade Nacional de Educação; Escola Nacional de Engenharia; Escola Nacional de Minas e Metalurgia; Escola Nacional de Química; Faculdade Nacional de Medicina; Faculdade Nacional de Odontologia; Faculdade Nacional de Farmácia; Faculdade Nacional de Direito; Faculdade Nacional de Política e Economia; Escola Nacional de Agronomia; Escola Nacional de Veterinária; Escola Nacional de Arquitetura; Escola Nacional de Belas Artes; Escola Nacional de Música (ver a lei citada no trecho anterior).

Através do decreto-lei $\mathrm{n}^{\circ} 1.190$ de 4 de abril de 1939, foi instituída na UBr a Faculdade Nacional de Filosofia (FNFi), a qual era constituída dos seguintes cursos: Matemática, Física, Química, História Natural, Ciências Sociais, Letras Clássicas, Letras Neolatinas, Letras Anglo Germânicas, Filosofia e Pedagogia (BRASIL, 1939).

O curso de Matemática era um setor da FNFi que foi dividido em três anos com disciplinas que conferiam o caráter formativo do profissional dessa área, o bacharel em Matemática. Observa-se que essa foi a primeira vez que o Governo Brasileiro investiu na formação de bacharéis em Matemática, criando-se um curso próprio para esse fim, e não

\footnotetext{
${ }^{12}$ Para um marco histórico lógico e conciso, essa não foi a primeira universidade do país e sim a Universidade de São Paulo que foi conhecida assim por, justamente, ter um caráter de universalidade e cientificidade que se esperava ter para a construção e solidificação de uma universidade. O que não ocorria com a Universidade do Rio de Janeiro, pois, sua função estava mais voltada para formação de profissionais técnicos em diversos setores da sociedade do país.
} 
como um curso incorporado na formação de um profissional de engenharia como acontecia anteriormente.

A distribuição das disciplinas para o curso de Bacharelado em Matemática foi realizada da seguinte forma:

- Primeiro ano: Análise matemática; Geometria analítica e projetiva; Física geral e experimental.

-Segundo ano: Análise matemática; Geometria descritiva e complementos de geometria; Mecânica racional; Física geral e experimental.

- Terceiro ano: Análise superior; Geometria superior; Física matemática; Mecânica celeste.

Nota-se que a presença do Cálculo Diferencial e Integral se encontrava nos dois primeiros anos na disciplina de "Análise Matemática", na qual se trabalhava os mesmos conceitos de Cálculo, mas no nível de rigor algébrico avançado.

A influência da FNFi foi, significativamente, importante para o desenvolvimento de outras universidades brasileiras. A título de exemplo, isso pode ser verificado no atual Projeto Pedagógico do curso de bacharelado em Matemática da Universidade Federal do Ceará (UFC), o qual menciona que esse curso foi criado segundo o modelo da FNFi criado naquela época (BRASIL, 1961).

Para finalizar o percurso histórico dessa instituição que foi de importância para o ensino superior brasileiro, em específico para a difusão do ensino de Cálculo, em 20 de agosto de 1965, no governo de Castelo Branco, a UBr passou a se chamar Universidade Federal do Rio de Janeiro (UFRJ), através da lei $\mathrm{n}^{\circ} 4.759$, mantendo as mesmas unidades de ensino (BRASIL, 1965).

Atualmente, o curso de Matemática da UFRJ é realizado em quatro anos, dividido em oito períodos. O curso oferece disciplinas obrigatórias e optativas. Entre as obrigatórias, está o Cálculo Diferencial e Integral dividido, didaticamente, em três níveis. 
A matriz curricular ${ }^{13}$ desse curso atende à necessidade de formar um matemático para uma das três subáreas que necessitam da Matemática Avançada: Matemática Pura; Matemática Computacional; e Matemática Estatística.

Até aqui, aludiu-se sobre fatos históricos relacionados à UFRJ, analisando-se, sempre que possível, o tratamento que era dado ao ensino de Cálculo nessa instituição de ensino superior. Em outras regiões do país, foram criadas outras escolas de formação em nível superior. Inclusive em São Paulo, no final do séc. XIX, foi fundada outra instituição de relativa importância para a disseminação e cultura do ensino de Cálculo, que também tinha como um dos setores, que lhe foi agregado, a Escola Politécnica. Isso será exposto a seguir.

\subsubsection{Ensino de Cálculo na Universidade de São Paulo}

Para se falar da história da Universidade de São Paulo (USP) deve-se, primeiramente, dar um parêntese na história da criação da Escola Politécnica de São Paulo, o qual foi criada através da lei $\mathrm{n}^{\circ} 191$ de 24 de agosto de 1893, ainda no império, sob a direção de Antônio Francisco de Paula Souza, na função de diretor; e de Luiz Anhaia Mello, como vice-diretor. Os primeiros cursos dessa Escola foram criados para formar profissionais nas áreas de Engenharia Civil, Industrial e Agrícola, além de haver um curso de Artes Mecânicas (BRASIL, 1893).

Segundo o Capítulo I dessa lei, as engenharias civil e industrial tinham duração de cinco anos cada uma e a presença do ensino de Cálculo se dava nos dois primeiros anos para a Engenharia Civil e somente no primeiro ano para a Engenharia Industrial.

Já no início do século XX, movimentos pela reforma universitária eclodiram em na capital de São Paulo. De acordo com Lima (2012), um movimento chamado "Campanha pela Universidade", constituído por intelectuais brasileiros daquela época, lutou pela reforma universitária, luta essa que culminou na criação da primeira universidade do Brasil.

\footnotetext{
${ }^{13}$ Para mais detalhes, acessar: https://si3.ufc.br/sigaa/public/curso/curriculo.jsf.
} 
Foi no governo de Getúlio Vargas que foi criada a USP, através do Decreto $\mathrm{N}^{\circ}$ 6.283, de 25 de janeiro de 1934, a primeira em caráter de universalidade e cientificidade para formação acadêmica universitária de um cidadão brasileiro (BRASIL, 1934).

A Escola Politécnica de São Paulo foi uma unidade o qual foi agregada a USP, mas, além dessa, a USP contava com as seguintes unidades em funcionamento: Faculdade de Direito; Faculdade de Medicina; Faculdade de Farmácia e Odontologia; Instituto de Educação; Faculdade de Filosofia, Ciências e Letras; Instituto de Ciências Econômicas e Comerciais; Escola de Medicina Veterinária; Escola Superior de Agricultura "Luiz de Queiroz"; Escola de Belas Artes. Foi justamente na Faculdade de Filosofia, Ciências e Letras (FFCL) da universidade que o curso de Matemática foi instituído.

A FFCL era uma unidade de ensino dividida em três secções: Filosofia, Ciências e Letras. A secção de Ciências era subdividida em Ciências Matemáticas, Ciências Físicas, Ciências Químicas, Ciências Naturais, Geografia e História, Ciências Sociais e Políticas. A unidade de Ciências Matemáticas tinha como disciplinas Geometria; História das Matemáticas; Análise matemática; Cálculo Vetorial e Elementos da Geometria Infinitesimal; Mecânica Racional e Elementos de Mecânica Celeste (BRASIL, 1934).

Atualmente, o curso de Matemática da USP é realizado em quatro anos e é dividido em oito semestres. Assim como no curso dado no UFRJ, a USP oferece disciplinas obrigatórias e optativas. Como poderia se esperar, entre as obrigatórias, tem-se a presença do Cálculo Diferencial e Integral, também dividido didaticamente em quatros níveis de ensino.

A matriz curricular ${ }^{14}$ desse curso atende à necessidade de formar um matemático puro. Diferentemente da UFRJ, onde o aluno deve escolher no decorrer do curso qual área seguir, na USP o curso de Matemática e suas áreas afins é separado logo no início, cabendo ao candidato escolher o curso na seleção de admissão.

A presença da disciplina de Cálculo nos cursos para se formar desde os engenheiros (no império) aos matemáticos puros e aplicados (na república), verificou-se qual tipo de livro-texto era utilizado como base para o ensino de Cálculo. Deste modo, a seguir, apresentam-se alguns livros-textos utilizados e se compara as abordagens dos conceitos advindos do Cálculo.

${ }^{14}$ Para mais detalhes, acessar:

https://uspdigital.usp.br/jupiterweb/listarGradeCurricular?codcg=45\&codcur=45031\&codhab $=1 \&$ tipo $=\mathrm{N}$ 
2.2 Análises de amostras de livros-textos de Cálculo adotados nas Instituições de Ensino Superior Brasileira

O uso dos livros-textos para ensinar Cálculo Avançado aos alunos de ensino superior tem sua tradição respaldada nas grandes obras matemáticas europeias. Pode-se observar que esses livros-textos utilizados nas instituições de ensino superior, tanto da Academia Real Militar do Rio de Janeiro como da Escola Politécnica de São Paulo, no período entre 1808 e 1932, eram grandes compêndios de ideias matemáticas desenvolvidas até aquela época por matemáticos europeus.

Figura 1 - À esquerda a capa do livro de Lacroix $^{15}$; e à direita a capa do livro de Sonnet ${ }^{16}$.

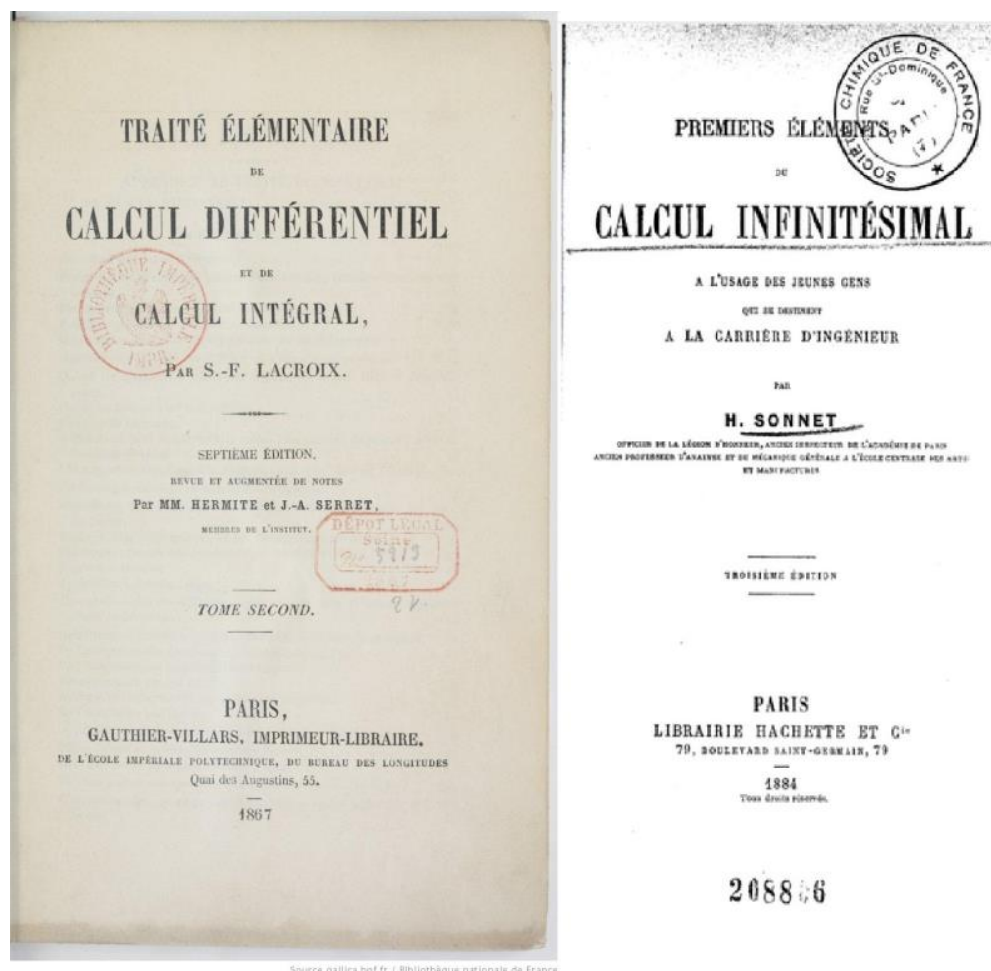

Fontes: Lacroix (1897) e Sonnet (1884).

Pesquisas como de Oliveira (2006), Ziccardi (2009) e Lima (2012) recordam que, entre as influências europeias, no que diz respeito aos livros utilizados pela Academia Real Militar do Rio de Janeiro, um dos livros de Cálculo Diferencial e Integral adotado foi uma tradução de uma obra francesa que se chamava Traité Elémentaire de Calcul Différentiel et de

\footnotetext{
${ }^{15}$ foi extraída do site: http://gallica.bnf.fr/ark:/12148/bpt6k6292302n

${ }^{16}$ foi extraído do site: http://gallica.bnf.fr/ark:/12148/bpt6k91919z
} 
Calcul Intégral $^{17}$, de um matemático francês chamado Sylvestre François Lacroix. Observa-se na Figura 1 (à esquerda) a representação da capa desse livro.

Segundo Lima (2012), a tradução desse livro não era didática e sim uma reprodução fiel do livro original. Esse livro estava mais para um compêndio de ideias matemáticas desenvolvidas naquela época pelos matemáticos europeus do que o ensino de Cálculo para os alunos de ensino superior.

O objetivo principal desse livro era apresentar as principais ideias relativas ao Cálculo. Ele estava dividido em duas grandes áreas: o cálculo diferencial e o integral. Esse livro tanto não abordava as noções intuitivas dos conceitos relativos às duas áreas, como não explicava o significado das notações adotadas por ele.

No entanto, entre as obras adotadas pela Escola Politécnica de São Paulo, o livro chamado Premiers Éléments du Calcul Infinitesimal (ver Figura 1, à direita), do matemático europeu Hyppolite Sonnet, foi uns dos livros adotados nessa instituição. O principal embasamento dele se dava nas ideias desenvolvidas naquela época por dois matemáticos ilustres: Isaac Newton e Gottfried Leibniz (LIMA, 2012). As principais ideais desenvolvidas por Newton e Leibniz foram reproduzidas no livro de Sonnet e logo depois foram utilizadas nos cursos da Politécnica de São Paulo. Elas se pautavam na ênfase dada aos infinitésimos e à noção intuitiva de limite.

No Quadro 1, podem-se verificar as principais diferenças entre os livros adotados nessas duas principais instituições no período de 1808 a 1932. As abordagens realizadas sobre os conceitos de Função, Limites, Derivadas e Integrais tem suas particularidades apresentadas pelos autores de cada livro.

Quadro 1 - Comparação entre livros-textos adotados ou traduzidos e as abordagens dos conceitos de Cálculo nas duas principais instituições de ensino superior do Brasil entre 1808 a 1932.

\begin{tabular}{|c|c|c|}
\hline $\begin{array}{c}\text { Academia Real Militar do Rio } \\
\text { de Janeiro }\end{array}$ & $\begin{array}{c}\text { Escola Politécnica de São } \\
\text { Paulo }\end{array}$ \\
\hline
\end{tabular}

\footnotetext{
${ }^{17}$ Segundo Lima (2012), a tradução desse livro foi realizada por um professor da Academia Militar chamado de Francisco Cordeiro da Silva Torres Alvin. Este livro foi, também conhecido por "Pequeno Lacroix", o primeiro livro-texto de Cálculo Diferencial e Integral traduzido para o Português aqui no Brasil. Sabe-se que o Pequeno Lacroix é uma versão simplificada de outra obra de Lacroix, o "Traité du Calcul Différentiel et du Calcul Intégral", conhecido por "Grande Lacroix".
} 


\begin{tabular}{|c|c|c|}
\hline $\begin{array}{c}\text { Livro-texto } \\
\text { adotado ou } \\
\text { traduzido }\end{array}$ & $\begin{array}{l}\text { A tradução do livro de François } \\
\text { Lacroix: "Traité Elémentaire de } \\
\text { Calcul Différentiel et de Calcul } \\
\text { Intégral". }\end{array}$ & $\begin{array}{l}\text { Livro adotado foi do } \\
\text { matemático Hyppolite Sonnet: } \\
\text { "Premiers Éléments du Calcul } \\
\text { Infinitesimal". }\end{array}$ \\
\hline $\begin{array}{c}\text { Abordagem no } \\
\text { conceito de } \\
\text { Funções }\end{array}$ & $\begin{array}{l}\text { Não há uma apresentação } \\
\text { definida de função. }\end{array}$ & $\begin{array}{l}\text { A função é vista como uma } \\
\text { expressão analítica. }\end{array}$ \\
\hline $\begin{array}{c}\text { Abordagem no } \\
\text { conceito de } \\
\text { Limites }\end{array}$ & $\begin{array}{l}\text { Não há uma definição do } \\
\text { conceito de limites. Somente } \\
\text { uma citação na abordagem do } \\
\text { conteúdo de derivadas. }\end{array}$ & $\begin{array}{l}\text { Somente uma definição retórica } \\
\text { na abordagem desse conceito. } \\
\text { Abordava, intuitivamente, o } \\
\text { conceito de limites através da } \\
\text { ideia de infinitésimos. }\end{array}$ \\
\hline $\begin{array}{c}\text { Abordagem no } \\
\text { conceito de } \\
\text { Derivadas }\end{array}$ & $\begin{array}{l}\text { Aqui há regras e procedimentos } \\
\text { de manipulação algorítmica de } \\
\text { derivadas. }\end{array}$ & $\begin{array}{l}\text { A derivada não é uma ideia } \\
\text { muito explorada, sendo mais } \\
\text { bem compreendida através de } \\
\text { definições e ideias. Há a } \\
\text { apresentação teórica dos } \\
\text { conceitos relativos à derivação } \\
\text { pautada nos dois métodos } \\
\text { desenvolvidos até aquela época: } \\
\text { Leibniz e Newton. }\end{array}$ \\
\hline $\begin{array}{c}\text { Abordagem no } \\
\text { conceito de } \\
\text { Integrais }\end{array}$ & $\begin{array}{l}\text { Igualmente à derivada, só há } \\
\text { uma apresentação de técnicas } \\
\text { algorítmicas para se resolver } \\
\text { integrais. Enfatiza-se que havia } \\
\text { uma explicação de que derivada } \\
\text { e integral são operações inversas } \\
\text { uma da outra. }\end{array}$ & $\begin{array}{l}\text { Traz uma abordagem } \\
\text { diferenciada, pois o conceito de } \\
\text { integral foi introduzido e } \\
\text { desenvolvido através de estudos } \\
\text { de áreas de figuras geométricas. } \\
\text { Há, também, a predominância } \\
\text { da informação de que derivada e } \\
\text { integral são operações inversas. }\end{array}$ \\
\hline
\end{tabular}

Fontes: Oliveira (2006), Ziccardi (2009) e Lima (2012).

Observa-se que, enquanto no livro de Lacroix não há um definição de função que é base para os outros conceitos de Cálculo -, em Sonnet se faz uma abordagem analítica 
desse conceito (isso também ocorre para o conceito de Limites). Para o conceito de Derivada, em Lacroix, há somente presença de manipulações algorítmicas, atendo-se apenas aos cálculos aritméticos. Enquanto isso, Sonnet fazia uma abordagem em cima desse conceito na perspectiva de Leibniz e Newton. Já o conceito de Integral desenvolvida na obra de Lacroix, assim como o conceito de derivada, era abordado de forma mecânica com repetições de regras e procedimentos algoritmos.

Na obra de Sonnet, ainda para o conceito de integral, abordava-se o assunto de áreas de figuras geométricas aos quais se desenvolveria esse conceito. De acordo com Oliveira (2006), uma característica que predominou na obra de Sonnet foi que “(...) Os objetivos de Sonnet, manifestados em seu prefácio, não são teóricos, o que reduz sua obra aos exercícios mecânicos e às aplicações imediatas. Não há espaço para a criatividade" (OLIVEIRA, 2006, p. 68).

Vale ressaltar, porém, que as grades curriculares do ensino de Cálculo nessas duas instituições, tanto da Academia Real Militar do Rio de Janeiro como da Escola Politécnica de São Paulo, tinham como principal objetivo formar profissionais da área militar e das engenharias. Esses profissionais, ao final de sua formação, tinham que estar aptos a utilizar as habilidades adquiridas no curso e aplicar no seu cotidiano às 'ferramentas' que aprenderam com a Matemática de nível superior.

Os conceitos apresentados pela Matemática desse nível de ensino não trabalhavam o lado prático do conteúdo. Daí se pode ver que a obra de Sonnet foi adotada pela Politécnica de São Paulo para atender às "aplicações imediatas" do estudo, uma vez que esse conteúdo era, basicamente, a transmissão de regras de processo algoritmos de derivação e integração.

A tradição de usar livros europeus foi sendo superada no decorrer do tempo pelas universidades. Na busca de obter informações sobre outros livros-textos de Cálculo usados em diferentes épocas por essas instituições de ensino superior, apresenta-se a seguir quais obras e autores estão sendo usadas desde anos de $1970^{18}$ aos dias atuais. Na pesquisa bibliográfica dessas obras, verificou-se que há presença de outros livros-textos de Cálculo de origem norte-americana e, também, de origem brasileira utilizados nessas mesmas

\footnotetext{
${ }^{18}$ A base para citação desse ano foi apoiada de acordo com os anos de produção das obras que surgiram nessa época sobre o estudo de Cálculo, utilizando-se da data de primeira edição de cada livro.
} 
universidades estudadas nesse capítulo. É o caso dos três livros apresentados na Figura 2 dos autores Louis Leithold; Hamilton Guidorizzi; e James Stewart.

Figura 2 - À esquerda a capa do livro de Louis Leithold, no centro a capa do livro de Halmilton Guidorizzi e à direita a capa do livro de James Stewart.

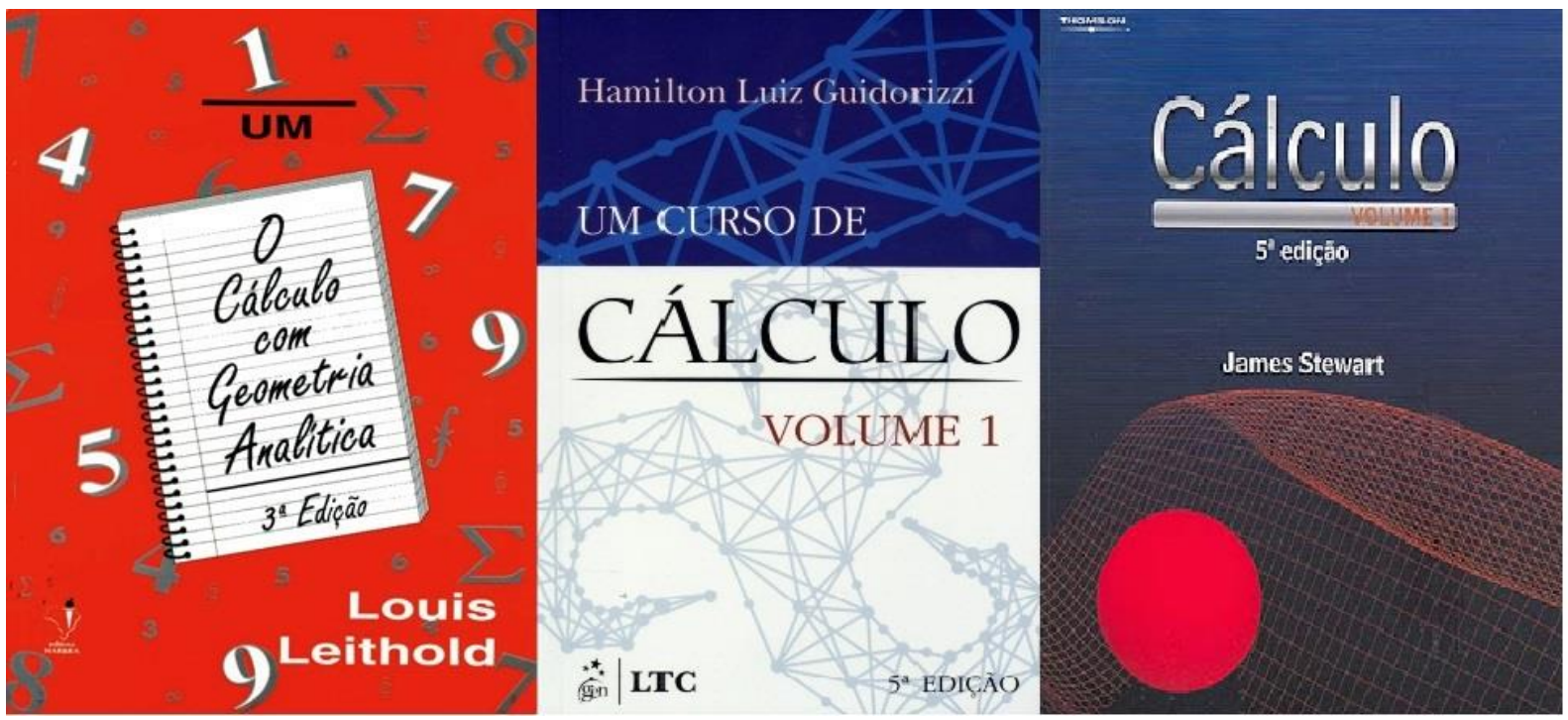

Fontes: As imagens das capas foram extraídas de Leithold $(1994)^{19}$; Guidorrizi $(1997)^{20}$; e Stewart $(2006)^{21}$.

Atualmente, essas duas instituições de ensino superior são conhecidas, respectivamente, por UFRJ e a USP. Em suas grades curriculares dos cursos de Matemática, pode-se notar a presença dos livros-textos de Cálculo desses três autores citados (os quais se pôde ver uma reprodução das capas desses livros na Figura 2). Tanto a UFRJ como a USP utilizam no curso de Matemática (bacharelado e licenciatura) esses três livros em sua bibliografia básica ${ }^{22}$. No Quadro 2, observam-se as comparações das abordagens dos conceitos de Função, Limite, Derivadas e Integrais que são tratados em cada livro e que são explicitadas por seus autores nos seus prefácios.

\footnotetext{
${ }^{19}$ Foi extraída do site: http://harbra.com.br/images/produtos/OCalculocomGeometriaAnalitica-3-aedicaoVolume1-4367.jpg

${ }^{20}$ Foi extraído do site: https://ldp.admdistribuidora.com.br/images/8521612591Peq.jpg

${ }^{21}$ Foi extraída do site: http://mayraclara.mat.br/mat_did/calculo1/james_stewart1.pdf

${ }^{22}$ Isso pode ser verificado na grade curricular do curso de Matemática da UFRJ, no qual se encontra a ementa, o conteúdo programático e essa bibliográfica recomendada. Acessar site: http://www.im.ufrj.br/bacharelado/ Ementa da disciplina do bacharelado e m Matemática da USP pode ser visto no site https://uspdigital.usp.br/jupiterweb/obterDisciplina?sgldis=MAT0111\&codcur=45031\&codhab=1. Ementa da disciplina da licenciatura em Matemática da USP pode ser vista no site https://uspdigital.usp.br/jupiterweb/obterDisciplina?sgldis=MAT1351\&codcur=45024\&codhab=1.
} 
Quadro 2 - Comparação entre livros-textos adotados ou traduzidos atualmente por diversas instituições de ensino superior entre 1970 aos dias de hoje.

\begin{tabular}{|c|c|c|c|}
\hline & $\begin{array}{c}\text { "O Cálculo com } \\
\text { Geometria Analítica" } \\
\text { Louis Leithold }\end{array}$ & $\begin{array}{c}\text { "Um curso de } \\
\text { Cálculo" } \\
\text { Hamilton Guidorizzi }\end{array}$ & $\begin{array}{c}\text { “Cálculo" } \\
\text { James Stewart }\end{array}$ \\
\hline $\begin{array}{c}\text { Abordagem no } \\
\text { conceito de } \\
\text { Funções }\end{array}$ & $\begin{array}{l}\text { Faz uma breve revisão } \\
\text { sobre o assunto de } \\
\text { tópicos da Geometria } \\
\text { Analítica. Também } \\
\text { revisa e discute o } \\
\text { conceito de função } \\
\text { enfatizando suas } \\
\text { operações e } \\
\text { propriedades. Explora } \\
\text { os vários tipos de } \\
\text { funções } \\
\text { trigonométricas. }\end{array}$ & $\begin{array}{l}\text { De forma sucinta, o } \\
\text { livro traz uma } \\
\text { abordagem teórica de } \\
\text { funções e suas } \\
\text { especificações com } \\
\text { uma abordagem mais } \\
\text { algébrica do que } \\
\text { geométrica. }\end{array}$ & $\begin{array}{l}\text { Há presença de estudo } \\
\text { dos vários tipos de } \\
\text { funções com } \\
\text { abordagem verbal, } \\
\text { numérica, visual e } \\
\text { algébrica. }\end{array}$ \\
\hline $\begin{array}{c}\text { Abordagem no } \\
\text { conceito de } \\
\text { Limites }\end{array}$ & $\begin{array}{l}\text { Faz tanto uma } \\
\text { introdução intuitiva da } \\
\text { noção de limite, assim } \\
\text { como uma boa } \\
\text { exploração desse } \\
\text { conceito nas formas } \\
\text { algébrica, aritmética e } \\
\text { geométrica. Há } \\
\text { presença de várias } \\
\text { propriedades e } \\
\text { exemplos. }\end{array}$ & $\begin{array}{l}\text { O conceito de limite é } \\
\text { introduzido através de } \\
\text { exemplos depois que } \\
\text { se tem uma explicação } \\
\text { intuitiva de } \\
\text { continuidade. Há } \\
\text { apresentação resumida } \\
\text { de regras } \\
\text { (propriedades) que } \\
\text { envolvem limites de } \\
\text { funções. }\end{array}$ & $\begin{array}{l}\text { O conceito de limite de } \\
\text { uma função é tratado } \\
\text { de forma que o leitor } \\
\text { tenha uma visão das } \\
\text { ideias de tangente e } \\
\text { velocidade através do } \\
\text { ponto de vista descrito, } \\
\text { gráfico, numérico e } \\
\text { algébrico. }\end{array}$ \\
\hline $\begin{array}{c}\text { Abordagem no } \\
\text { conceito de } \\
\text { Derivadas }\end{array}$ & $\begin{array}{l}\text { A derivada é } \\
\text { apresentada e } \\
\text { introduzida através da } \\
\text { interpretação } \\
\text { geométrica da reta }\end{array}$ & $\begin{array}{l}\text { O conceito de derivada } \\
\text { é apresentado de uma } \\
\text { interpretação } \\
\text { geométrica para logo } \\
\text { depois ser realizada }\end{array}$ & $\begin{array}{l}\text { A derivada é tratada } \\
\text { sob um aparato gráfico } \\
\text { e numérico com } \\
\text { exploração das regras } \\
\text { de diferenciação e suas }\end{array}$ \\
\hline
\end{tabular}




\begin{tabular}{|c|c|c|c|}
\hline & $\begin{array}{l}\text { tangente a uma curva } \\
\text { para logo ser definida } \\
\text { formalmente. Há } \\
\text { presença de conceitos } \\
\text { da Física para } \\
\text { aplicações da derivada. } \\
\text { Há, ainda, os vários } \\
\text { tipos de derivadas de } \\
\text { funções especiais: } \\
\text { trigonométricas, } \\
\text { logarítmicas, } \\
\text { exponenciais, entre } \\
\text { outros. A construção } \\
\text { de gráficos, usando-se } \\
\text { o conceito de derivada, } \\
\text { que é bem explorada } \\
\text { através dos exemplos. }\end{array}$ & $\begin{array}{l}\text { uma definição formal. } \\
\text { Há apresentação de } \\
\text { derivadas de vários } \\
\text { tipos de funções. }\end{array}$ & $\begin{array}{l}\text { aplicações em diversas } \\
\text { áreas. O estudo do } \\
\text { conceito de derivada } \\
\text { nesse livro é } \\
\text { enfatizado no } \\
\text { tratamento gráfico das } \\
\text { funções que são } \\
\text { diferenciáveis. }\end{array}$ \\
\hline $\begin{array}{c}\text { Abordagem no } \\
\text { conceito de } \\
\text { Integrais }\end{array}$ & $\begin{array}{l}\text { Introduz o conceito de } \\
\text { integral se utilizando } \\
\text { do termo } \\
\text { "antidiferenciação" em } \\
\text { vez de "integral } \\
\text { indefinida". Explora, } \\
\text { intuitivamente, a } \\
\text { noção de integral, } \\
\text { definida como sendo o } \\
\text { limite das somas. } \\
\text { Utiliza-se de } \\
\text { procedimentos } \\
\text { numéricos para } \\
\text { adequação em } \\
\text { calculadoras e } \\
\text { computadores. }\end{array}$ & $\begin{array}{l}\text { Há uma apresentação } \\
\text { do conceito de } \\
\text { primitivas para logo } \\
\text { depois se definir uma } \\
\text { integral formalmente. } \\
\text { Há apresentação de } \\
\text { algumas propriedades } \\
\text { e alguns } \\
\text { procedimentos sobre } \\
\text { técnicas de integração. }\end{array}$ & $\begin{array}{l}\text { Desenvolve-se o } \\
\text { conceito de integral } \\
\text { através das ideias de } \\
\text { áreas e distâncias, com } \\
\text { uso de notação } \\
\text { somatória. A integral é } \\
\text { explicada em vários } \\
\text { contextos, } \\
\text { principalmente com o } \\
\text { uso de valores } \\
\text { tabulados em gráficos } \\
\text { e tabelas. A exploração } \\
\text { desse conceito se dá } \\
\text { através das técnicas de } \\
\text { integração e aplicações } \\
\text { da integral. }\end{array}$ \\
\hline
\end{tabular}




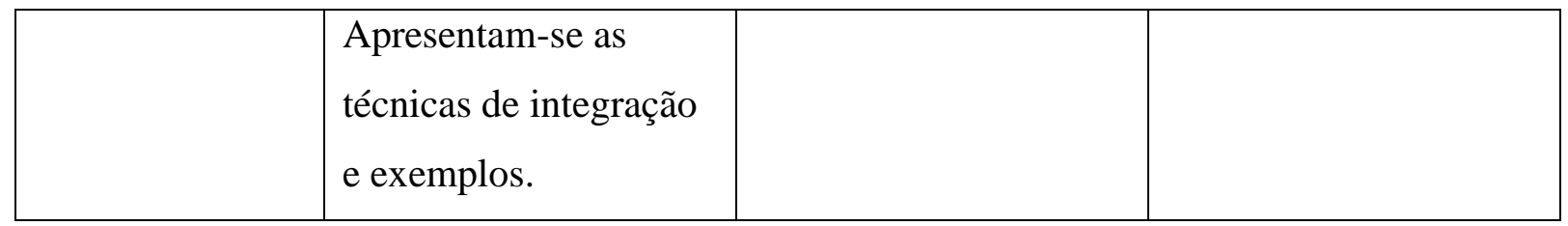

Fontes: Leithold (1994), Guidorrizi (1997) e Stewart (2006).

Vale ressaltar aqui que o objetivo em cada livro-texto é diferente, pois, no prefácio, cada autor abordou esses conceitos com base no que eles acreditavam ser importantes. A começar pelo Leithold (1994) que falava que as explanações seriam feitas "passo-a-passo", com inúmeros exemplos para o estudante tomar como modelo. Ele explica que a presença de demonstrações em quase todos os teoremas é importante para que haja a maturidade intelectual do aluno. A produção desse livro foi realizada com o objetivo de ser uma base para futuros matemáticos assim como para engenheiros.

Já Guidorizzi (1997) explicava que o livro tinha sido desenvolvido para alunos da Politécnica e Instituto de Matemática da USP e, também, para os alunos do Instituto de Engenharia Paulista. O mesmo autor ainda enfatizava que os conceitos e teoremas eram quase todos apresentados por uma motivação geométrica e física, e que as demonstrações dos teoremas de alguns conceitos não seriam todos apresentados e se encontrariam no final do livro.

O livro do Stewart (2006) relata em seu prefácio a importância de se focalizar a compreensão formal dos conceitos através de exploração algébrica, geométrica e aritmética. Ainda tenta dar sentido aos conceitos explorados através de sua aplicação prática, o que foi um diferencial em comparação com os dois outros livros.

Esse capítulo foi desenvolvido com o intuito de apresentar as principais ações sobre o ensino de Cálculo no seu breve contexto histórico. Essa última parte versou sobre os livros-textos utilizados nas intuições de ensino superior a fim de se poder compreender em que se baseava o ensino dessa área da Matemática Avançada. Cabe ressaltar, todavia, que os cursos ministrados nessas instituições citadas eram totalmente presenciais. Logo, a preocupação com a abordagem didática dos conceitos trabalhados não era uma das prioridades dos autores desses livros.

O intuito de fazer essa análise comparativa dos conceitos que cada um desses livros, principalmente do Quadro 2, está relacionado à bibliografia básica que é apontada no 
Programa de Unidade Didática da disciplina de Cálculo I do curso de Licenciatura em Matemática semipresencial do IFCE (como poderá ser visto no Anexo I no final desse trabalho, o qual será usado para análise posterior).

Assim, justamente por se estar trabalhando com um curso semipresencial, pode-se entender que, com a popularização dos computadores pessoais e a propagação e democratização da internet, o ensino de Cálculo ganhou um novo espaço para sua disseminação. Assim sendo, a abordagem didática dessa área do saber passou de uma preocupação secundária para ser uma das características importantes na elaboração de um livro didático.

Diante disso, o próximo capítulo, o terceiro, foca diretamente sobre essa abordagem didática, discutindo sobre o conceito de Material Didático de Matemática para nível superior no âmbito da Educação a Distância online, o qual tem peculiaridades próprias de sua elaboração e produção, não podendo ser somente mais uma (re)produção de um livrotexto de Cálculo como o que se encontra para os cursos superiores presenciais. 


\section{MATERIAL DIDÁTICO DE MATEMÁTICA NA EDUCAÇÃO A DISTÂNCIA}

Nesse capítulo, apresentar-se-á o Material Didático (MD) no contexto da Educação a Distância (EaD). Ele será enfatizado como um recurso educacional entendido do ponto de vista do Design Instrucional Contextualizado. Serão descritos os principais atores do processo de produção do MD: o Designer Instrucional e o professor-conteudista. Ainda será feita uma discussão em torno de conceitos, das classificações, das características estruturais e pedagógicas de um MD para ensino a distância. Em uma segunda abordagem, será apresentado o conceito de transposição didática e o seu papel na metodologia de ensino Sequência FEDATHI, para que assim se possa nortear a ideia-chave desse capítulo: o MD de Matemática para EaD na visão do professor-tutor, sua aplicação no uso desse recurso didático, com o aluno no intuito de averiguar sua adequabilidade ao ensino de Cálculo na aprendizagem remota.

\subsection{O Design Instrucional na Produção de Material Didático para EaD}

Em qualquer obra que se estude sobre $\mathrm{EaD}$ e suas origens, pode-se observar três fases distintas, em que são explicitadas em autores como Moore e Kearsley (2007), Corrêa (2007) e Moreira (2009). A primeira fase abordada por esses autores foi marcada pela presença do ensino por correspondência e o único recurso didático educacional se dava por meio de livros impressos enviados pelo correio aos cursistas que desejavam se profissionalizar.

A segunda fase, em que o ensino era concebido através da transmissão via rádio e televisão, tinha-se a presença de outros recursos didáticos, tais como videoteipes e teleconferências para a transmissão do conhecimento a ser aprendido.

Já a terceira e última fase trata de quando a $\mathrm{EaD}$ adotou um estilo que perdura até os dias de hoje: apresenta-se através da $\mathrm{EaD}$ online, em que a disseminação do conhecimento é difundido e mediado através do uso da rede mundial de comunicação, a internet. Essa fase 
também é marcada pelo uso do CD-ROM, programas de computadores, materiais didáticos impressos e digitais, entre outros recursos como os $\mathrm{OAs}^{23}$, os $\mathrm{REAs}^{24}$ e as redes sociais. É exatamente nessa última fase que se discutirá sobre o assunto desse capítulo: o Material Didático de Matemática.

$\mathrm{Na}$ EaD o MD tem um tratamento diferenciado, pois o conteúdo trabalhado ganha forma quando passa por um processo que é conhecido nessa área como design instrucional o qual lida com etapas de produção para conferir a qualidade necessária para que um professortutor possa ensinar se utilizando desse recurso didático, isso será apresentado a seguir.

\subsubsection{Concepção de design instrucional}

Para se definir o conceito de design instrucional, deve-se primeiramente compreender os termos: design e instrucional. A fim de que isso ocorra, foi feita uma seleção de pesquisas acadêmicas da área que fazem uma discussão sobre essas terminologias. De acordo com Filatro (2003; 2008), por exemplo, o termo design significa, no plano educacional, um processo ou atividade de um produto com objetivo de torná-lo visível e de refletir quais são as suas formas (sensoriais e cognitivas) e sua função.

Já o termo instrucional, ainda segundo a autora, só pode ser entendido a partir do termo instrução ${ }^{25}$ que diz respeito a uma atividade de ensino que é utilizada na comunicação com o intuito de facilitar a compreensão do conteúdo para a construção do conhecimento.

Sendo assim, ainda seguindo a perspectiva de Filatro (2008), as três principais áreas do conhecimento que dão base à concepção do design instrucional são:

- Ciências Humanas: com atuação em diversas áreas da Psicologia: Comportamental, Cognitiva, Desenvolvimento Humano e Social;

\footnotetext{
${ }^{23}$ OAs - Objetos de Aprendizagem.

${ }^{24}$ REAs - Recursos Educacionais Abertos.

${ }^{25}$ Observa-se que, o significado de instrução utilizado neste estudo vai além da divulgação de informação e execução de tarefas. Diante dessa perspectiva, o termo 'instrução' é entendido, também, como uma forma de orientação do discente, fornecendo-lhe feedback à prática das atividades realizadas com o objetivo de facilitar a aprendizagem desse aluno (FILATRO, 2008).
} 
- Ciências da Informação: com principais áreas de atuação nas Comunicações,

Mídias Audiovisuais, Gestão da informação e na Ciência da Computação;

- Ciências da Administração: com ênfase nas subáreas de Engenharia de Produção, Abordagem Sistêmica e Gestão de Projetos.

A confluência dessas áreas norteia o significado de design instrucional que é definido por Filatro como sendo

\begin{abstract}
(...) a ação intencional e sistemática de ensino que envolve o planejamento, o desenvolvimento e a aplicação de métodos, técnicas, atividades, materiais, eventos e produtos educacionais em situações didáticas específicas, a fim de promover, a partir dos princípios de aprendizagem e instrução conhecidos, a aprendizagem humana (FILATRO, 2003, p. 65, 2008, p.3).
\end{abstract}

Em outras palavras, o design instrucional trabalha com um conjunto de atividades com o objetivo de reconhecer uma necessidade de ensino e aprendizagem, para que se possa fazer uma análise; um design, uma implementação e uma avaliação para solucionar essa necessidade educacional que foi emersa de uma situação e que possa se utilizar dos conhecimentos das três áreas apresentadas anteriormente.

No entanto, cabe aqui ressaltar que o ensino e aprendizagem na $\mathrm{EaD}$, na atualidade, se baseiam nas tecnologias de informação e comunicação online e em recursos educacionais concretos, os quais exigem do design instrucional soluções educacionais para problemas dessa área.

Em geral, as soluções educacionais para o uso do design instrucional podem ocorrer em diferentes níveis: nível macro, quando as experiências de aprendizagem estão ligadas a uma instituição, departamento ou programa; meso, quando o design instrucional é concebido na estruturação de programas, cursos, ou disciplinas; ou micro, em que ocorre nas unidades de estudo, como produção de MD (FILATRO, 2008). Neste estudo, o objeto de estudo de pesquisa situa-se no nível micro, com a realização de um modelo de design instrucional na produção de MD. É o que se discutirá no próximo item.

\title{
3.1.2 O design instrucional contextualizado e os principais atores na produção de material
} didático 
O modelo de design instrucional seguido na confecção de um MD para EaD segue padrões que devem ser analisados para se saber em quais situações isso se aplica, uma vez que o design instrucional, dependendo da situação de aplicação, pode ter tendência a ser tradicional, situado, flexível ou contextualizado (FILATRO, 2003).

Todavia, para essa pesquisa, só interessa tratar do Design Instrucional Contextualizado (DIC), o qual lida com situações didáticas que realçam a qualidade do contexto no processo de planejamento, desenvolvimento e aplicação dessas situações na aprendizagem do aluno. Evidentemente será no DIC que se realizará o processo de contextualização direcionado ao seu público-alvo.

Essa metodologia ${ }^{26}$ favorece as etapas descritas posteriormente que se efetuam no decorrer da produção do MD, e não especificamente nos momentos situacionais da produção delas (GUEDES, 2011). A seguir, descreve-se cada uma das quatro etapas descritas em Filatro (2008) e que são:

- Etapa da Análise - tanto a análise dos diferentes níveis - orientação, instrução e transferência - como as peculiaridades do público-alvo a que se destina a produção desse conteúdo são levadas em consideração;

- Etapa de Design e Desenvolvimento - deve existir uma percepção didática do que está sendo planejado. Neste etapa, os conteúdos devem ser selecionados para compor o que será abordado na produção. Os seus objetivos devem ser direcionados para selecionar quais metodologias e recursos digitais serão usados a fim de desenvolver competências nos alunos daquilo que o professor deseja ensinar;

- Etapa de Implementação - a função principal dessa etapa é ordenar o conteúdo produzido que foi planejado. Enfatiza-se que o compromisso das pessoas envolvidas é importante para o processo de produção desse conteúdo e se espera que os profissionais engajados tenham consciência de seu papel na equipe;

\footnotetext{
${ }^{26}$ O DIC é visto como um tipo de metodologia de produção de recursos didáticos educacionais para muitos autores como Guedes (2011) e Braga (2008), assim como pela própria Filatro (2003; 2008).
} 
- Etapa de Avaliação - nessa última etapa, a avaliação deve ocorrer durante todo o processo de produção do conteúdo, pois as (re)orientações, adaptações, (re)construção devem ser sucessivas no decorrer de toda essa produção.

Para que essa metodologia do DIC aconteça, os profissionais envolvidos na produção do MD ganham importância na execução no processo de produção. Sabe-se que todos os profissionais que lidam com essa temática devem compreender claramente essa metodologia, porém o Designer Instrucional deve compreendê-la mais do que todos os outros.

Em EaD existem múltiplas equipes que conversam entre si, integrando-se em um todo que confere um trabalho de coletividade que é uma característica desse tipo de modalidade de ensino. Segundo Moreira (2012), as equipes os quais são mais encontradas em $\mathrm{EaD}$ são a gestora, a pedagógica, a suporte técnico, a diagramação, de administração da plataforma de aprendizagem e a de produção de MD.

É exatamente na equipe de produção de MD que se encontram diversas atuações de profissionais que estão envolvidos e trabalham em prol da realização de uma concepção pedagógica. Alguns desses atores planejam, desenvolvem, implementam e avaliam o MD, utilizando-se do processo de mediação com o objetivo de construir um MD de qualidade para o aluno.

Diante desse pressuposto, apresentar-se-ão as principais figuras que compõem a equipe de produção de MD. O primeiro é o professor-conteudista ${ }^{27}$, o qual se trata do profissional que desenvolve ou produz o conteúdo que é destinado aos cursos online. Esse profissional precisa ser um especialista ${ }^{28}$ do conteúdo pelo qual é responsável para produzir. Por esse motivo, acredita-se que, por meio de seus conhecimentos adquiridos ao longo de sua formação acadêmica universitária, ele pode desenvolver um MD que seja inteligível a seu público-alvo. No entanto, é necessário saber que o papel que o professor-conteudista desempenha na produção de um MD vai além de produzir conteúdo o qual proporcionará a transmissão de conhecimento.

Parafraseando Belisário (2003), a função do professor-conteudista no processo de confecção do MD está envolvida diretamente sobre a sua atuação na construção do conteúdo

\footnotetext{
${ }^{27}$ Em algumas instituições de ensino o professor conteudista é chamado de professor autor.

${ }^{28} \mathrm{~A}$ produção de MD não fica condicionada a somente uma pessoa, muitas vezes um grupo de especialistas de uma mesma área trabalham com o objetivo de produzir um só MD para certa disciplina de algum curso a distância.
} 
como um norteador do processo de ensino e aprendizagem, com o intuito de fazer com o leitor construa o conhecimento através da busca de soluções para problemas enfrentados no decorrer da aquisição do saber transmitido por esse recurso.

Ainda sob o ponto de vista desse autor, o processo de produção de conteúdo pelo professor-conteudista implica em uma interação ${ }^{29}$ com o seu futuro usuário, por meio de abordagens intuitivas, possibilitando, também, que o leitor (aluno) participe da construção do conhecimento aprendido. O professor-conteudista tem a missão de, além de desenvolver, selecionar os conteúdos que estejam de acordo com a proposta curricular do curso a que se destina o MD.

Esse conteúdo que foi produzido pelo professor-conteudista passará para outro profissional que faz um tratamento de transição pedagógica dessa produção, tentando aproximar, modificar, analisar o conteúdo produzido em um MD adequado ao ensino a distância. Esse outro profissional trata-se do Designer Instrucional (DI), o qual assume uma função primordial de acompanhamento da produção desse recurso educacional.

$\mathrm{O} \mathrm{DI}^{30}$ é o profissional que acompanha o planejamento e produção do conteúdo produzido pelo professor conteudista e que segundo Joye et al (2013), amparado em Filatro (2008), assume a função básica de ser o responsável pelo planejamento, preparação, projeção, produção, e publicação de textos, imagens, gráficos, sons, movimentos, simulações, e atividades avaliativas sustentados em suportes virtuais.

Ainda de acordo com Joye, o MD não é suficiente para a execução de um curso a distância. Segundo as autoras esse recurso didático, por si só, não será suficiente pela execução de um curso a distância, ele precisa estar organizado em uma estrutura que ofereça ao estudante uma aprendizagem mais "fácil" e atraente, já que ele estará estudando remotamente. Percebe-se, nesse aspecto, que o MD precisa estar além da experiência acadêmica do professor-conteudista, do olhar atento e experiente do DI, para que assim o conteúdo possa ser transformado em um material inteligível e acessível para um aluno, um estudante remoto, que se apropriará futuramente esse MD.

\footnotetext{
${ }^{29}$ Segundo Franco (2007), entende-se por interação como um “processo pelo quais interlocutores 'interagem' e decorre daí os efeitos de sentidos" (p. 187).

${ }^{30}$ Outra designação que o Designer Instrucional leva, segundo a Classificação Brasileira de Ocupação do Ministério do Trabalho, é de Designer Educacional (JOYE et al, 2013).
} 
Depois de apresentar as duas principais figuras que acompanham a produção para cursos online, conceitua-se e classifica-se os tipos de materiais didáticos que existem na EaD.

O MD no ensino a distância é considerado, atualmente, como um dos principais recursos educacionais no apoio tanto para o ensino como para a aprendizagem. Sendo esse recurso didático tão importante, deve-se encontrar nele os princípios metodológicos, epistemológicos e políticos no Projeto Político Pedagógico (PPP) do curso para o qual o MD é produzido (BRASIL, 2007).

Em conformidade com o PPP do curso, o MD deve atender ao desenvolvimento de competências e habilidades compatíveis com a realidade socioeconômica de seu público alvo (idem). Diante desse fato, o professor-conteudista tem um grande desafio ao desenvolver esse tipo de recurso educacional, pois não é somente com as experiências adquiridas nos cursos presenciais que ele desenvolverá um MD que atenda a todos os anseios, tanto de ensino como de aprendizagem de um público-alvo que ensina e estuda a distância, respectivamente.

Para se entender melhor a importância de um MD na EaD e para saber a importância do professor-conteudista na produção desse elemento, deve-se conceituar esse recurso didático. De acordo com Braga (2008), um MD pode ser considerado como sendo "todo e qualquer pedaço de conteúdo" sob diversos tipos de formatos: foto, texto, slide, simulação, aula, vídeo, entre outros, que é utilizado para fins educacionais de formação ${ }^{31}$.

Seguindo a mesma linha de raciocínio, Guedes (2008) afirma que o MD pode ser considerado como todo tipo de dado e informação que, se transformado em um documento acessível, é usado como um recurso educacional para o desenvolvimento cognitivo intelectual.

A partir dessas definições, vê-se que a equipe de produção de MD tem um papel fundamental na construção desse recurso. Não somente o professor-conteudista que atua nesse processo de produção, mas também o DI que tem uma função bem definida e amparada nos conhecimentos adquiridos - em ciências humanas, administrativas, e da informação - quando se trata da confecção desse MD.

\footnotetext{
${ }^{31}$ Em Braga (2008), o conceito de "conteúdo didático" assemelha-se ao de "material didático". Muito do que se desenvolveu nessa pesquisa faz referência tanto a um como ao outro como recursos que não há diferenças conceituais. Portanto, nessa pesquisa o conceito de conteúdo didático é considerado um MD.
} 
Há, porém, dois tipos básicos de materiais didáticos que, apesar de terem o mesmo intuito, são de naturezas distintas. Eles são classificados em MD impresso e digital, cada qual com suas peculiaridades. O primeiro com certa tradição histórica, como visto no capítulo 2, no seu uso, enquanto o segundo com fama em sua mobilidade no uso de outros recursos que dinamizam a aprendizagem online. A seguir será desenvolvida uma discussão sobre esses dois recursos didáticos enfatizando suas principais características.

\subsubsection{Material didático impresso}

O Material Didático impresso tem uma sólida tradição de seu uso nas universidades abertas de todo o mundo. A cerca disso, Bédard (2005), em seu artigo sobre o material didático impresso, faz uma retrospectiva desse recurso começando pelos anos 80 (séc. XX) até o início do século XXI. Nesse estudo de Bédard, ele cita o uso do MD impresso nas principais universidades de ensino a distância do mundo:

- 1982: Na universidade Télé-Université, localizada no Canadá, o estudante que estudava a distância utilizava $90 \%$ do tempo de estudos se utilizando o MD impresso;

- 1985: Segundo Bédard (2005, p. 210), “o material didático impresso é o suporte mais utilizado no mundo". A Télé-Université (Canadá) e a Open University (Inglaterra) foram citadas como referências de uso desse suporte educacional;

- 1990: Os recursos audiovisuais (rádio, televisão e cassetes) eram usados como um aporte 'complementar' ao MD impresso, isso na Universidade Nacional de Educação a Distância (Uned) da Espanha; 
- 1993: A Télé-Université desprendia cerca de $60 \%$ a $70 \%$ de suas despesas para a produção de MD impresso. Nessa mesma época, na Universidade da África do Sul (Unisa), o uso do MD impresso era praticamente uma exclusividade ${ }^{32}$;

- 1995: Na Europa, o MD impresso continuava sendo a mídia mais usada na EaD. No Brasil, a Universidade Federal de Mato Grosso (UFMT) iniciou um programa de Licenciatura Plena em Educação Básica, no qual a utilização do MD impresso foi de grande relevância;

- 1999: Foi constatado em pesquisas realizadas tanto na universidade da África como do Brasil que o MD impresso se constitui a peça-chave da comunicação educativa a distância;

- 2000: No Brasil, o MD impresso é visto pela Secretaria de Educação a Distância com um recurso que "vai atrair, porque as mídias mais sofisticadas, mas complexas de uso, têm custo de produção mais alto e limites de acesso para a clientela" (p. 221);

- 2001: Reafirmação da importância do MD impresso como apoio ao ensino e aprendizagem em universidades conceituadas como a Open University; a TéléUniversité; a Universidade Aberta de Portugal; a Universidade Nacional de EaD da Espanha.

O MD impresso, apesar de sua forma rígida e estática ${ }^{33}$, ainda oferece possibilidade de apoio àqueles que não dispõem facilmente de um computador conectado a internet. Como se observou, esse recurso tem presença nos cursos na modalidade a distância, e que ainda se manterá por mais tempo como umas das mídias mais utilizadas na comunicação didática e propagação do conhecimento, o que se alinha ao raciocínio de Berdád (2005) a respeito disso.

Segundo Bédard, a qualidade de um curso de EaD deve ser aliada ou relacionada à qualidade de um MD impresso. Por isso mesmo, a produção dessa mídia deve receber especial atenção, para não ocorrer em gastos desnecessários na sua editoração, a fim de evitar

\footnotetext{
${ }^{32}$ Segundo Bédard (2005), a EaD na sua evolução histórica se propagava de maneira diferente para os diversos países do mundo. Por isso que, na África se compreende que o uso do MD era uma exclusividade.

${ }^{33} \mathrm{O} \mathrm{MD}$ impresso é caracterizado por conservar um padrão característico sem movimento, uma vez que essa mídia é veiculada através de folhas impressas ou por meio eletrônico, geralmente em formato PDF.
} 
erros conceituais repassados nesses materiais para os estudantes que consomem esse recurso nos seus estudos diários. No entanto, além do MD impresso, existe outro tipo de material consolidado nos cursos na modalidade a distância online. Esse recurso é o MD digital que tem como funções facilitar e dinamizar a aprendizagem do aluno.

\subsubsection{Material didático digital}

$\mathrm{O}$ MD digital tem histórico recente que remota à propagação da internet $\mathrm{e}$ web. Pelo fato de ser um tipo de material que se consolidou e evoluiu somente nas últimas duas décadas, ainda há muito a ser explorado nesse tipo de recurso educacional. Ele oferece múltiplas possibilidades para facilitar - devido ao seu dinamismo, atratividade, interatividade e convergência de mídias e recursos - o aprendizado do aluno. Cabe ressaltar, entretanto, que o profissional de design instrucional deve ter conhecimento sobre os recursos digitais que se deve utilizar para tornar o MD mais dinâmico e interativo, visando facilitar o aprendizado do aluno.

Segundo Joye et al (2013), com o fenômeno da web 2.0, há inúmeros recursos digitais para o uso do MD digital que são gratuitos ou pagos, abertos ou não, e que a cada dia estão crescendo e surgindo com novidades para os usuários. As autoras destacam que, entre esses recursos digitais que estão disponíveis para o acesso aos usuários, existem aqueles que se utilizam de tecnologias computacionais, tais como o Java e Flash ${ }^{34}$, para dinamizar, atrair, e servir de apoio a aprendizagem do aluno que estuda a distância.

Embora haja uma gama recursos digitais na web, apresentam-se alguns dos que são usados com frequência nos materiais didáticos digitais de Matemática do curso de Licenciatura em Matemática semipresencial do $\operatorname{IFCE}^{35}$ atualmente. Esses recursos digitais são o Box Icone, os Slider e Slidershow, o Lightbox, o Pop-up Janela.

\footnotetext{
${ }^{34}$ Luft; Scheer e Verzenhassi (2005) definem que Java é uma linguagem de programação que lida com criação de aplicativos voltados à internet, já que é orientada a objeto. Já o Flash foi um programa de computador "desenvolvido pela Macromedia para criação de páginas e/ou componentes gráficos e interativos para Web, como imagens, botões, menus e banners".

${ }^{35}$ IFCE - Instituto Federal de Educação, Ciência e Tecnologia do Ceará.
} 
A definição e exemplo de cada recurso digital utilizado nos MDs desse curso são apresentados na sequência.

\subsubsection{O box icone}

A ferramenta digital Box ícone ${ }^{36}$ tem o papel de 'guardar' um conteúdo específico e diretamente relacionado a um ponto específico do conteúdo no MD. Para um conteúdo de Matemática, ele serve para complementar certo assunto que necessariamente não precise estar no corpo do texto.

Figura 3 - Tela do recurso digital 'Box Ícone' em um MD digital produzido pela $\mathrm{UAB}$ do IFCE.

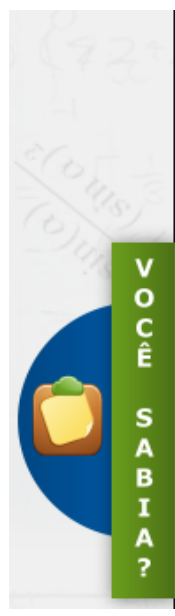

Definição 2: dizemos que uma função $y=f(x)$ é dada implicitamente por tal equação se, para todo $x \in \operatorname{Dom}(f(x))$, o ponto $(x, f(x))$ for solução da equação.

Fonte: Alves (2011).

Na Figura 3, observa-se que, no MD de Cálculo I produzido na UAB do IFCE, o autor explica ao leitor - através do Box ícone "Você Sabia?"37 - que o conceito relativo ao "Derivada de uma função" é conceito formal dado pela Matemática e que será mais bem compreendido com dedicação ao estudo desse conceito.

\footnotetext{
${ }^{36}$ Esse é único recurso comum tanto ao MD digital como ao impresso. A diferença do uso desse recurso de um para o outro é que, no digital, o recurso tem movimento, já no impresso é estático e está ligado por uma linha pontilhada ao termo do conteúdo que precise usar essa ferramenta.

${ }^{37}$ Além do ícone "Você Sabia?", têm-se outros ícones com outras designações, tais como "Atenção!", "Saiba Mais!", que são utilizados com frequência em materiais didáticos digitais da DEaD/UAB do IFCE.
} 


\subsubsection{O slider ou slideshow}

Outra ferramenta digital que é bastante utilizada nesse tipo de MD é um recurso chamado Slider ou Slideshow. A diferença básica entre um e outro é que o Slider é usado para sequenciar subitens que, na maioria das vezes, trazem definições. Já o Slideshow costuma ser mais usado para sequenciar imagens. Na Figura 4, na disciplina de Laboratório de Ensino de Matemática, pode-se verificar o uso do recurso Slideshow.

Figura 4 - Tela do recurso digital 'Slidershow' em um MD digital produzido pela UAB do IFCE.

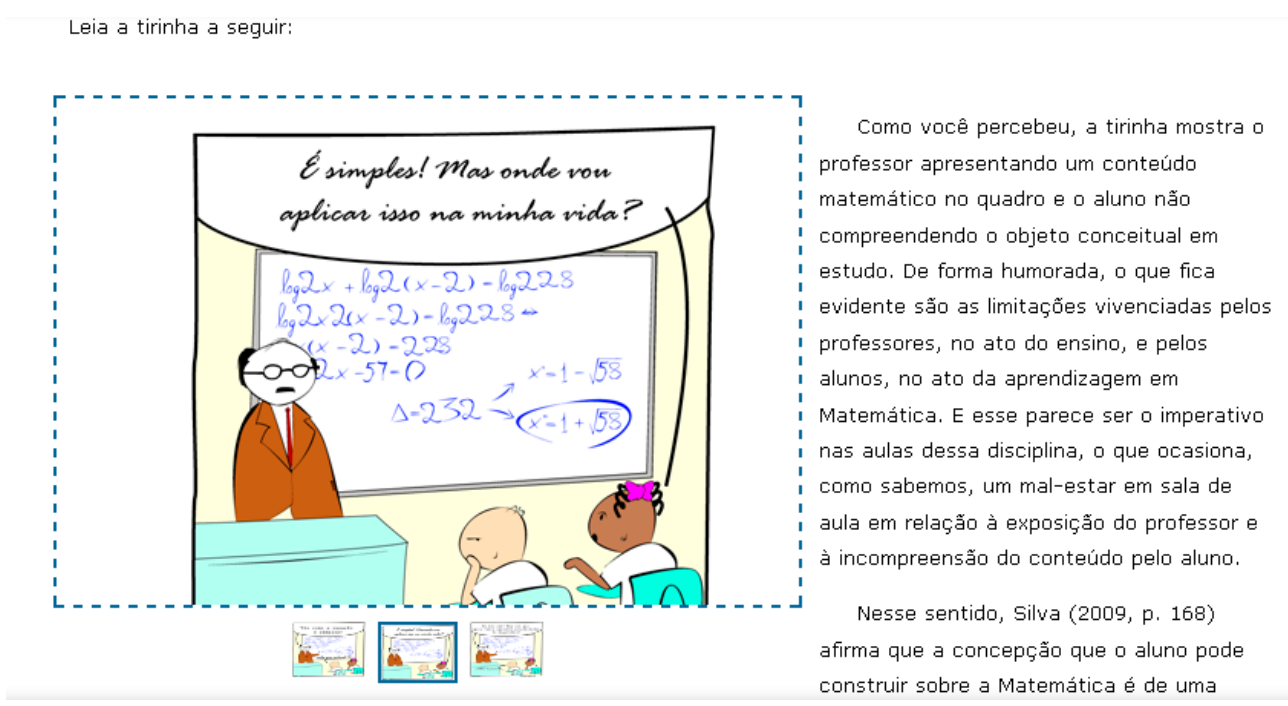

Fonte: Joye et al (2013).

\subsubsection{O lightbox}

O Lightbox é o mais utilizado entre os recursos. Ele tem a função de 'esconder ou mostrar' imagens que, "necessariamente não precisem estar ocupando lugar considerável no corpo do texto" (JOYE, 2013). Como exemplo disso, na Figura 5, mostra-se o uso desse recurso ainda na disciplina de "Cálculo I" do curso de Licenciatura em Matemática.

Figura 5 - Tela do recurso digital 'Lightbox' em um MD digital produzido pela UAB do IFCE. 


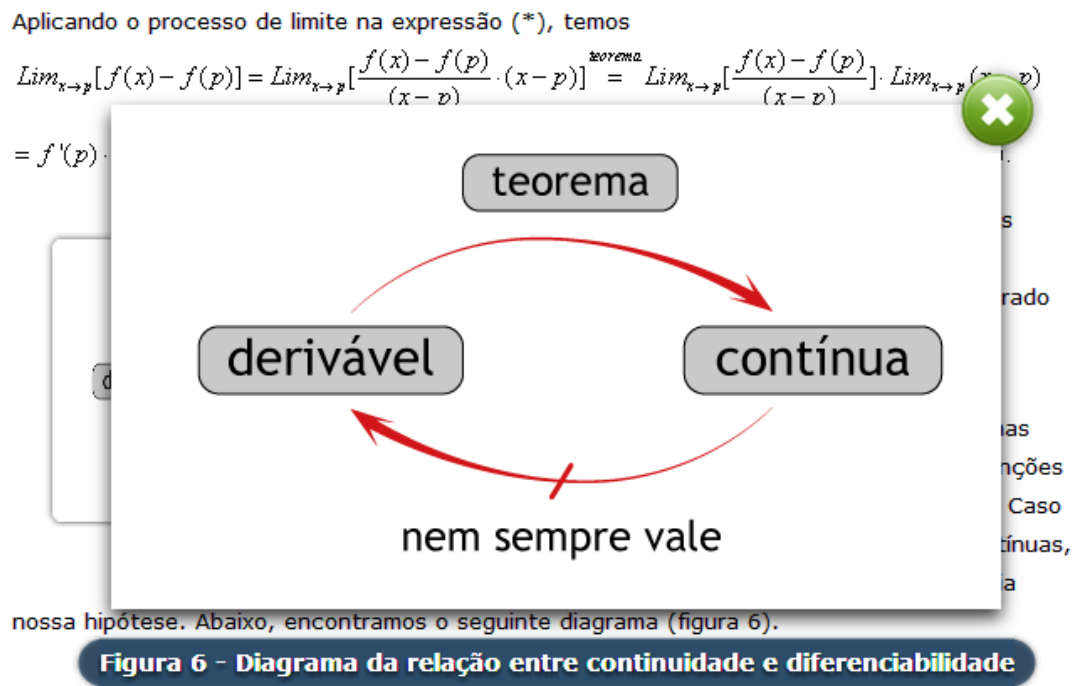

Fonte: Alves (2011).

\subsubsection{O pop-up janela}

Por último, um recurso que costuma ser usado para algum texto que seja considerado muito longo para ser apresentado no corpo do conteúdo do material é o Pop-up Janela. Além de textos, ele serve também para imagens, tabelas, ou vídeos. Esse recurso pode ser verificado na Figura 6, na disciplina de "Estatística e Probabilidade" produzida pela UAB do IFCE.

Figura 6 - Tela do recurso digital 'Pop-up Janela' em um MD digital produzido pela UAB do IFCE.

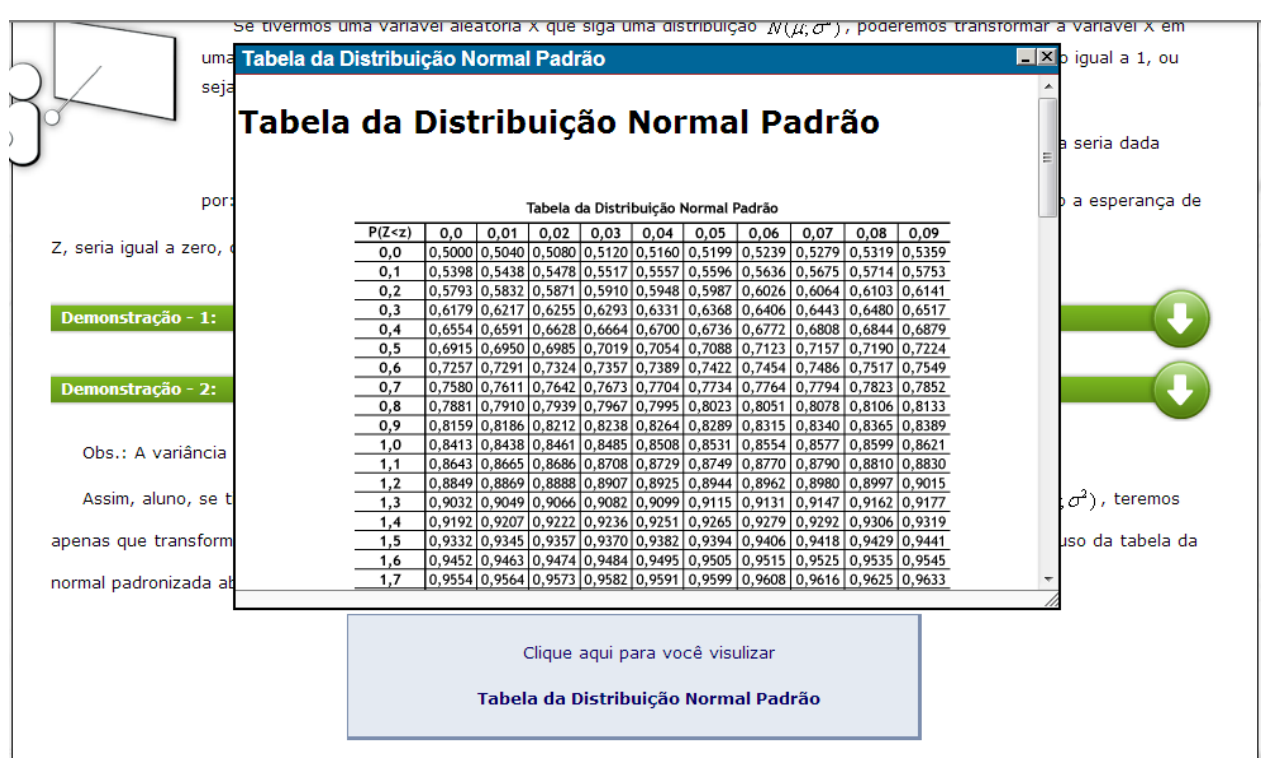


Fonte: Joye et al (2013).

É claro que, além desses recursos digitais, existem outros que são usados e explorados em um material didático digital. Isso acontece, dentre outros aspectos, porque o MD digital ainda tem uma história recente. Com certeza, haverá o desenvolvimento e florescimento de outros recursos digitais com o objetivo de dinamizar e tornar inteligível o conteúdo explorado.

Cabe nessa perspectiva a atuação do DI com a devida competência para adequar, estudar, analisar e planejar o uso e inserção dessas ferramentas digitais nos materiais didáticos digitais, assim como também de se atualizar frente aos novos recursos digitais que surgirão no decorrer do desenvolvimento tecnológico.

No entanto, o DI necessita ter atenção na distribuição dessas ferramentas no MD, assim como também precisa estar atento aos detalhes que são de cunho estrutural e pedagógico para confecção desse recurso didático, seja ele impresso ou digital para ajudar e guiar o professor-conteudista na produção desse MD. Isso será discutido a seguir.

\subsubsection{Características da estrutura pedagógica de um material didático para EaD}

Um material didático segue padrões que precisam estar de acordo com o públicoalvo ao qual se destina. Portanto, ao elaborar um MD, o professor-conteudista deve considerar quais são as competências a serem desenvolvidas no aluno e isso deve estar claro no material didático. Para que isso ocorra, Franco (2007) afirma que a preparação de um MD deve se alinhar a uma estrutura pedagógica que conduza o aluno a uma aprendizagem significativa. Nesse sentido, devem-se conceber estratégias de produção do MD focadas na orientação e facilitação da aprendizagem.

Para ajudar o professor-conteudista nesse trabalho, alguns critérios de elaboração de um MD são apontados por Brasil (2007) e são mencionados, com outras perspectivas, em trabalhos como de Franco (2007), Neder (2005) e Churches (2009). Esses critérios que 
norteiam a elaboração de um $\mathrm{MD}^{38}$ foram separados em três partes: Sistematização e Organização do conteúdo; Linguagem; e Aprendizagem centrada no discente, eles são apresentados nos próximos subitens.

\subsubsection{Sistematização e organização do conteúdo}

Brasil (2007) e Franco (2007) apontam que, para cada unidade, deve-se ter clara a apresentação do conteúdo e dos tópicos, assim como se devem propor atividades ao aluno com o objetivo de praticar os conceitos que estão sendo apresentados. Outro ponto importante é que os objetivos devem estar de acordo com o desenvolvimento cognitivo do aluno, com a intenção de promover a sua autonomia. Franco (2007) menciona que, se o aluno souber para onde está indo, será capaz de avaliar se, realmente, aprendeu com o conteúdo estudado.

$\mathrm{Na}$ organização de um tópico, deve haver uma introdução para preparar cognitivamente o aluno e também um fechamento do tópico, posteriormente de uma aula, para o aluno verificar se conseguiu atingir os objetivos explicitados naquele tópico.

Outro fator que é tão importante quanto a 'Sistematização e organização do conteúdo' é a linguagem utilizada na produção de um MD para ensino a distância. No próximo subitem discute-se sobre esse assunto na perspectiva de alguns autores.

\subsubsection{Linguagem}

A linguagem utilizada em um texto para EaD deve ser autoexplicativa e orientar o aluno na compreensão do conteúdo. Dentre os vários aspectos que permeiam essa linguagem utilizada em texto para a EaD, duas são de relevância para se explorar.

A primeira é a comunicação bidirecional, na qual há presença de uma linguagem dialogada. Segundo Franco (2007), ao se produzir um texto para EaD, deve-se considerar que

\footnotetext{
${ }^{38}$ Cabe aqui ressaltar que o MD, antes de qualquer procedimento, tem uma organização estrutural do conteúdo que segue uma sequência de construção para cada estrutura temática: aula, tópicos e subtópicos. Aqui, deve-se observar qual a carga horária da disciplina para a construção do MD, para saber em quantas aulas podem ser divididas.
} 
é importante o professor-conteudista explicitar aspectos que promovam uma situação de ensino e aprendizagem "face a face", já que o aluno deverá estudar, em muitas ocasiões, sozinho.

A segunda é a comunicação interativa. Nela os sujeitos envolvidos no processo de ensino e aprendizagem são (co)participantes ativos da construção do conhecimento. Entende-se que a mensagem transmitida no conteúdo é construída tanto por quem ensina como por quem aprende.

Nessa mesma perspectiva, Neder (2005) discute que, na comunicação interativa, há uma "rede" com infinitas possibilidades de construção do saber entre esses sujeitos envolvidos, na qual a mensagem é algo modificável por ambas as partes, pois o conteúdo é não fechado e sim passível de interações entre esses sujeitos.

A linguagem vai estar em consonância com essas duas características, as comunicações: bidirecional e interativa, os quais devem nortear o professor-conteudista na produção de um MD para $\mathrm{EaD}$, para que assim ele possa ter uma proximidade com o seu leitor, o qual consumirá esse MD e que no caso é o aluno.

Para além dessas características, deve-se enfatizar que toda a construção desse MD é pautada na aprendizagem do aluno. Isso é um assunto que vai ser discutido a seguir, quando se enfatiza que a aprendizagem deve ser centrada no discente.

\subsubsection{Aprendizagem centrada no discente}

Quando a construção de um MD é realizada, primeiramente, se pensa na aprendizagem que, como se sabe, deve ser centrada no aluno. Essa aprendizagem se baseia nas habilidades que devem ser desenvolvidas com a explicitação dos objetivos a priori.

A elaboração dos objetivos para um MD deve ser um dos primeiros passos a se realizar no planejamento do material didático e seu uso. Esses objetivos são explicitados no início de cada aula ou tópico e devem ser colocados em ação pelo aluno. Para apoiar essa construção, buscam-se subsídios, geralmente, na 'Taxonomia de Bloom' que, de acordo com 
Churches (2009), é uma teoria que estuda o processo de aprendizagem através de objetivos apoiados em três áreas do domínio psicológico: o afetivo, o psicomotor e o cognitivo.

Cada uma desses domínios desenvolvem competências ligadas à aprendizagem. Sendo assim, o domínio afetivo, ainda de acordo com Churches (2009), revela desenvolver capacidades, tais como as "atitudes e sentimentos" (CHURCHES, 2009, p.4) no discente. Já o domínio psicomotor está diretamente ligado ao desenvolvimento de "habilidades manipulativas, manuais ou físicas" no aluno. Por último, o domínio cognitivo lida com o "processamento de informações, conhecimentos e habilidades mentais" (idem) do indivíduo, que deve estar mais evidentes nos MDs.

Figura 7 - Comparação da Taxonomia de Bloom antes e depois de ser revisada.

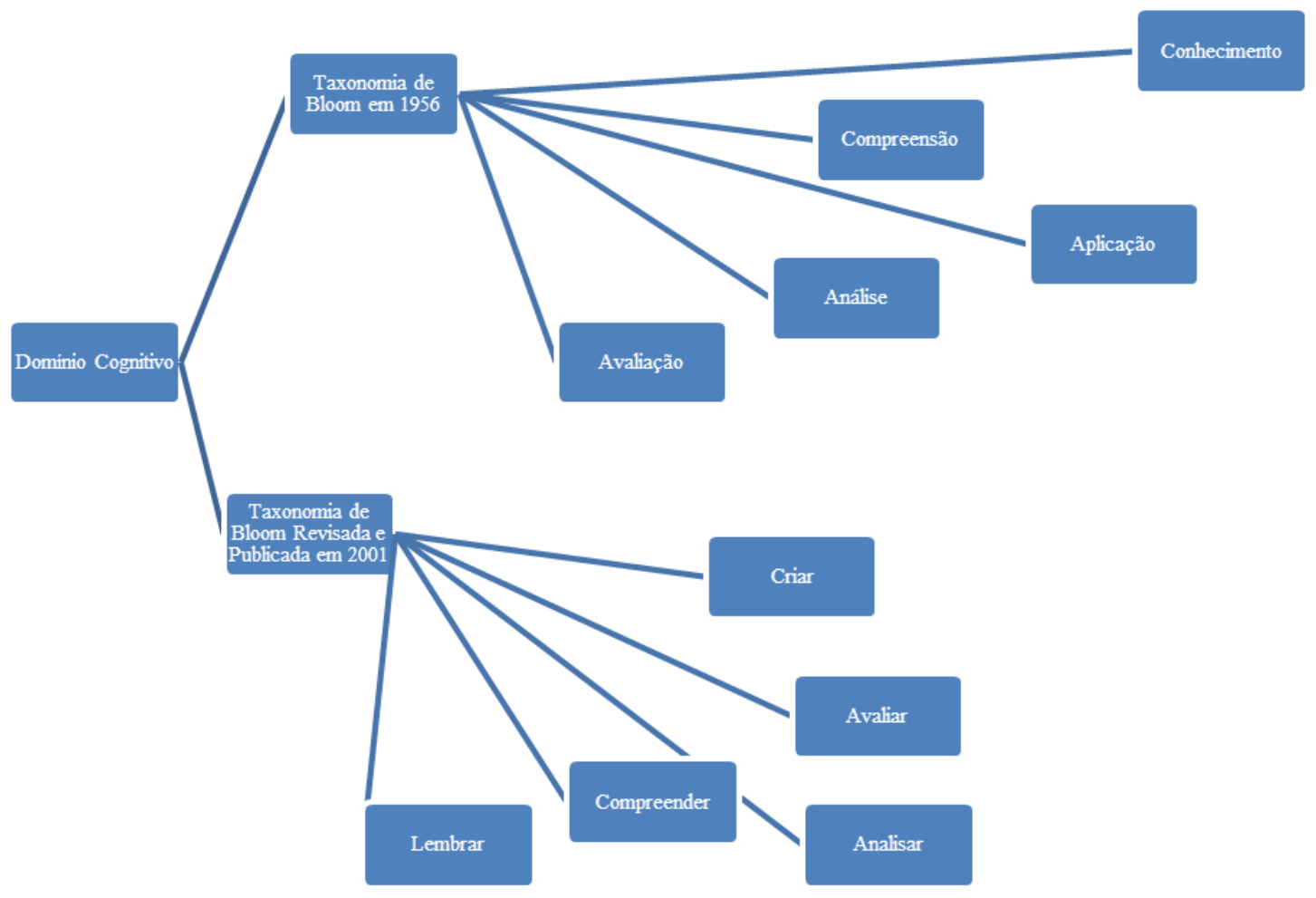

Fonte: Churches (2009).

No entanto, as competências ligadas ao domínio cognitivo foram revisadas décadas depois da teoria de Bloom (originalmente de 1956). Essa revisão foi feita no início da década de noventa, do século passado, e publicada em 2001. Nela a teoria de Bloom foi revisada e realizada um rearranjo desse domínio. Observa-se na Figura 7 que algumas competências mudaram na revisão publicada em 2001. As habilidades que deveriam ser 
desenvolvidas se encontram como verbos de ação para exprimir a atividade que o aluno desenvolveria no decorrer do processo de aprendizagem.

Essas competências, porém, ainda não davam conta da demanda exigida nos tempos atuais, em que o conhecimento é propagado e disseminado mais rapidamente através das tecnologias digitais. Então, a teoria foi, novamente, revisada e atualizada para essa realidade. Assim se teria uma 'Taxonomia de Bloom Digital' (CHURCHES, 2009).

Churches discute que, nessa nova versão da teoria de Bloom, as competências que se devem desenvolver giram em torno das categorias apresentadas a seguir (Figura 8). Nela todas são categorias que devem desenvolver outras habilidades nos alunos.

Figura 8 - Competências a se desenvolver no aluno na Taxonomia de Bloom Digital.

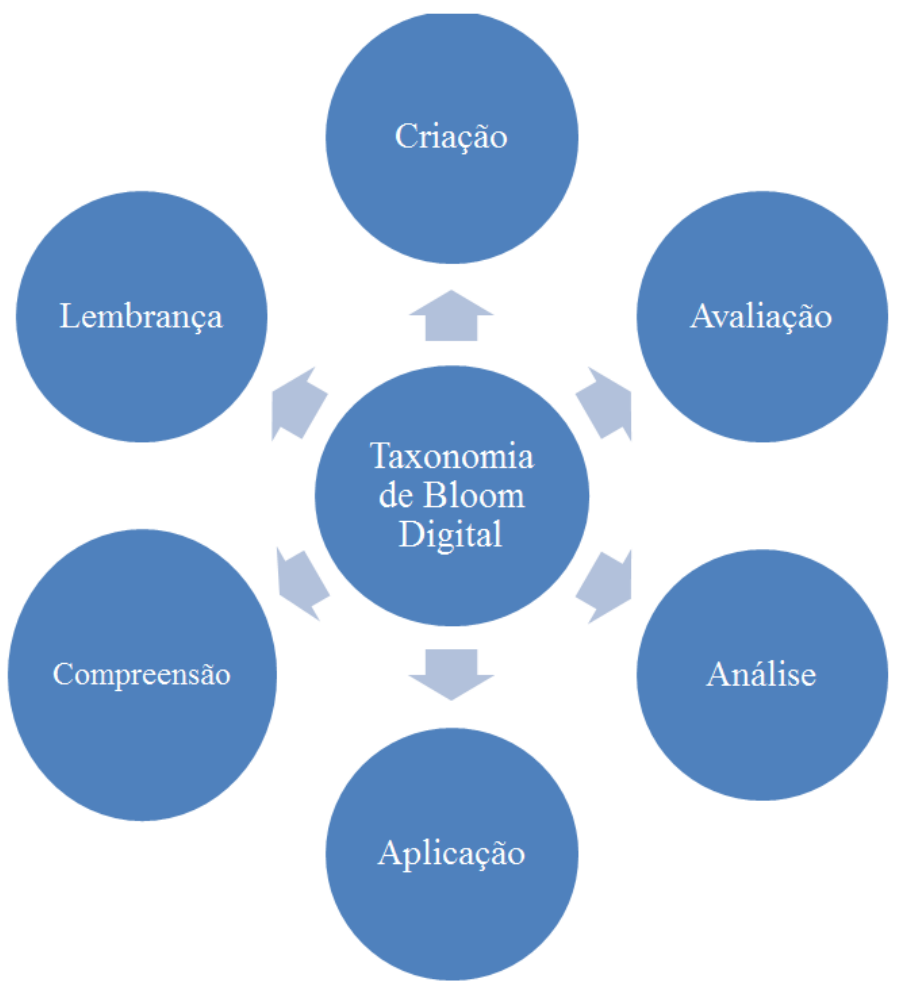

Fonte: Churches (2009).

Esses domínios são também apontados em Brasil (2007), quando deixa claro que o MD deve atender tanto às orientações quanto à sua elaboração. Trata também de que cada aula e tópico devem apresentar as competências cognitivas, afetivas e psicomotoras para que o aluno possa, ao final da aprendizagem, fazer uma autoavalição do que aprendeu. 
Por fim, depois de apresentar todas essas características inerentes à elaboração de um MD, se discutirá, no próximo item, sobre a concepção de um MD para a área de Matemática, com ênfase no conceito de transposição didática.

\subsection{O Material Didático de Matemática para EaD}

Diante dos conceitos apresentados sobre a construção de um material didático para o ensino a distância, faz-se uma reflexão sobre um MD para uma área específica do saber: a Matemática. Um MD de Matemática traz todos os elementos característicos desse tipo de recurso didático, inclusive os três elementos-chave do processo de ensino e aprendizagem do triângulo didático: o saber, o professor e o aluno (Figura 9).

Figura 9 - Triângulo Pedagógico do Ensino e Aprendizagem.

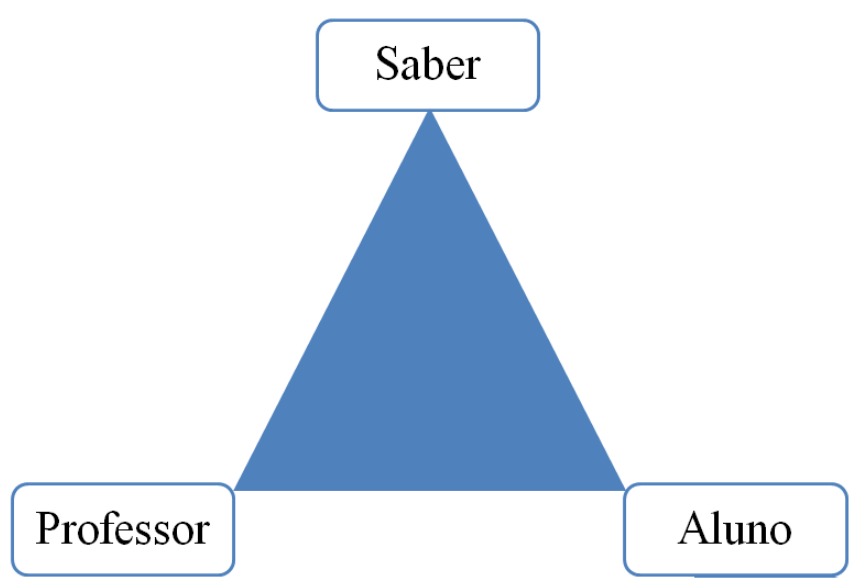

Fonte: Houssay (1988).

Joye (2013), baseada no triângulo pedagógico de Houssay (apud JOYE, 1988), discute as relações que esses três conceitos têm uns com o outros. De acordo a autora, as relações entre esses conceitos se dão dois a dois: Professor-Saber; Professor-Aluno; e AlunoSaber. Suas características são explicitadas no Quadro 3:

Quadro 3 - Características das relações entre professor-aluno-saber. 


\begin{tabular}{|l|l|l|}
\hline$\bullet$ Processo ensinar & $\bullet$ Processo formar & $\bullet$ Processo aprender \\
$\bullet$ O professor se preocupa & $\bullet$ Há uma relação pedagógica & $\bullet$ Métodos didáticos \\
com o conteúdo (saber) & entre os sujeitos & apoiados nas teorias da \\
que deve ser ensinado & $\bullet$ O aluno é um sujeito ativo & aprendizagem \\
$\bullet$ Ocorre a ação didática & $\bullet$ O professor é o facilitador da & $\bullet$ Presença das teorias \\
& mediação da aprendizagem & cognitivistas \\
& entre o saber e o aluno & $\bullet$ O aluno é o foco do \\
& & processo \\
\hline
\end{tabular}

Fonte: Joye (2013).

Como se pode observar, na relação professor-saber, há uma preocupação por parte do professor no processo de ensino quando ele pensa na elaboração didática da apresentação dos conteúdos. É nesse momento que ele deve selecionar qual metodologia de ensino se adequa melhor ao seu público-alvo, quais conteúdos (saberes) deve abordar, qual pensamento pedagógico deve priorizar para a construção dos conteúdos, etc. Dito de outra forma: é justamente aqui que acontece o fenômeno da transposição didática que já foi introduzido antes e será apresentado a seguir com mais profundidade.

\subsubsection{O conceito de transposição didática}

Como o professor, hoje em dia, lida com a situação de difundir o conhecimento científico puro sem simplesmente reproduzir ideias científicas das obras e teorias clássicas da Matemática? Uma questão como essa deve ser tratada como um assunto a ser investigado sob a ótica da didática.

A didática é uma linha de pesquisa relevante que vem sendo estudada nas últimas décadas por pesquisadores em Educação Matemática, em especial, na França, onde há trabalhos que foram e estão sendo desenvolvidos em área específica de Didática da Matemática. Um notável pesquisador dessa área é o professor Yves Chevallard ${ }^{39}$ que pesquisa

\footnotetext{
${ }^{39} \mathrm{O}$ pesquisador Yves Chevallard mantém uma página na internet onde se encontram anais de suas pesquisas que foram desenvolvidas desde 1971 no campo da Didática da Matemática. Alguns textos, em sua maioria, encontram-se na língua nativa do pesquisador, em francês, embora haja alguns em inglês. Para acessar esses anais, deve-se recorrer ao site http://yves.chevallard.free.fr/spip/spip/.
} 
o conceito de transposição didática no ensino de Matemática. A transposição didática é uma teoria que tem como foco principal o processo de ensino, no qual as principais figuras centrais são o saber e o professor.

Do ponto de vista de D'Amore (2007), baseado em estudos realizados por Chevallard (1994), essa teoria é um processo que faz com que o conhecimento matemático seja adaptado, transformado ou modificado para torná-lo um conhecimento que possa ser ensinado. Para D’Amore, a transposição didática consiste em fazer com que o professor faça uma construção de suas próprias aulas extraindo das fontes de saberes, que adquiriu durante sua vida acadêmica e apoiando-se nas orientações fornecidas em currículos e programas dos cursos, a fim de adequá-los ao nível de compreensão do aluno.

Para dar mais base ao que foi dito, Joye (2013) explica que a transposição didática tem como preocupações básicas no processo de ensino as seguintes variantes:

Figura 10 - As variantes que estão ligadas a transposição didática no processo de Ensino.

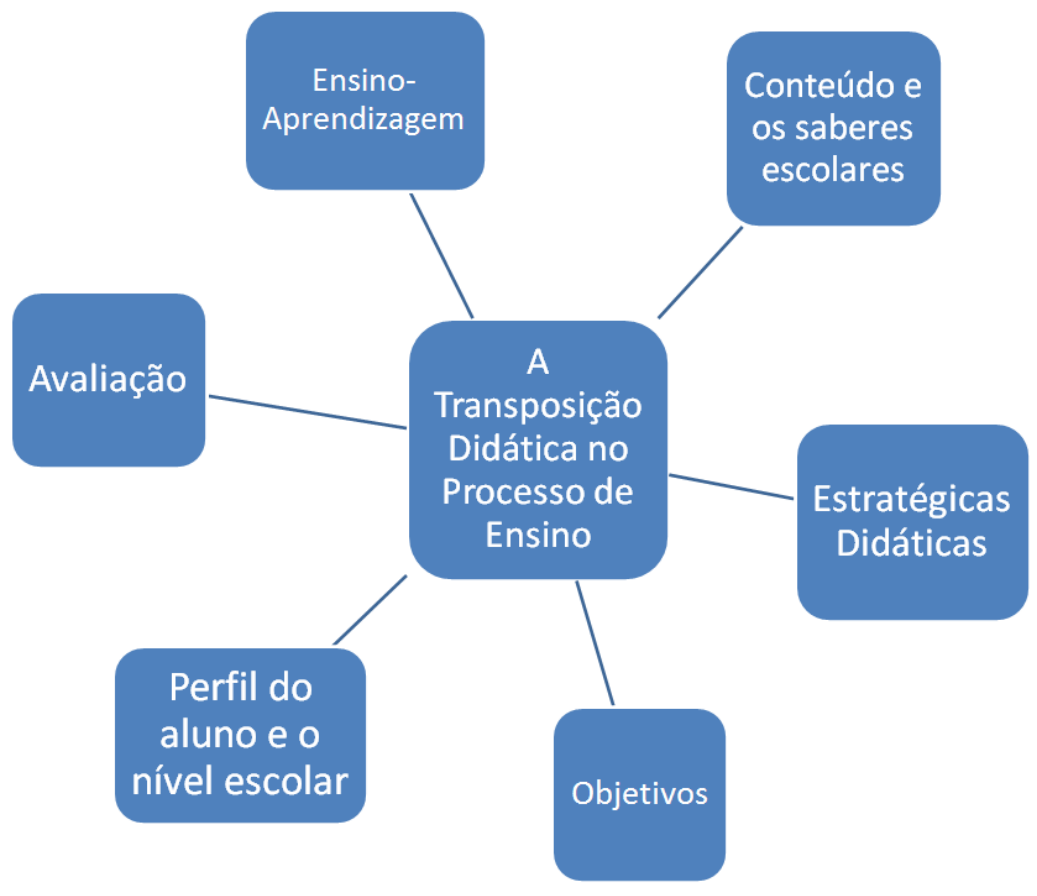

Fonte: Joye (2013).

Na Figura 10, fica evidenciado como a transposição didática acontece no processo de ensino. Desse modo, o professor-conteudista na produção de um MD de Matemática deve estar atento para saber 'o que se deve ensinar?', ou seja, quais conteúdos devem ser pautados 
em cada programa curricular; 'como ensinar?', adequar esses conteúdos a melhores estratégias de ensino; 'para que ensinar?' se pautando em objetivos que desenvolvam competências nos alunos; 'para quem?' se deve ensinar, respeitando as particularidades culturais de quem está aprendendo; e 'como avaliar?' a aprendizagem do aluno, o qual deve perceber que está em um processo, em que ele é avaliado e se autoavalia.

Nas palavras de Chevallar, Bosh e Gascón (2001), há uma tendência sobre a não realização de uma transposição didática dos conteúdos matemáticos, uma vez que "a tendência habitual é considerar que as adaptações escolares de uma obra matemática são imitações mais ou menos fiéis desta e, portanto, os complexos processos de transposição didática não são considerados" (CHEVALLAR; BOSH; GASCÓN, 2001, p. 143).

Em realidade, esse tipo de procedimento é efetuado em muitas ocasiões quando se trata da confecção de um MD de Matemática. A abordagem do conteúdo matemático ainda é, em muitas ocasiões, uma reprodução de compêndios de grandes obras da Matemática, como foi explicitado no capítulo 2 dessa pesquisa. Nele também se observou que o uso de livros didáticos no ensino de Matemática para o ensino superior se realizava através de reprodução e/ou tradução das obras matemáticas que estavam evidenciadas na época. Isso, de certa forma, acabou que 'normalizando' a cultura nas universidades de que um bom livro didático de Matemática tem que ser uma reprodução fiel dos grandes compêndios matemáticos produzidos pelos notáveis matemáticos daquela época.

Pedagogicamente e didaticamente isso não deve acontecer, pois um MD de Matemática deve priorizar e ser centrado na aprendizagem do aluno. Aqui, cabe ressaltar a atuação do DI para que esse tipo de transposição não ocorra. O DI deve orientar o professorconteudista para fazer uma construção de um MD se baseando nos elementos que a transposição didática fornece.

A transposição didática ainda favorece a contextualização dos conteúdos. Isso vai ao encontro do que foi apresentado anteriormente, quando foi falado do Design Instrucional Contextualizado e sua importância na produção de um MD para ensino a distância. D'Amore (2007), porém, discute que, quando a transposição didática acontece, há uma 'descontextualização de um conceito matemático', para que haja, logo depois, uma 'recontextualização dessa noção matemática' que está sendo ensinada. Ou seja, há um processo de construção, desconstrução e reconstrução do saber matemático. 
Nesse processo de construir, descontruir e reconstruir os conceitos matemáticos que estão sendo ensinados, o processo deve ser feito de tal forma que oriente o aluno na apreensão desses conceitos. Logo, nesse ato de transpor o conhecimento de forma didática para o aluno, reflete-se sobre uma metodologia de ensino que o oriente na apropriação do saber matemático de forma que ele seja um sujeito ativo da construção do conhecimento fornecido para ele.

Considerando essas bases, para fechar esse capítulo, discute-se a seguir a função que a transposição didática tem em uma metodologia de ensino de Matemática chamada Sequência FEDATHI e quais são os impactos que essa metodologia causa na produção de um MD pelo professor-conteudista dessa área.

\subsubsection{O papel da transposição didática na Sequência FEDATHI}

A Sequência FEDATHI é uma metodologia de ensino que é composta de quatro etapas que, segundo Borges Neto e Santana (2003), envolvem, também, os três elementos do processo de ensino e aprendizagem: o professor, o aluno e o saber.

Como explicitados em pesquisas de Moreira e Pinheiro (2013), Moreira e Rocha (2011) e Moreira (2009), as quatro etapas da metodologia de ensino, desenvolvida por Borges Neto, consistem no seguinte:

1) Tomada de Posiçãa - a abordagem e apresentação que o professor faz quando introduz um conceito matemático, tem o objetivo principal de criar elementos que sejam necessários à aprendizagem do discente, para que assim o aluno fique imerso no mundo cultural do assunto que está sendo estudado, apoderando-se do papel de pesquisador, restando ao docente a função de intermediador e/ou facilitador desse processo de aprendizagem.

2) Maturação e Debruçamento - aqui o professor estimula o aluno nas discussões sobre o conceito matemático estudado e explorado, com o intuito de propor ao estudante que ele desenvolva argumentações sobre o raciocínio que está em processo de desenvolvimento. Nesse momento, o aluno se debruça sobre o 
problema estudado e trabalha nele com o objetivo de desenvolvê-lo e, talvez, encontrar a resposta procurada. O professor tem uma função, nesse momento, passiva, pois estará ajudando o aluno a enveredar-se por uma solução, ou várias soluções, que talvez possa encontrar a resposta final.

3) Solução - o professor propõe ao aluno que faça uma sistematização da solução e tente debatê-la e discuti-la entre os seus pares, com o intuito de desenvolver a argumentação lógica de raciocínio dele.

4) Prova - Nessa última fase, o professor sistematiza e formaliza de maneira adequada a solução, não se esquecendo de empregar a simbologia matemática necessária para concluir o raciocínio exposto pelo problema inicial. No entanto, o professor não desconsidera a possível solução dada pelo aluno.

Todos os procedimentos pontuados na Sequência FEDATHI, que dão apoio ao ensino por parte do professor, correspondem ao conceito de transposição didática estudado em Chevallard. Como Borges Neto e Santana (2003) deixam claro, a Sequência FEDATHI pode ser considerada uma transposição didática, pois a todo momento ela faz um convite ao aluno para que este tenha uma experiência matemática significativa, em que ele (aluno) é sujeito ativo e construtor do conhecimento apreendido.

O professor-conteudista de Matemática, com a ajuda do DI, tem de conduzir, orientar, convidar o aluno a viver uma experiência matemática significativa e isso ocorre com uma transposição didática bem feita, ou melhor, isso acontecerá quando a Sequência FEDATHI for sendo colocada em ação.

Considerando todas as etapas elencadas anteriormente, o uso e aplicação do material didático de Matemática pelo professor-tutor são importantes para orientá-lo a ensinar o conteúdo matemático. Esse conteúdo deve levá-lo a orientar o aluno no estudo dos conceitos trabalhados, contribuindo para que este aluno tenha essa experiência matemática significativa.

No próximo capítulo, falar-se-á sobre o percurso metodológico da pesquisa. Serão apresentados os eixos norteadores, o contexto da pesquisa e os instrumentos utilizados na pesquisa de campo dessa investigação, visando analisar a visão do professor-tutor sobre a adequabilidade do material didático, no caso da disciplina de Cálculo I do curso de Licenciatura em Matemática semipresencial do IFCE, à luz da Sequência FEDATHI. 


\section{PERCURSO METODOLÓGICO DA PESQUISA}

Esse capítulo trata do caminho metodológico para a construção da pesquisa. Nele, descrever-se-á o contexto da pesquisa, assim como os elementos ligados ao objeto de investigação, que, no caso, é a visão do professor-tutor sobre a adequação do MD de Cálculo I na modalidade semipresencial de ensino superior à luz da Sequência FEDATHI, o qual está ligado à problemática. O capítulo se finalizará com a descrição dos instrumentos de investigação e dos sujeitos estudados.

\subsection{Contexto situacional da pesquisa e os eixos norteadores}

Essa pesquisa teve como lócus a Diretoria de Educação a Distância (DEaD)40 do Instituto Federal de Educação, Ciência e Tecnologia do Ceará (IFCE). Atualmente, há cursos ofertados pelo Educação Profissional e Tecnológica na modalidade a distância (E-Tec), pela Universidade Aberta do Brasil (UAB) e pela Pós-Graduação semipresencial41. Em nível de E-Tec, têm-se os seguintes cursos: Edificações; Informática; Eletrotécnica; Segurança do Trabalho; Meio Ambiente; Redes; Comércio e Agronegócio, com polos localizados nas cidades do estado do Ceará (Aracati, Campos Sales, Crateús, Horizonte, Pacajus, Russas, Tauá e 'Portuário'- Fortaleza).

No ensino superior, pela UAB, têm-se as seguintes graduações: Tecnologia em Hotelaria; Licenciatura em Matemática; e Licenciatura em Educação Profissional, Científica e Tecnológica (EPCT), atualmente distribuídos nos polos de Acaraú, Beberibe, Camocim, FECET Caucaia, Jurema Caucaia, Itapipoca, Jaguaribe, Meruoca, Quixeramobim, Tauá, Orós, Ubajara, Limoeiro do Norte, São Gonçalo do Amarante e Campos Sales, todos do estado no Ceará.

\footnotetext{
${ }^{40} \mathrm{~A} \mathrm{DEaD}$, vinculada à pró-reitoria de Ensino do IFCE, se localiza no campus Fortaleza do IFCE, cujo endereço é Avenida Treze de Maio, nº 2081, Bairro: Benfica. Cep: 60040-531 - Fortaleza, Ceará.

${ }^{41}$ Para mais informações, segue link do AVA onde se encontram os cursos semipresenciais ofertados pela DEaD: http://virtual-novo.ifce.edu.br/
} 
Em nível de pós-graduação, têm-se os cursos de Educação para a Diversidade; Educação para Jovens e Adultos; Educação Ambiental; Produção de Material Didático; Turismo e Hotelaria; e Educação Profissional. Além desses, há os cursos que são ofertados pelo Profuncionário em nível técnico, como Gestão Escolar; Alimentação Escolar; Infraestrutura e Meio Ambiente; e Multimeios Didáticos.

Vale ressaltar que a pesquisa teve como foco somente o curso de Licenciatura em Matemática semipresencial, cuja coordenação pedagógica está localizada no município de Juazeiro do Norte, no campus42 do IFCE (Avenida Plácido Aderaldo Castelo, no 1646, Bairro: Planalto, CEP: 63.040-540). Nessa coordenação, encontram-se as seguintes equipes: a coordenação do controle acadêmico; a coordenação de tutoria da Matemática; e a coordenação de administração financeira.

O curso de Matemática é ofertado para doze municípios do interior do Ceará (Acaraú; Itapipoca; São Gonçalo do Amarante; Meruoca; Camocim; Quixeramobim; Limoeiro do Norte; Campos Sales; Orós; Ubajara; Jaguaribe; e Itapipoca). O campus de Fortaleza assume uma função de apoio ao curso. Ele se incorpora à equipe da $\mathrm{DEaD}$ com as seguintes coordenações: a equipe multidisciplinar de produção de material didático43; a coordenação geral da UAB do IFCE; e a coordenação da DEaD do IFCE.

Delimitando ainda o campo de ação da investigação, os estudos realizados foram dirigidos aos materiais didáticos do curso de Licenciatura em Matemática semipresencial da UAB produzido pela equipe de produção de Material Didático da DEaD do IFCE, em especial a disciplina de Cálculo Diferencial e Integral I, mais comumente conhecido por Cálculo I e seu uso pelos professores tutores.

A escolha dessa disciplina se deu a partir de eixos norteadores que já foram explicitados na introdução e que são novamente expostos aqui. Sabe-se que o material didático é um apoio ao ensino e aprendizagem de quem leciona e estuda a distância. Sendo assim, a atual pesquisa preocupa-se em saber, na visão do professor-tutor que o aplica, se o Material Didático de Cálculo I está adequado às necessidades de ensino a distância com um

\footnotetext{
${ }^{42}$ Para mais informações sobre o campus de Juazeiro do Norte do IFCE, acessar página: http://www.juazeirodonorte.ifce.edu.br/

${ }^{43}$ Essa equipe era composta com a equipe de Designers Instrucionais; de professores conteudista; revisores textuais; profissionais de diagramação web e impresso; profissionais de desenho gráfico, iconografia.
} 
uma metodologia baseada na Sequência FEDATHI, tanto impresso como web, do curso de Licenciatura em Matemática semipresencial.

Essa foi a grande indagação que se fez nessa pesquisa e que se tentou responder. Para isso ocorrer, seguiu-se um percurso de pesquisa no qual foram investigados temas como Ensino de Cálculo; Didática da Matemática; Transposição Didática; Sequência FEDATHI; Material Didático de Matemática, entre outros assuntos aqui discutidos.

Para melhor compreender sobre em que aspectos o material didático de Cálculo I foi analisado, será descrito a seguir o material didático de Cálculo I produzido pela $\mathrm{UAB} / \mathrm{DEaD}$ do IFCE.

\subsection{O Objeto de Estudo: a Visão do Professor-tutor sobre a Adequabilidade do Material Didático de Cálculo I ao Estudo Remoto}

O curso de Licenciatura em Matemática da UAB/DEaD do IFCE é ofertado desde 2007, quando, através de uma portaria de nº 111/GDG de 21 de março de 2007, instituiu-se a implantação desse curso na modalidade a distância no IFCE.

O objetivo principal da criação desse curso foi "formar profissionais licenciados em Matemática para atuação na educação básica e suas diversidades culturais e sociais, por meio da pesquisa, da reflexão teórica e prática e da autonomia do sujeito em formação, considerando seu crescimento formativo e participativo como artifício de igualdade e democracia" (BRASIL, 2010, p. 28). Esse objetivo é solicitado, atualmente, pelo mercado de trabalho, o qual exige que o professor esteja atualizado com as tendências de seu tempo.

A fim de que isso ocorra, a base curricular para formação de um professor de Matemática, seja ela a distância ou presencial, deve ser pautada em pressupostos pedagógicos e matemáticos que se alinhem a essa exigência do mercado de trabalho. Com base nisso, a matriz curricular do curso de Licenciatura em Matemática semipresencial do IFCE se compõem de cinco eixos de formação: formação pedagógica; formação específica em Matemática; formação na área de tecnologia e comunicação; formação profissional; e formação de trabalhos científicos e sociocultural (BRASIL, 2010). 
É justamente no eixo de 'formação específica em Matemática' que se encontram as vinte e três disciplinas que têm o papel de dar o suporte teórico de conhecimento matemático que um futuro profissional dessa área precisa. Entre elas, está a disciplina de Cálculo Diferencial e Integral I (Cálculo I), a qual é ofertada no segundo semestre desse curso. Ela se compõe dos elementos explicitados no Programa de Unidade Pedagógica $(\mathrm{PUD})^{44}$.

Como se poderá perceber no Quadro 4, tem-se a apresentação dos conteúdos que devem ser explorados nessa disciplina, cuja ementa abrange todo o conteúdo de limites, derivadas e integrais em uma variável real. Pode-se analisar nesse quadro cada área explorada e se visualizar que o aluno deve, ao final da disciplina, ter contato com os conceitos estudados na disciplina de Cálculo I e domínio de todos os conceitos explorados.

No que tange ao conceito de limite, deve-se apresentar a noção intuitiva, definições, principais teoremas, propriedades operatórias e exemplos de aplicação desse relativo a esse conceito. Também em limite, o aluno deverá saber sobre o conceito importante dessa disciplina: Continuidade de uma função, o qual está diretamente ligado ao conceito de limites e, mais adiante, da construção de gráficos de funções em uma variável real.

Na parte de derivadas, faz-se um estudo desse conceito através, também, de uma abordagem intuitiva, usando-se da Geometria Analítica para determinar o significado da derivada como a inclinação da reta (de retas) tangente e sobre as taxas de variação. Propriedades operatórias, assim como regras e teoremas, também são apresentadas nessa parte. No entanto, o objetivo principal no estudo das derivadas de uma função é se utilizar dos conceitos estudados desse assunto e do conceito de limites (estudado anteriormente) para se construir gráficos de funções deriváveis em uma variável.

Na última parte, deve ser garantido ao aluno o estudo geral do conceito de integral, com estudo de definições, teoremas e principais aplicações em outras áreas do saber científico, como a Física.

Quadro 4 - Conteúdos explorados na disciplina de Cálculo I da Licenciatura em Matemática semipresencial do IFCE.

\section{LIMITES}

- Limite e Continuidade de funções de uma variável real - O limite de uma função real

\footnotetext{
${ }^{44}$ Esse PUD se encontra no Anexo I ao final dessa pesquisa.
} 


\begin{tabular}{|c|c|c|}
\hline & ० & $\begin{array}{l}\text { - Noção intuitiva de limite } \\
\text { - Definição e exemplos } \\
\text { - Propriedades operatórias } \\
\text { - O Teorema do Confronto dos Limites } \\
\text { - Limites infinitos e limites no infinito. } \\
\text { Continuidade de funções reais } \\
\text { - Noções intuitivas de continuidade } \\
\text { - Definição e exemplos } \\
\text { - Propriedades operatórias } \\
\text { - O Teorema do Valor Intermediário }\end{array}$ \\
\hline DERIVADAS & $\begin{array}{r}\text { A De } \\
\circ \\
\\
\\
\end{array}$ & $\begin{array}{l}\text { vada de uma função de uma variável real } \\
\text { Introdução } \\
\text { - O quociente de Newton e a definição de } \\
\text { derivada } \\
\text { - } \text { Interpretação da derivada como inclinação de } \\
\text { retas tangentes a taxas de variações } \\
\text { - Propriedades operatórias } \\
\text { Derivadas de funções elementares } \\
\text { - Funções polinomiais } \\
\text { - Funções trigonométricas } \\
\text { - Funções exponenciais e logarítmicas } \\
\text { - Funções hiperbólicas } \\
\text { A Regra da Cadeia } \\
\text { - Derivação de funções compostas } \\
\text { - Derivação Implícita } \\
\text { - Taxas de Relacionadas. } \\
\text { A Regra de L' Hospital } \\
\text { Estudos de pontos críticos } \\
\text { - Problemas de otimização. } \\
\text { O Teorema do valor médio } \\
\text { Estudo do comportamento do gráfico de funções } \\
\text { mediante o auxílio das derivadas. }\end{array}$ \\
\hline INTEGRAIS & $\begin{array}{r}\text { - A int } \\
\text { } \\
\quad \\
\quad\end{array}$ & $\begin{array}{l}\text { Inal de Riemann } \\
\text { Introdução } \\
\text { - Noção intuitiva de integral de uma função real } \\
\text { - Definição e exemplos } \\
\text { - Propriedades operatórias } \\
\text { A Integral Definida } \\
\text { - A primitiva de função } \\
\text { - O Teorema Fundamental do Cálculo } \\
\text { - Cálculo de áreas de figuras planas } \\
\text { Técnicas de Integração } \\
\text { - Mudança de variável } \\
\text { - Integração por partes }\end{array}$ \\
\hline
\end{tabular}




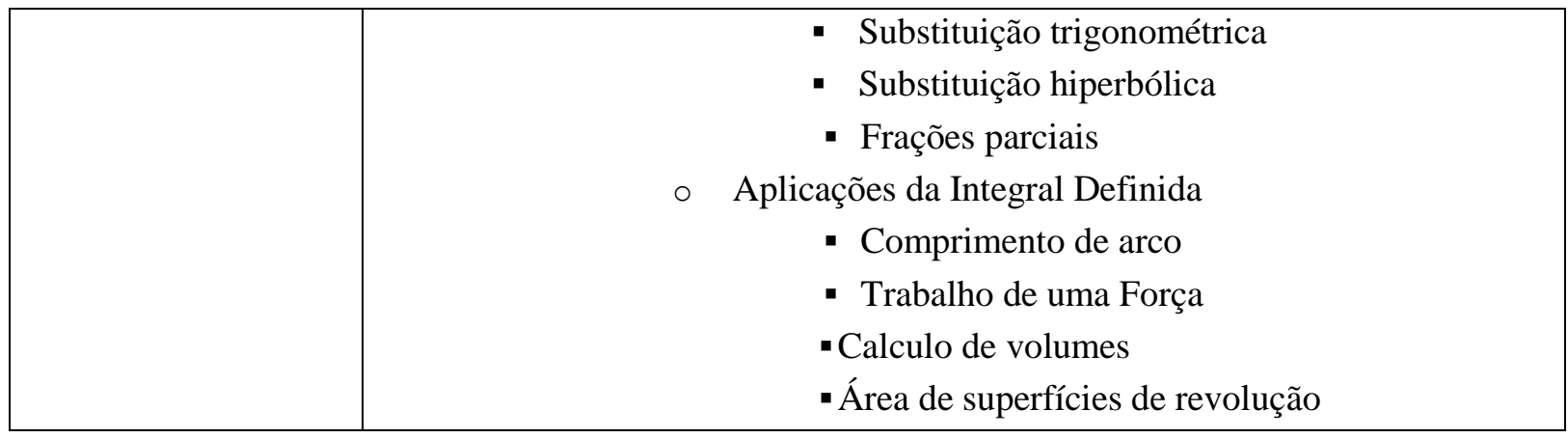

Fonte: PUD de Cálculo I (ANEXO I).

O material didático da disciplina de Cálculo I que foi produzido na UAB/DEaD do IFCE, pelo professor-conteudista, deve atender a todos esses conteúdos, enquanto o professor-tutor que aplica a disciplina de Cálculo I evidenciaria se esse MD está adequado para a apropriação desses saberes.

Em EaD, o conteúdo é trabalhado e modificado para ser apresentado como forma de um MD que, dependendo da carga horária da disciplina, é dividido em aulas, as quais, por sua vez, são subdividas em tópicos. No caso de um MD de Cálculo I, são 10 aulas, já que sua carga horária é de 100 horas/aula. Cada aula pode ser dividida em certo número de tópicos para serem apresentadas no AVA Moodle do IFCE45 em forma de material didático digital ou em material didático impresso.

No anexo II, pode-se verificar o sumário do MD impresso de Cálculo I, como se pôde ver a divisão dos assuntos abordados no Quadro 4. Nota-se que a primeira aula faz uma breve revisão do assunto de função que outrora já fora um conteúdo estudado em outra disciplina.

As aulas dois e três se dedicam ao estudo de limites e suas propriedades. Já as aulas quatro a sete são dedicadas ao estudo de derivadas e suas definições e propriedades, com atenção especial para a aula sete, na qual se pode verificar que é dada ênfase ao "Estudo do comportamento do gráfico de funções mediante o auxílio das derivadas", por ser o objetivo principal do estudo de derivadas. O conceito de integração é dado da aula oito até a aula dez, com o estudo de definições, propriedades, regras, e aplicações desse conceito em outras áreas da Ciência.

\footnotetext{
${ }^{45}$ Atualmente o AVA moodle do IFCE pode ser acessado através do seguinte endereço eletrônico http://virtualnovo.ifce.edu.br/login/index.php
} 
A seguir se explanará como se deu a pesquisa de campo, qual o tipo de metodologia foi aplicado a esse trabalho e qual a visão dos professores tutores sobre o MD de Cálculo I produzido na UAB/DEaD do IFCE.

\subsection{A Pesquisa de Campo}

Os procedimentos metodológicos se pautaram em estudo de caso com técnicas de coleta de dados caracterizados por serem de observação direta extensiva. Utilizou-se como técnica a aplicação de um questionário constituído por perguntas aos professores-tutores selecionados a participarem de entrevistas para exporem sua visão sobre o objeto de análise. Para a realização da pesquisa de campo, foram realizadas entrevistas individuais com os três sujeitos participantes que atuaram como professores-tutores na disciplina de Cálculo I nos períodos de 2013.1 e 2014.1. A seguir descreve-se o instrumento utilizado e os sujeitos envolvidos na pesquisa.

\subsubsection{O instrumento utilizado}

As pesquisas qualitativas, ao contrário das quantitativas, procuram extrair análises mais precisas dos dados fornecidos e colhidos da ação em campo. Sendo assim, utilizando esse tipo de metodologia faz-se pensar em como se dará as análises dos discursos narrativos advindos dos sujeitos estudados.

O instrumento predominantemente utilizado como técnica de investigação na ação em campo foram as entrevistas realizadas com os sujeitos envolvidos na pesquisa. A utilização dessa técnica de investigação requer, por parte do pesquisador-entrevistador, um planejamento realizado com certa antecedência.

O pesquisador, que assume o papel de entrevistador, precisa ter em mente que esse planejamento deve abranger desde a seleção dos participantes; ao local onde será 
realizada a entrevista; o momento adequado; o roteiro de perguntas; a testagem da qualidade do gravador; e, principalmente, a ética para com os participantes dessa entrevista.

Em nenhum momento, o participante deve se sentir obrigado a dar uma entrevista. Ele tem que ser convidado a participar dessa ocasião para que assim possa apresentar a sua opinião ou sua perspectiva sobre o assunto, o qual deve ser abordado com tranquilidade.

O pesquisador-entrevistador tem que deixar claro para o entrevistado sobre a não obrigatoriedade da participação na entrevista e também esclarecer ao entrevistado que ele terá o direito ao seu anonimato. Portanto, o pesquisador-entrevistador só pode continuar com a entrevista se o entrevistado der consentimento sobre a sua participação.

Há alguns tipos de entrevistas que são utilizados em pesquisas qualitativas. Optou-se aqui por se fazer uma entrevista semiestruturada, na qual o pesquisadorentrevistador deve ser guiado por um roteiro de questões abertas o qual lhe permite uma organização flexível e mais extensa das perguntas à medida que as informações vão sendo apresentadas ao entrevistado (BELEI et al, 2008).

O roteiro de perguntas realizadas nessa pesquisa foi composto de cinco perguntas abertas as quais tratavam sobre a transposição didática mencionada no capítulo anterior (como foi apresentada, a Sequência FEDATHI foi tida como um tipo de transposição didática). Sendo assim, as quatro primeiras perguntas desse questionário estavam relacionadas às etapas explicitadas nessa sequência (ver apêndice I). As outras perguntas surgiram no decorrer das entrevistas com os participantes. Naturalmente isso ocorreu, pois à proporção que os entrevistados iam fornecendo respostas para as perguntas pré-concebidas, outras questões relevantes que iam surgindo também.

Para seleção de participantes para a pesquisa, seguiram-se critérios que serão explicitados a seguir, os quais deram uma direção considerável ao trabalho.

\subsubsection{Os sujeitos da pesquisa: os professores-tutores}


Os sujeitos estudados nessa pesquisa foram os professores-tutores que já atuaram na disciplina de Cálculo I e tiveram contato com o MD dessa disciplina em suas duas últimas ofertas, em 2013.1 e 2014.1.

Foram convidados sete professores que atuaram como tutores na disciplina de Cálculo I da Licenciatura em Matemática semipresencial no período já citado. Desses, somente três aceitaram o convite para a entrevista e para expor sua visão sobre a adequabilidade e qualidade do MD de Cálculo I. Dois eram licenciados em Matemática, com formação nessa área, e um com formação em Estatística, cuja especialização se diferenciava, pois as áreas do saber eram diversas: ProEja; Ensino de Matemática; e Metodologia do Ensino Fundamental e Médio. Além disso, também dois dos sujeitos entrevistados têm mestrado profissional em Ensino de Ciências e Matemática.

Com relação à faixa etária, no grupo entrevistado, os sujeitos tinham 33, 47, e 40 anos de idade ${ }^{46}$. Quanto ao tempo de atuação no ensino superior, independente da modalidade de ensino, a faixa de variação oscilava entre um a dez anos de experiência acadêmica para esse nível de ensino.

Para melhor analisar as narrativas de cada entrevista e a fim de garantir o anonimato desses quatros participantes entrevistados, eles são identificados com seus perfis:

Figura 11 - Formação acadêmica de cada professor-tutor entrevistado.
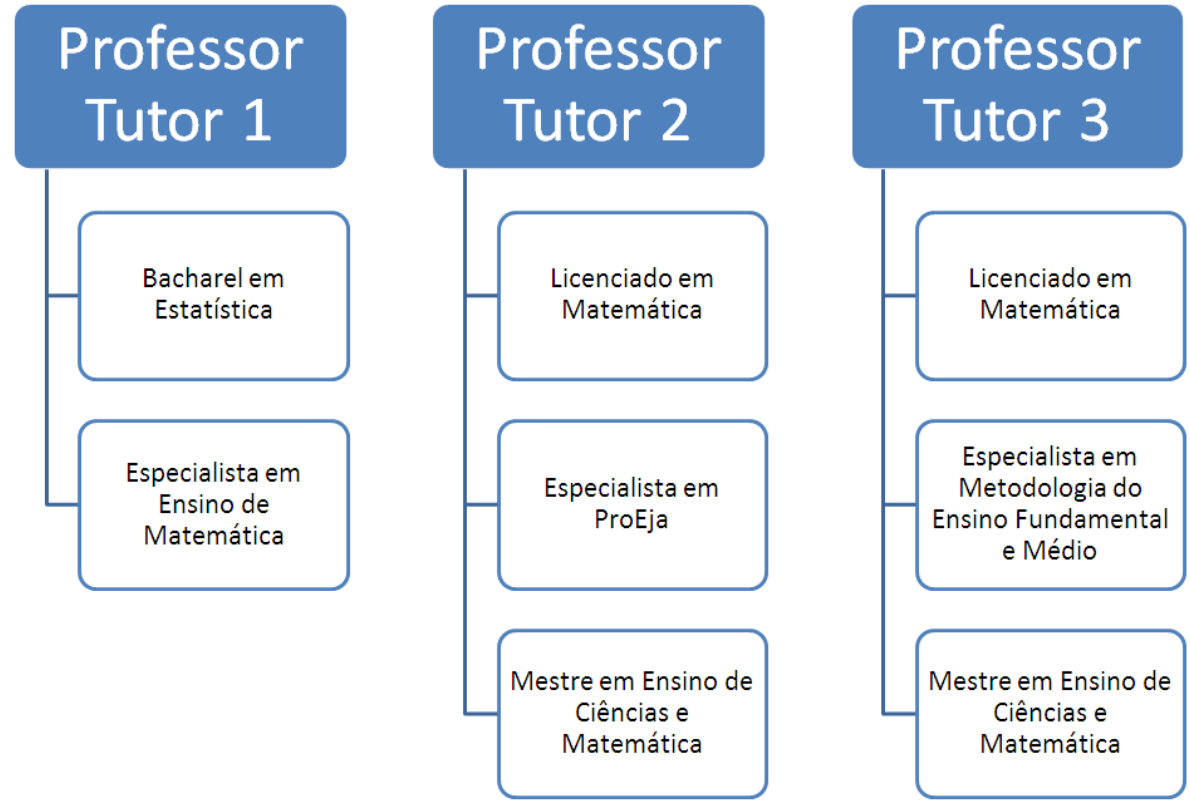

Fonte: Autoria da pesquisadora (2014).

\footnotetext{
${ }^{46}$ Respectivamente, cada um foi identificado como sendo: professor-tutor 1, professor-tutor 2, e professor-tutor 3.
} 
Cabe ressaltar que o 'professor-tutor 1' lecionou a disciplina de Cálculo I uma vez; já o 'professor-tutor 2' atuou nessa disciplina duas vezes; enquanto o 'professor-tutor 3' foi convocado a atuar nessa disciplina três vezes.

No próximo capítulo, foram feitas as análises das narrativas desses três entrevistados para verificar se em suas visões percebiam a adequação do conteúdo de Cálculo I à aprendizagem remota. Intencionava-se saber se houve presença de uma transposição didática, em específico a Sequência FEDATHI, no MD de Cálculo I produzido pelo IFCE para o curso semipresencial de Licenciatura em Matemática. 


\section{A VOZ DO PROFESSOR-TUTOR SOBRE O USO DO MATERIAL DIDÁTICO DE CÁLCULO I: O CASO DO IFCE}

Esse capítulo deve verificar se a Sequência FEDATHI está evidenciada no material didático de Cálculo I que foi produzido pelo IFCE para o curso semipresencial de Licenciatura em Matemática, a fim de conhecer a visão do professor-tutor sobre adequação desse material didático à modalidade semipresencial de ensino superior. Para que isso ocorra, fazem-se tanto análises das narrativas realizadas através das entrevistas com três professorestutores que atuaram na disciplina de Cálculo I desse curso nos períodos de 2013.1 e 2014.1, como também outras questões que devem ser discutidas ainda nesse capítulo.

\subsection{O Olhar do Design Instrucional na Problemática da Pesquisa}

Como foi colocado no capítulo três dessa pesquisa, o Design Instrucional Contextualizado (DIC) lida com situações didáticas que realçam o processo de análise, design e desenvolvimento, implementação e avaliação de um Material Didático (MD), o qual deve favorecer a contextualização no processo de aprendizagem do aluno.

Sabe-se que o objeto de investigação dessa pesquisa, o material didático de Cálculo I, era um produto pronto, porém não acabado, por isso se visualizou que as etapas que poderiam se enfatizar nesse processo seriam as seguintes: de 'design e desenvolvimento'; e de 'avaliação', para se fazer uma sondagem do que poderia ser melhorado no material.

A etapa de 'design e desenvolvimento' foi revista, pois, como explicado anteriormente, ela lida com o processo didático da produção de um MD. É nessa etapa que a seleção de metodologias a se utilizar na abordagem no MD é revista para que se possa verificar se está adequado ao público-alvo a que se destina.

Ao se colocar a metodologia de ensino, Sequência FEDATHI, como um tipo de transposição didática, visualizou-se que essa etapa foi essencial para o trabalho, já que foi 
possível analisar se os saberes docentes acadêmicos e científicos estavam sendo, adequadamente, transpostos de forma didática para os alunos no MD de Cálculo I, o que era uma incógnita para a pesquisa.

A etapa de 'avaliação' entra novamente nesse cenário de investigação para saber como o produto final estava, qualitativamente, na perspectiva de quem usa - na ocasião eram o aluno e o professor-tutor. No entanto, como se sabe, a Sequência FEDATHI é uma metodologia de ensino, então se priorizou analisar somente a perspectiva do professor-tutor que, possivelmente, usou o MD de Cálculo I e poderia, com certa propriedade, apontar e colaborar no fornecimento de informações que pudessem esclarecer se a presença desse tipo de transposição didática estava ocorrendo no MD dessa disciplina.

Cabe lembrar que é nessa etapa de avaliação que, com as orientações e opiniões (advindas das entrevistas realizadas com os professores tutores que atuaram na disciplina de Cálculo I), se enxergariam possíveis reorientações, adaptações, reconstruções na melhoria desse MD. Para executar isso, fez-se, a seguir, uma análise das narrativas advindas das entrevistas realizadas com esses professores-tutores para saber se havia presença das etapas da Sequência FEDATHI no MD de Cálculo I. Outras questões que foram abordadas na entrevista mereceram ser destacadas e apresentadas.

\subsection{A Presença da Sequência FEDATHI no Material Didático de Cálculo I Produzido pelo IFCE: Análise das Narrativas dos Entrevistados}

Um MD para EaD segue padrões bem definidos de produção para que seja acessível e inteligível para o público-alvo a que está direcionado: o aluno que estuda a distância. Ele, também, tem o papel de desenvolver competências de aprendizagem nesse discente. No entanto, para além desse padrão, um MD que é produzido para uma área específica do saber precisa de metodologias de ensino que estejam adequadas a essa área e que enfatizem características próprias do meio. No caso específico de um MD de Matemática para ensino superior, uma metodologia de ensino deve estar adequada aos objetivos de aprendizagem dessa área. 
Com base nessa ideia, através das narrativas realizadas nas entrevistas com os professores-tutores que atuaram na disciplina de Cálculo I, no ano e período de 2013.1 e 2014.1, se verificou se houve a presença da metodologia de ensino Sequência FEDATHI no material didático que foi produzido para essa disciplina.

Cabe lembrar que a metodologia de ensino Sequência FEDATHI, descrita no capítulo 3 dessa pesquisa, foi discutida em Souza, o qual entende que:

(...) a Sequência Fedathi propõe que, ao deparar um problema novo, o aluno deve reproduzir os passos que um matemático realiza quando se debruça sobre seus ensaios: aborda os dados da questão, experimenta vários caminhos que possam levar à solução, analisa possíveis erros, busca conhecimentos para constituir a solução, testa os resultados para saber se errou e onde errou, corrige-se e monta um modelo. (SOUZA, 2013, p.18).

Observa-se que, nesse trecho, toda essa trajetória da busca da solução é realizado através de um 'caminho' que é semelhante a de um de matemático profissional e deve ser percebido em um MD de matemática. Como o aluno de EaD estará estudando só, os conceitos apresentados devem instigá-lo inteligivelmente, para que tenha uma experiência matemática significativa, na busca da solução de algum problema apresentado.

Cabe, portanto, ao professor, no caso o conteudista, fazer uma mediação de ensino e instigar o aluno a experimentar essas situações matemáticas significativas. É justamente então que se dá o processo relacional entre "aluno-saber-professor", uma vez que essas três esferas estão, a todo o momento, no processo interacional entre si, no qual o professor (re)constrói, na perspectiva de quem está aprendendo, o saber que outrora foi construído por outras mentes matemáticas.

Sendo assim, como já foi citada, a Sequência FEDATHI constitui-se em quatro etapas, a saber:

Figura 12 - As quatro etapas da Sequência FEDATHI.

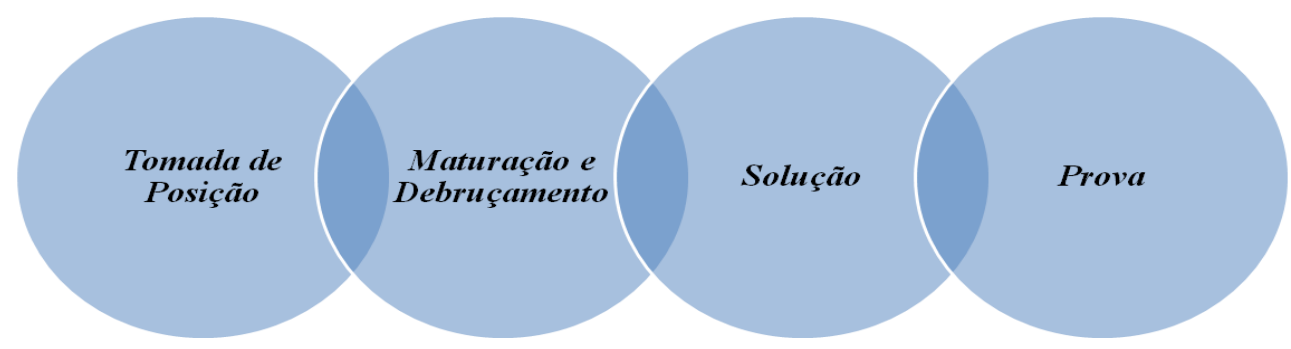

Fonte: Moreira (2009). 
Segundo Souza (2013), a primeira etapa, Tomada de Posição, consiste em fazer com que um problema, generalizável, seja apresentado para o aluno com o objetivo de desenvolver habilidades específicas do conhecimento a ser ensinado e que está sendo adquirido. A segunda etapa, Maturação e Debruçamento, é destinada à discussão entre professor e aluno acerca do que foi apresentado como problema no início. Aqui deve haver uma compreensão e identificação das variáveis que estão envolvidas no problema.

Já a terceira etapa, Solução, faz uma organização e apresentação dos esquemas e modelos com o intuito de solucionar o problema. Durante essa etapa, há estímulo às trocas de ideias, opiniões e discussões sobre os conceitos que estão sendo adquiridos. Na quarta e última etapa, tem-se a Prova, que tem o papel de formalizar o modelo matemático extraído da situação problema inicial (SOUZA, 2013).

A partir dessas premissas teóricas, o questionário produzido (apêndice I) para a entrevista com os professores-tutores, foi formado por cinco perguntas, no qual as quatro primeiras estavam relacionadas com cada etapa da Sequência FEDATHI, como pode ser visto na Figura 13.

Figura 13 - As etapas da Sequência FEDATHI e sua relação com cada pergunta do questionário da entrevista.

\section{Tomada de Posição}

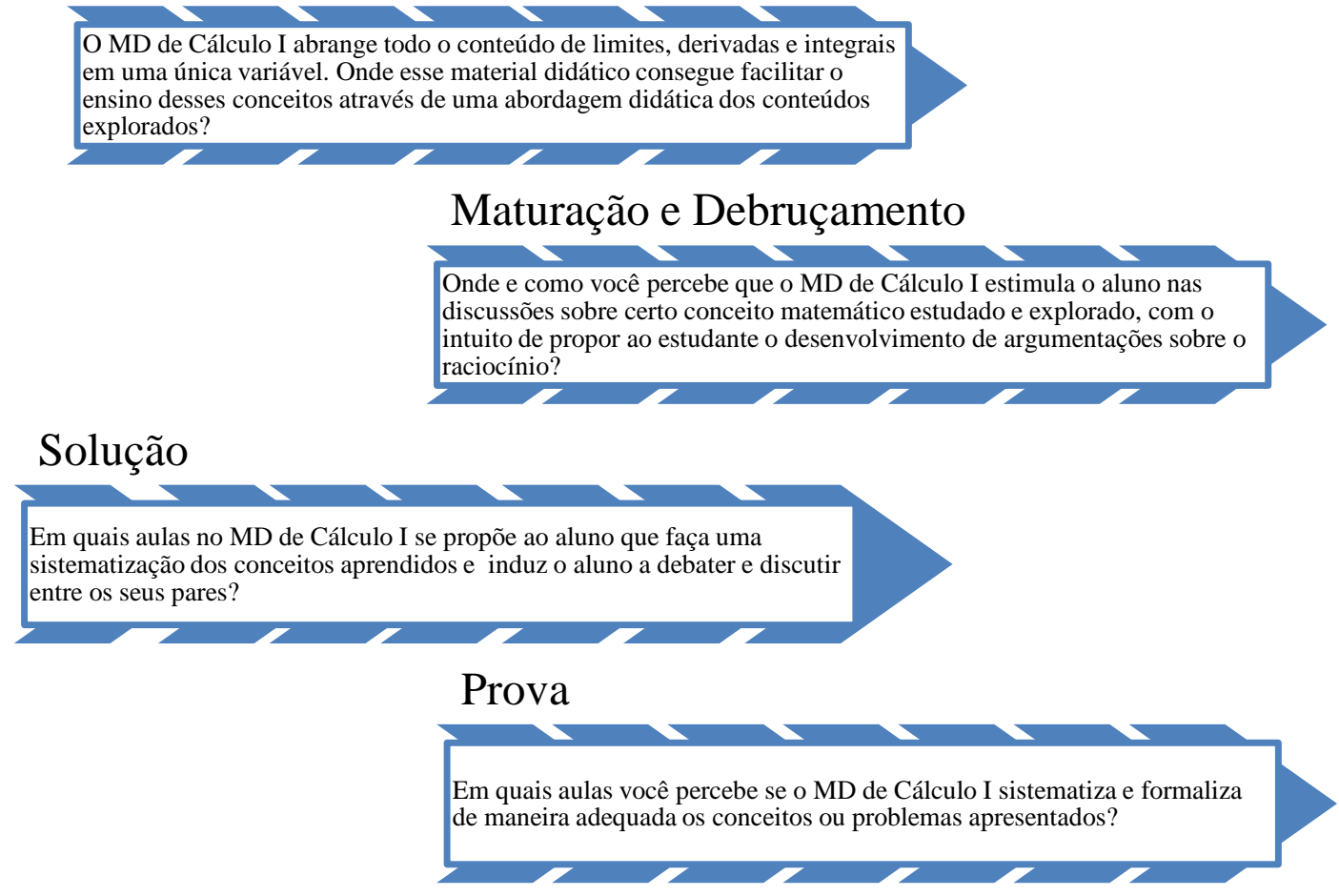

Fonte: Autoria da pesquisadora (2014). 
Para cada pergunta, o entrevistado respondia, livremente, sobre o assunto a que estava relacionado. As narrativas dos três entrevistados variavam para cada um, ora divergindo, ora convergindo, ora completando.

Como se pode ver na Figura 13, a primeira pergunta realizada com os professorestutores estava relacionada à etapa de Tomada de Posição. O objetivo desse questionamento era saber como se dava a abordagem didática dos conceitos trabalhados no MD de Cálculo I.

De acordo com as narrativas transcritas e apresentadas nos apêndices II, III e IV, pode-se colher dados para análise de cada resposta fornecida pelos participantes dessa pesquisa. Percebe-se, na análise das respostas, que nas três áreas que o Cálculo abrange, limite, derivada e integral, logo o MD introduz o conceito de forma mais didática, quando se abordam as teorias relativas à derivada e integral de uma função, como visto nos dois trechos das falas destacados a seguir:

Eu acho que é mais a de integral. Até porque a de integral se torna um pouquinho mais fácil pra eles depois, né? (Professor-tutor 1)

Ele consegue, ele tá bem didático, bem. (...) Eu percebo que ele consegue, ele dá a definição gráfica, né? De derivada, ele dá a visão gráfica, começa do gráfico. (...) Ele deixa bem claro que a derivada é o coeficiente igual ao da reta tangente, certo? Ele faz bem. (...) Como qualquer outro livro, ele faz bem essa introdução. Ele deixa bem claro para o aluno que é importante saber que... O que é uma derivada? É o coeficiente angular, né? Da reta tangente no ponto (...). Quando ele chega em integral, também, ele explica bem o teorema fundamental do cálculo. O método dos trapézios, ele deixa bem explicado. (Professor-tutor 2)

Observa-se que, nas falas desses tutores, no MD de Cálculo, o professorconteudista conseguiu explicar, de forma adequada, os conceitos de derivada e integral. Podese notar que o professor-tutor 2 , principalmente, manifestou sua opinião com uma maior riqueza de detalhes sobre essa informação.

Percebe-se que ele fala das ideias ('a visão gráfica', 'reta tangente', 'coeficiente angular') as quais estão associadas à construção do conceito de derivada, os quais instigam, indagam, fazem refletir sobre o desenvolvimento desse conceito. Isso faz toda diferença para ele, pois é nessa "parte aqui de integral e derivada é bem [que está bem] explorada", ou seja, esses conceitos que foram mencionados estão satisfatórios.

Isso vai ao encontro do que Souza (2013) defende, quando afirma que o professor deve instigar no aluno a reflexão, a indagação, a formulação de hipóteses com o objetivo de 
encontrar uma solução para um problema antes apresentado. Souza ainda explica que esse novo conceito o qual está sendo introduzido, pode ser realizado através de vários meios: situação-problema; jogo; pergunta; material concreto; experimentações de softwares; entre outros tipos de recursos que levem o aluno a busca pela resolução do problema.

No entanto, se a abordagem desse problema não for realizada e apresentada de uma forma didática, como ainda aponta Souza (2013), a compreensão desse novo conceito que está sendo introduzido pelo MD pode se tornar complexa e pouco inteligível para o discente. Para ilustrar tal fato, o professor-tutor 3 apontou essa característica como um fator de importância para a produção de um MD:

\begin{abstract}
A abordagem está muito complexa, como eu disse no início, muito complexa. Se fosse um aluno de bacharelado, talvez de matemática, a linguagem é muito complexa. Poderia ser uma linguagem mais simples, entendeu? (...). Poderia, poderia ser. Num é que vá fugir dos conceitos, mas uma linguagem mais simples para o aluno que tá lendo, entender. A abordagem é muito complexa, não sei por quê... Pra quem estuda sozinho, a abordagem é um pouco complexa. (Professortutor 3).
\end{abstract}

Essa narrativa do professor-tutor 3 está em sintonia com que Souza discute sobre a adoção, pelo professor-conteudista, de uma linguagem acessível ao seu público-alvo, linguagem esta que deve ser clara, sem, contudo, deixar de lado as especificidades da linguagem materna, a linguagem matemática.

Há também outro ponto a ser discutido aqui, já que as narrativas de dois desses tutores convergiram para uma mesma constatação: a parte a que é destinada a introdução do conceito de 'limites' não está adequada didaticamente. Segundo eles:

O problema mais é na parte de limite, que teria que tá um pouquinho [melhor explicado]... Porque, se eles não entenderem o que é limite, aí depois complica bastante (Professor-tutor 1).

Agora, a parte introdutória de limite é que eu acho que devia ser em funções, porque antecede [as funções antecedem] essa parte porque é importante pra essas duas aqui e deixa a desejar, na minha opinião (...). É uma falha, é... Eu acho assim, falta só completar limites, tá entendendo? (Professor-tutor 2).

É justamente na parte de limites que se resume toda a base do Cálculo, pois, em qualquer livro que se estude sobre esse assunto, a introdução é feita, de diversas formas, dependendo do autor, através de limites. 
Cabe lembrar que, no capítulo 2 dessa pesquisa, descreveu-se sobre o ensino do Cálculo nos livros didáticos adotados nas instituições de ensino superior, atualmente. Nota-se no Quadro 2, exposto naquele capítulo, que a introdução de limites varia de autor para autor, pois há quem goste de fazer uma abordagem mais aritmética que geométrica ou algébrica, ou vice-versa.

A segunda pergunta, como mostra a Figura 13, está relacionada com a etapa de Maturação e Debruçamento, na qual, segundo Souza (2013), deve haver a compreensão e delineamento, por parte do aluno, dos possíveis caminhos para a solução do problema apresentado. É nessa etapa que há a discussão desse problema entre os envolvidos no processo: professor (conteudista) e aluno (leitor). É importante que haja presença de questionamentos, de ambas as partes, para instigar, refletir, levantar hipóteses, estimular, esclarecer, orientar sobre a solução da situação-problema em questão (SOUZA, 2013).

Com base nisso, pode se analisar que na entrevista realizada com os tutores, dois desses puderam dar uma resposta que se pôde considerar que se enquadrem nessa perspectiva, como pode ser visto a seguir, na fala do professor-tutor 2 :

\begin{abstract}
A parte que ele mesmo, é nessa parte aqui de, de... Comportamentos [do gráfico de uma função], né? Essa parte aqui da... aula 7. (...). Na aula 7, porque nessa aula aqui ele vai usar todo o conhecimento da aula 1,2,3,4,5,6. Certo? Aqui, ó, no estudo de comportamento [gráfico de uma função], ele vai usar... derivada primeira, derivada segunda... Ele vai estudar. Quando ele fala (...) derivada primeira, ele tem que aplicar... Se cair uma função no segundo grau, ele tem que saber estudo do sinal na função do segundo grau. Entendeu? Aí, se cair uma função do $1^{\circ}$ grau, aí ele tem que saber estudo do sinal da função do primeiro grau. Então, tá entendendo? (...) Aqui, ó, nessa aula 7, encaixa nisso aqui, certo? Todo, tudo o que ele foi estudando daqui pra trás, limite, continuidade, derivada, ele vai usar na aula 7... Olha, é esse estudo de comportamento do gráfico das funções. Ele vai estimular o aluno, exatamente, a voltar por que... Ele vai construindo. Quando ele chega aqui, aí ele vê e... O que é que estimula. Porque ele vai ver o estudo do sinal, ele volta pro capítulo 1 . Porque ele vai ver que o estudo do sinal da função do segundo grau vai lá no capítulo 1 procurar. Aí, ele vai ver derivada: "Ah, rapaz, derivada da função seno, cosseno, aí eu vou voltar o capítulo de derivada". Tá entendendo ou não? Vai estimulando ele a [voltar aos outros capítulos]... (Professor-tutor 2).
\end{abstract}

A aula 7, mencionada nesse trecho, trata do seguinte assunto: "estudo do comportamento do gráfico de funções mediante o auxílio das derivadas" (ver anexo II). Com a constatação evidenciada na fala do professor-tutor 2 , que tentou explicar que, para o aluno ter o domínio das variáreis envolvidas nessa 'aula 7', na qual é pedido para construírem gráficos de uma função com base nos conhecimentos prévios de limites e derivadas, ele tem 
que já ter compreendido esses conceitos, que perpassaram por outras aulas, que estão, intimamente, ligadas entre si, como pode-se observar na Figura 14.

Figura 14 - Relação entre a aula 7 e as outras primeiras aulas do MD de Cálculo ${ }^{47}$.

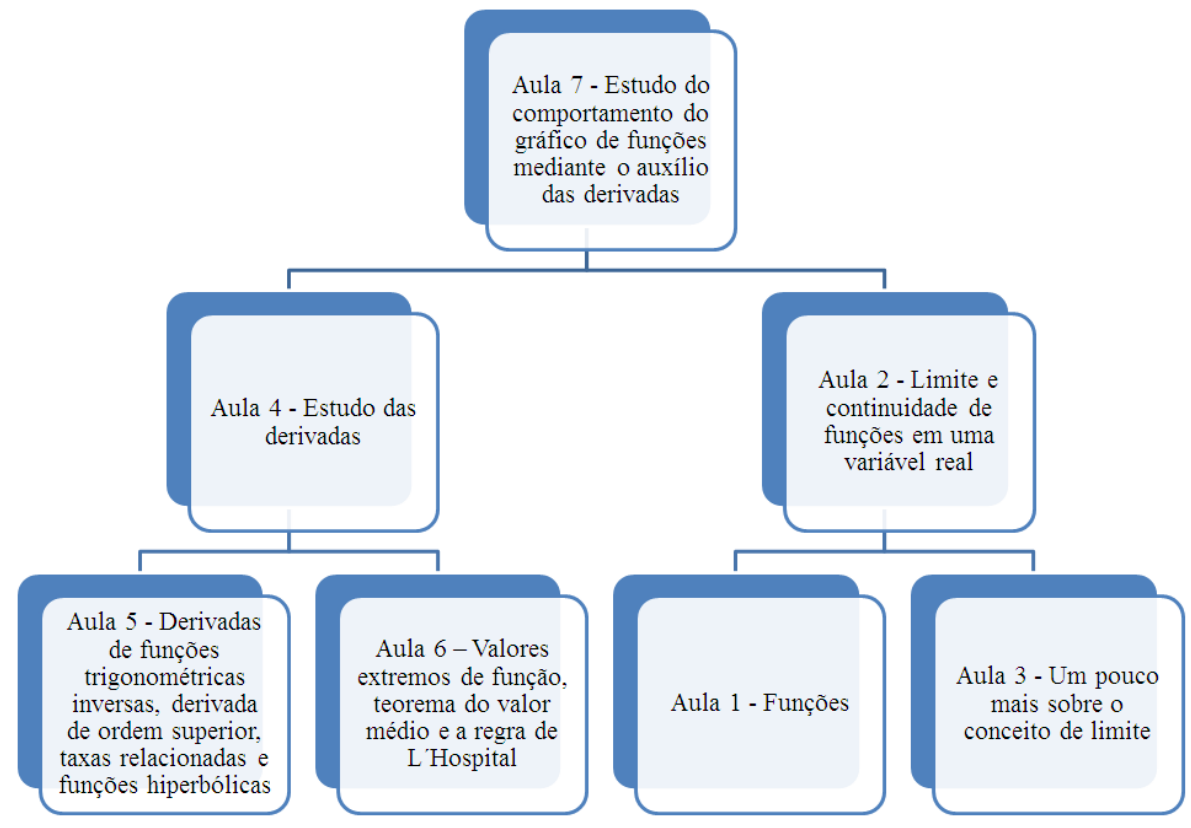

Fonte: Autoria da pesquisadora (2014).

Na tentativa de construir os gráficos de diversos tipos de funções apresentadas na aula 7, é que o aluno, segundo o professor-tutor 2 , se sente estimulado a voltar às outras aulas para tirar dúvidas sobre certos conceitos que não ficaram claros, refletir e levantar hipóteses sobre os conceitos-chave, os quais lhes dão a base suficiente para fazer a construção desses gráficos. Isso vai de encontro ao que Souza (2013) pensa e que foi exposto, pois, ainda segundo o Professor-tutor 2, se "ele não sabe continuidade, se ele não estudou bem derivada, ele não vai fazer a aula 7" que solicita a compreensão desses conceitos para a construção de gráficos de funções. O aluno fica desestimulado a ir em busca de solucionar o problema.

Em um terceiro momento, a terceira etapa da Sequência FEDATHI, a Solução, foi mencionada na entrevista, com sua pergunta equivalente, como mostra a Figura 13. Como já foi discutido, nessa etapa, há um estímulo para a troca de ideias, opiniões e discussões sobre o conceito que foi apresentado e que, dependo do assunto, faz menção a outros conhecimentos

\footnotetext{
${ }^{47}$ Com base tanto no anexo II dessa pesquisa que se trata do sumário do MD de Cálculo I, como no que foi dito pelos professores-tutores.
} 
adquiridos em outras etapas. Segundo Souza (2013), o professor deve, a todo o momento, indagar, estimular, solicitar que o aluno explique e justifique o modelo matemático que está sendo construído nesse momento. O professor deve indagá-lo para saber se o aluno soube usar "todas as variáveis do problema e se são suficientes para encaminhá-las à resposta procurada" (p. 29).

De acordo com esse pensamento, foi perguntado aos professores-tutores se no MD de Cálculo I havia a presença da sistematização dos conceitos aprendidos pelo aluno, com o intuito de fazer com que buscasse compreender o que estava sendo aprendido e se, no material, havia a presença de convites à discussão de algum conceito. Dos dados colhidos, foi averiguado que as respostas mais coerentes foram as do professor-tutor 2 , o qual salientou:

(...) ele tiver aqui na, na derivada, na aula 4, ele debate a aula 1. (...) Porque, quando ele começa a estudar derivada, como eu digo lá, quando... O maior problema é 0 sobre 0 , ou seja, uma indeterminação. Então, ele vai ter que aprender novamente a discutir aquilo que eu tô lhe falando. (...) De polinômios, de que tá faltando (...). É porque, é... Se ele tem lá um polinômio, uma... uma função do $2^{\circ}$... Uma função de grau 2, que a forma fatorada da função do segundo grau é a (x-a).(x-b), ele vai discutir com o aluno, com o colega, né? Exatamente com eles. (Professor Tutor 2).

Nessa explicação, o professor-tutor 2 estava falando sobre que a aula 1 deveria, além de apresentar funções, fazer uma exploração sobre o estudo de polinômios e sobre operações que se poderiam realizar sobre esse conceito, já que o aluno, a todo o momento, estará vendo operações com polinômios, principalmente a divisão, quando as variáveis são substituídas por valores numéricos.

No caso específico da divisão de polinômios, pode vir a zerar tanto no numerador quanto no denominador, o que causa uma indeterminação. Logo, se o aluno não souber fazer esse tipo de operação, ele não vai conseguir solucionar o problema.

Se no MD de Cálculo I não houver a presença de elementos que façam com que o aluno reflita sobre como pode resolver o problema através de conhecimentos prévios, dificilmente ele conseguirá realizar ou chegar à resposta final. O que vai ao encontro do que o Professor-tutor 3 também pensa sobre esse assunto, quando ele expõe suas ideias:

Principalmente, naquela parte de aplicações, certo, das derivadas. (...). Pronto. A aula 5, ó, certo - que tem as taxas relacionadas - e a aula 6 - que são os valores máximos, os valores mínimos, teorema do valor médio - essas duas aulas aqui, ó, são as que mais [Discutem sobre o assunto]... Certo? E também a 7, também, que é a parte do gráfico. Pronto. Essas três aulas aqui, ó: 5, 6 e 7, são, vamos dizer assim, o 'carro chefe' aqui, ó, do... [Ela chama o aluno pra fazer discussão sobre os 
conceitos que ele deveria ter aprendido em limites e também trazidos de outras épocas acadêmicas.]... Quando chega aqui que o 'engodo' começa, entendeu? Aqui o 'engodo' começa mais do que aqui porque aqui ele vai exigir dele uma bagagem grande. Além dele já ter visto limite, ele vai ter que ter uma base boa muito grande de funções, e essa aula 1 aqui é uma aula, assim, muito simplificada e de funções, apesar que o pessoal questiona bastante assim: "não, mas ele já viu a Matemática básica 1 , no $1^{\circ}$ semestre, porque o Cálculo 1 é só visto no $2^{\circ}$ ? Então ele já tem uma certa base, ele já estudou funções, todas as funções. Ele já fez a revisão, né? Na matemática básica 1", certo? Mas não é suficiente. Ele teria que ter uma base boa em cima disso aqui. (Professor-tutor 3).

Nesse momento, fica evidenciado o papel do professor como mediador do processo de ensino e aprendizagem, pois é imprescindível que "o professor [conteudista] motive os alunos a buscarem algumas formas de verificação dos resultados" (SOUZA, p. 30), fazendo, através de recomendações e indicações sobre o que deve ser importante, naquele momento, para que o aluno consiga aprender o que está sendo ensinado (daí a importância dos ícones em um MD). Ainda no tocante à fala do professor-tutor 3, ele enfatizou a importância dos ícones em dos momentos da entrevista:

Eu vejo, assim, mais, quando você tem naquele "Você Sabia?". Nessa parte aqui, é que dá, dá assim a sugestão do aluno tentar se aprofundar e tentar é... Ter ânimo de estudar, certo? Nesse material, quando ele tem a curiosidade de ver "Você Sabia que o lugar geométrico...?", aí isso aqui dá uma desperta... Eu acho que essa parte de "Você Sabia?" aqui, ela (...). Esses ‘iconezinhos' aqui, e alguns exemplos também despertam. (Professor Tutor 3).

A Prova, última etapa que foi indagada na entrevista, utilizando-se de um questionamento que também foi exposto na Figura 13, expõe que o professor deve fazer uma ligação entre o modelo apresentado pelo aluno e o modelo matemático científico (SOUZA, 2013).

No entanto, como se trata de um material didático para ensino a distância, e em específico de Matemática, o professor-conteudista vai ter que fazer essa ligação de forma que ele propõe estar no lugar do aluno para tentar visualizar os possíveis modelos que seriam apresentados pelo aluno, para logo depois elaborar um modelo matemático científico.

Na tentativa de saber se no MD de Cálculo I havia a possibilidade da presença dessa etapa, as narrativas fornecidas pelos professores-tutores apontaram o seguinte:

É... Eu, eu comparo sabe o quê? Eu comparo, né, a aula 4, né. Por exemplo, a aula 4 aqui, ele vai precisar desses três conceitos da aula 3. (...). Aula 1, 2 e 3. O estudo das derivadas, né, ó? Porque aqui você dizer que o (...) é tanto a aula 4 em relação às três primeiras, e a aula 7 em relação às 6 primeiras. (...). Na aula 7 , ele... vai acontecer 
isso aqui... Ele vai sistematizar e informatizar tudo o que ele aprendeu até aqui. Quando ele chegar nessa aula 4, ele vai ter que sistematizar o que ele aprendeu nas aulas 1, 2 e 3. (Professor-tutor 2).

$\mathrm{Na}$ verdade, era pra ser no final de cada aula ele ter isso aí, né? Mas vamos dividir assim, vamos dividir: Limite e Derivadas, certo? Em Limite, ele faz na aula 3, certo? É a sistematização final, porque, na aula 3, ele já tem que ter todos os conceitos pra estudar assíntotas, ou horizontais e verticais, a extensão que ele já estudou, e as propriedades. Então na aula 3, ele tem que ter aqui o resumo do limite, e na aula 7, o de Derivada, certo? O de Integral só é o começo, só a introdução, né? Na aula 8. Como esse curso já é de 100 horas, então são 10 aulas, então a aula 10 ele fecha, que são as aplicações da integral. (Professor-tutor 3).

Souza (2013) fala que, com o novo saber adquirido, ao final de um processo de aprendizagem, é compreendido e assimilado o conteúdo pelo discente, fazendo com que ele mesmo fique ciente de que é possível, através desse novo saber, deduzir outros modelos matemáticos que, dependo do assunto, podem ser ou simples e específicos, ou complexos e gerais.

Exemplo disso, como se pode extrair da narrativa do professor-tutor 2, é que, quando o aluno chega à aula 7 do MD de Cálculo que trata sobre construções de gráficos de uma função de uma variável real, ele deve saber que isso se deu por causa dos procedimentos percorridos em outras aulas - a aula 1 que estuda as funções; as aulas 2 e 3, o conceito de limites; as aulas 4, 5 e 6, o conceito de derivadas. Nota-se que, convergindo para a mesma conclusão, o professor-tutor 3 também fala dessa divisão sobre os conteúdos nas aulas.

Percebe-se que, na Sequência FEDATHI, essa última etapa constitui a sistematização e a finalização do todo o processo de aprendizagem diante de um problema matemático que é construído durante toda a disciplina de Cálculo I para esse curso semipresencial.

O aluno, ao final da disciplina, deve elaborar ou construir, mentalmente, modelos gerais sobre o conhecimento que está sendo construído, pois, como ele está estudando os conceitos de Limites, Derivadas e Integrais para funções de uma variável real, futuramente ele deverá saber aplicar todos esses conceitos em funções de ' $n$ ' variáveis reais, estudo esse realizado nas disciplinas de Cálculo II e III do mesmo curso de formação de professor de Matemática do IFCE, o que se pode ser percebido na fala de um dos professores entrevistados:

Aqui você está estudando a generalização para qualquer função. Então, quando ele conseguir, eu não vejo isso no material... Quando ele conseguir relacionar isso aí, 
esse estudo do cálculo e que possa, além de ele ver isso aí, possa abrir um leque... "Ah, então quer dizer que eu posso estudar, além disso, aqui", né? Veem outras possibilidades do Cálculo I, quando ele conseguir relacionar o que foi visto antes e que, futuramente, ele vai ver que são de duas, três e " $n$ " variáveis (...). Preparando a mente do aluno pra ele dizer assim: "Ah! Quer dizer que o que eu tô estudando aqui com uma [variável], eu vou ter a oportunidade de ver isso aqui com duas, com três variáveis, com mais de uma variável". Então, ele vai despertar... (Professor-tutor 3).

Outras questões sobre o MD de Cálculo I foram levantadas, além das que estavam diretamente relacionadas com a Sequência FEDATHI. Para finalizar o capítulo, se discutirá sobre algumas dessas questões, que valem o destaque nessa pesquisa.

\subsection{Outras Questões Relevantes Sobre o Material Didático de Cálculo I}

As perguntas que foram planejadas formalmente para essa entrevista totalizaram cinco. Além das quatro primeiras, que estavam relacionadas ao processo de ensino proposto pela Sequência FEDATHI, a quinta questão perguntava se "como e onde você percebe que o MD de Cálculo I consegue transformar os saberes científicos ensinados em saberes aprendidos?".

Dois professores-tutores relataram o seguinte:

Como a gente percebe? Através da prova, né? Seria isso? Porque a gente, pelas atividades em si... É porque na prova a gente sabe se ele realmente aprendeu alguma coisa. (Professor-tutor 1).

Seria, no meu ponto de vista, ele me mostraria que estaria aprendendo quando ele conseguisse relacionar aquilo que eu já lhe disse... Ele chegasse e conseguisse relacionar "Ah... Quer dizer que essa teoria aqui que eu tô estudando tem tudo a ver com o fundamental e com o médio", né? "Quer dizer que essas derivadas, essas construções desses gráficos, o cálculo dessas áreas...”, quando ele conseguir relacionar que essa teoria aqui é, está ligada ao que foi visto no ensino fundamental e no ensino médio, que eu, diga-se de passagem, eu não vejo aqui nesse material nenhuma relação com isso, assim... Pra ele chegar e mostrar que "o valor máximo da função do segundo grau...". Eu sempre digo: "Rapaz, aquele valor máximo, valor mínimo que você tá estudando está relacionado com o Cálculo I, está relacionado com o caso particular da função do segundo grau...”. (Professor-tutor 3).

O objetivo dessa pergunta era averiguar como, com todo esse processo de ensino, o professor-tutor conseguiu perceber que o aluno compreendeu esses conceitos. Na perspectiva do professor-tutor 1 foi através das avaliações presenciais dessa disciplina, que 
continua sendo um tipo de mensuração da aprendizagem para alguns professores. Já na perspectiva do professor-tutor $\mathbf{2}$, isso ocorre quando o aluno consegue visualizar que todos os conceitos estudados em Cálculo são também estudados no ensino fundamental e médio, porém, com um grau de complexidade mais avançado.

Outra pergunta que foi realizada no momento da entrevista estava relacionada às referências utilizadas no MD de Cálculo, principalmente nos livros que foram analisados no capítulo 2 dessa pesquisa: o Leithold, o Guidorizzi e o Stewart.

Segundo os professores tutores:

O Guidorizzi é muito didático, o Stewart é muito didático... Todos eles são bons! Mas interessante que o Leithold, ele sai mais, não sei por que. (...). Se aproxima do Leithold. (Professor-tutor 2).

Com o do Leithold, eu tenho certeza que não tá, certo? Com o do Leithold, no meu ponto de vista. Tá mais para o Stewart... O do Guidorizzi é um livro bom também, certo? E, assim, eu ainda acho, eu não sei, assim, qual é a linha de trabalho pra essa teoria ser tão pesada, entendeu? Porque, o Guidorizzi, ele tem uma teoria pesada, mas não é tão abstrata, tão complicada assim, entendeu? Tem uma teoria fácil de entender. Mas o Stewart, eu não costumo muito trabalhar com Stewart (...). (Professor-tutor 3).

Como pode ser visto, as opiniões divergiram para esses dois professores tutores. O Professor-tutor 2 apontou que o MD de Cálculo seguia mais o estilo do Leithold, enquanto que o Professor-tutor 3 disse que esse material estava mais próximo da abordagem realizada no Stewart. No entanto, o Professor-tutor 1 enfatizou em uma de suas falas que o MD estava mais para o estilo do Guidorizzi, por ser resumido demais.

Nesse capítulo, foram realizadas as análises das narrativas coletadas através das entrevistas realizadas com professores-tutores do curso de Licenciatura em Matemática semipresencial do IFCE sobre o MD de Cálculo I, com o intuito de verificar se a Sequência FEDATHI estava evidenciada nesse material didático.

Nas considerações finais se apresentarão as principais constatações gerais a que essa pesquisa chegou, com o objetivo de fazer uma análise da visão desses professores-tutores entrevistados para saber sobre a adequação do material didático de Matemática à modalidade semipresencial, para o ensino superior. 


\section{CONSIDERAÇÕES FINAIS E ENCAMINHAMENTOS FUTUROS}

A presente pesquisa teve o objetivo principal de analisar qual a visão do professor-tutor sobre a adequação do material didático de Matemática à modalidade semipresencial de ensino superior, em vista das necessidades de autoaprendizagem remota. Para isso, contou com objetivos específicos que dessem direção ao desenvolvimento dessa pesquisa.

Primeiramente, descreveu-se a evolução histórica do ensino de Cálculo no ensino superior no Brasil, realizada no capítulo 2, enfatizando-se aspectos importantes para essa ocorrência. Em seguida, foi realizada uma breve retrospectiva do ensino de Cálculo em duas instituições de ensino superior no Brasil desde a chegada da família real, em 1808, aos dias atuais. Essas duas instituições foram a Universidade Federal do Rio de Janeiro (UFRJ) e a Universidade de São Paulo (USP).

Como foi relatado, com a chegada da Família Real Portuguesa no Brasil à colônia do Rio de Janeiro, criou-se a necessidade de ter uma defesa militar o que obrigou a adotarem prioridades relacionadas a esse ponto. Umas delas estavam ligadas à profissionalização de pessoas para serviço militar, pois o Brasil era dotado de uma debilidade militar na defesa de suas fronteiras e em outros setores da sociedade brasileira. Por isso, foi criada uma instituição de ensino superior no Brasil que foi de grande importância para a formação de profissionais nas áreas de artilharia, geografia e topografia, o que ocasionou a criação da Academia Real Militar em 1810.

Nos primeiros anos, a grade curricular adotada nessa instituição era composta por diversas áreas da Matemática, incluindo o ensino de Cálculo Diferencial e Integral, que era dado no segundo ano, dos quatro anos, de um curso da academia.

A Academia Real Militar, nos decorrer dos anos, passou por várias mudanças de nome, até chegar a se chamar, em 1874, de Escola Politécnica do Rio de Janeiro. O curso de matemática ministrado (Curso de Sciencias Physicas e Mathematicas) passou, também, por mudanças no currículo, mas a presença do Cálculo Infinitesimal ainda estava presente na formação de seus alunos. Esse currículo vigorou por alguns anos. 
Já na Era Republicana, a politécnica do Rio de Janeiro passou novamente por uma nova mudança. Ela foi agregada, em 1920, a outras escolas de ensino superior que existiam na época - a Faculdade de Medicina e a Faculdade de Direito - para constituir a Universidade do Rio de Janeiro (URJ). Mais adiante, a URJ foi transformada na Universidade do Brasil (UBr), em 1937. Havia um dos setores da UBr, a Faculdade Nacional de Filosofia (FNFi), que era parte interessada na formação de Matemáticos no Brasil.

Em 20 de agosto de 1965, a UBr passou a se chamar Universidade Federal do Rio de Janeiro (UFRJ), mantendo as mesmas unidades de ensino. Inclusive, atualmente, o curso de Matemática da UFRJ é dado em quatro anos e é dividido em oito períodos, nos quais em três deles há espaço para o ensino do Cálculo.

Já a segunda instituição escolhida para análise da presença do ensino de Cálculo, foi a Universidade de São Paulo (USP). No início, em 1893 (ainda no Império), foi chamada de Escola Politécnica de São Paulo. Os primeiros cursos nessa escola foram criados para formar profissionais nas áreas da engenharia. Somente em 1934, foi criado a USP e a politécnica de São Paulo foi incorporada a ela com uma das unidades de ensino. Tal como ocorreu com UFRJ, um curso de formação de matemáticos se deu através da unidade de ensino chamado Faculdade de Filosofia, Ciências e Letras.

Atualmente, o curso de Matemática da USP é realizado em quatro anos e é dividido em oito semestres também. Entre as disciplinas ofertadas, há a presença do Cálculo Diferencial e Integral. Nesse capítulo, se fez uma análise comparativa dos principais livrostextos utilizados nessas instituições de ensino superior.

Em um segundo momento dessa pesquisa, procurou-se discutir o conceito de material didático de Matemática para ensino a distância. Foram explicitados elementos do design instrucional contextualizado, da composição de uma equipe de material didático para $\mathrm{EaD}$, e foi conceituado o que é um material didático tanto impresso como digital.

Lembrou-se de que o material impresso tem tradição histórica e que ele continua sendo um recurso bastante utilizado nas instituições que oferecem ensino a distância em todo o mundo. Outro tipo de material didático, o digital, apesar de ser recente, ganhou espaço nos últimos anos como um recurso didático que vem com a finalidade de facilitar e dinamizar o conhecimento que está sendo adquirido por quem estuda nessa modalidade de ensino. Vale ressaltar que as características pedagógicas que um material didático deve ter foram 
enfatizadas nessa pesquisa. Essas características são sistematização e organização do conteúdo; linguagem; e aprendizagem centrada no discente.

O conceito de Transposição Didática veio para dar respaldo a tudo que foi apresentado anteriormente sobre o material didático e, trazê-lo para o campo da Educação Matemática, foi um fator determinante para se trabalhar com os conceitos da metodologia de ensino Sequência FEDATHI. Ela é composta de quatro fases, a lembrar: tomada de posição; maturação e debruçamento; solução; e prova. A pesquisa tratou de verificar se essas quatro fases estavam presentes em todo o MD de Cálculo I produzido para o curso semipresencial de Licenciatura em Matemática do IFCE. O qual foi verificado que nem todas as etapas da Sequência FEDATHI estavam presentes nas aulas do MD de Cálculo I.

Através da discussão dos dados coletados na pesquisa de campo, no capítulo 5, foi averiguado que o material didático da disciplina de Cálculo I precisa passar por uma revisão de design instrucional e conteudista. Justamente, porque a metodologia de ensino Sequência FEDATHI não tinha sido usada, inicialmente, na construção desse material didático e conjunto do Design Instrucional Contextualizado.

Com base nisso, o fato que foi mais apontado é que, das três áreas que a disciplina de Cálculo I abrange, o conceito de limites precisará passar por uma reconstrução, pois essa parte não está, didaticamente, clara. Isso pode acarretar possíveis incompreensões na aprendizagem de um aluno que entrou, ou entrará, em contato com esse material.

Sendo assim, a presença de uma metodologia de ensino para mediar o conhecimento fornecido em um material didático para ensino a distância, no caso de Cálculo I, ainda não estava adequada à proposta de se ensinar a distância para um aluno que aprende, também, a distância. Portanto, uma das constatações a que esse trabalho chegou foi que a proposta de se utilizar a metodologia de ensino Sequência FEDATHI, como umas das metodologias de base para a construção de um material didático de Matemática para ensino a distância, passa a ser aqui um ideal a ser perseguido.

Assim sendo, imagina-se que trabalhar com uma metodologia de ensino como a Sequência FEDATHI, aliada a todas as características da produção de um material didático da área de Matemática, e fazer uma reconstrução desse recurso, é um dos caminhos que deve ser percorrido futuramente. Outra constatação é que o atual material didático de Cálculo I, que foi e ainda é utilizado pelo curso semipresencial de formação de professores de Matemática do 
IFCE, ainda não está adequado, didaticamente, ao seu público-alvo, pois o material ainda é encarado como um livro didático para ensino presencial.

Isso foi evidenciado quando os professores-tutores ressaltaram a abordagem complexa do conteúdo no material e também sobre qual fundamentação o MD de Cálculo I estava seguindo, de acordo com os livros didáticos analisados no Quadro 2 do capítulo 2.

Ao se deparar com essa constatação, fica evidenciado na pesquisa que o MD de Cálculo I precisa se adequar aos moldes para o ensino a distância, principalmente aos moldes de um material didático de Matemática, no qual deve haver a presença de uma metodologia de ensino, que oriente o aluno a construir o próprio conhecimento e o faça ter uma experiência matemática significativa. Essa metodologia de ensino, nesse caso, é a Sequência FEDATHI, que executa esse papel com excelência. Isso reforça que o material precisa passar por uma reconstrução.

Também ficaram questionamentos sobre as outras disciplinas de Cálculo, que abrangem o conceito de Limites, Derivadas e Integrais em funções de ' $n$ ' variáveis reais, e que foram produzidas para esse mesmo curso. Como estão? Será que eles seguem o mesmo nível de ensino que a disciplina de Cálculo I? O que os professores-tutores e alunos têm a dizer sobre elas? Se a Sequência FEDATHI é uma metodologia de ensino que se adequa à proposta de transposição didática, então ela pode ser utilizada para construir todo o tipo de material didático da área de Matemática?

Para pesquisas futuras, pensa-se em aprofundar e responder esses questionamentos e outros que podem surgir no caminho percorrido nessa investigação. Para que isso ocorra, também se pode, como encaminhamentos futuros, fazer pesquisas sobre o ensino de Cálculo no ensino superior na sua historiografia mundial e sua influência no Brasil.

Assim também se devem fazer estudos das vertentes da Psicologia da Aprendizagem, mais especificamente na corrente teórica cognivista, na qual, possivelmente, essa pesquisa se insere. Por último, seria interessante fazer grupos focais ou entrevistas com os alunos e outros tutores para captar o ponto de vista desses sujeitos sobre o material didático, não somente de Cálculo I, como, também, das outras disciplinas de Cálculo. 


\section{REFERÊNCIAS}

ALVES, Francisco Régis Vieira. Cálculo I. Fortaleza: UAB/IFCE, 2011.

ARSAC, G.; Chevallard, Y.; Martinand, J;-L; Tiberghiem, A. (eds.). La transposition didactique à l'pepreuve. Grenoble: La Pensée Sauvage, 1994.

ASSOCIAÇÃO BRASILEIRA DE EDUCAÇÃO A DISTÂNCIA (ABED). Censo ead.br: relatório analítico da aprendizagem a distância no Brasil 2012. Curitiba: Ibpex, 2013.

Disponível em: http://www.abed.org.br/censoead/censoEAD.BR_2012_pt.pdf. Acesso em: 03 de nov. de 2013.

AZEVEDO, Fernando de. As ciências no Brasil. São Paulo: Melhoramentos, 1955.

BELEI, Renata Aparecida. et al. O uso de entrevista, observação e videogravação em pesquisa qualitativa. Cadernos de Educação, Pelotas, $n^{\circ}$ 30, jan./jun. 2008. Disponível em: http://www.periodicos.ufpel.edu.br/ojs2/index.php/caduc/article/viewFile/1770/1645. Acesso em: 15 de mar. de 2014.

BELISÁRIO, Aluízio. O material didático na educação a distância e a constituição de propostas interativas. In: SILVA, Marcos (Org.). Educação online: teorias, práticas, legislação e formação corporativa. São Paulo: Loyola, 2003. p. 135 - 146.

BERDÁD, Roger. O material didático impresso no ensino a distância. In: PRETI, Oresti (Org). Educação a distância: ressiginifcando práticas. Brasília: Liber Livro Editora, 2005.

BORGES NETO, H; BRANDÃO, J.C; ROCHA, E.M. E o livro didático de matemática, como vai?. In: HOLANDA, Patrícia H.C; LEITINHO, Meirecele Celiope (Org).

Experiências de avaliação curricular: possibilidades teóricos-práticas. Fortaleza: UFC, 2011. p. $82-103$.

; SANTANA, José Rogério. Sequiência fedathi: uma proposta de mediação pedagógica na relação ensino-aprendizagem. In: VASCONCELOS, José Gerardo (Org.). Filosofia, Educação e Realidade. Fortaleza: UFC, 2003, v. 01, p. 272-286.

(Org). et al. Sequência fedathi: uma proposta pedagógica para o ensino de matemática e ciências. Fortaleza: UFC, 2013.

BRAGA, Cristiane Borges. Didatic: um ambiente de produção de conteúdo didático digital para educação a distância. Dissertação (Mestrado Profissional em Computação Aplicada) Universidade Estadual do Ceará. Fortaleza, 2008.

BRASIL. Lei ${ }^{\circ} 191$, de 24 de agosto de 1893. Aprova o regulamento que organiza a Escola Polytechica de São Paulo. Disponível em:

http://www.al.sp.gov.br/repositorio/legislacao/lei/1893/lei-191-24.08.1893.html. Acesso em: 8 de abr. de 2014. 
Decreto $\mathrm{n}^{\circ} 14.343$, de 7 de setembro de 1920. Institui a Universidade do Rio de Janeiro. Disponível em: http://www.sibi.ufrj.br/Projeto/decreto.html. Acesso em: 15 de mar. de 2014.

Lei no 6.283, de 25 de janeiro de 1934. Cria a Universidade de São Paulo e dá outras providências. Disponível em:

http://www.al.sp.gov.br/repositorio/legislacao/decreto/1934/decreto-6283-25.01.1934.html. Acesso em: 10 de abr. de 2014.

Lei $\mathrm{n}^{\circ}$ 452, de 5 de julho de 1937. Organiza a Universidade do Brasil. Disponível em: http://www.planalto.gov.br/CCIVIL_03/LEIS/1930-1949/L0452.htm\#art4. Acesso em: 20 de mar. de 2014.

. Decreto-lei n ${ }^{\circ} 1.190$, de 4 de abril de 1939. Dá organização à Faculdade Nacional de Filosofia. Disponível em: http://www.planalto.gov.br/CCIVIL_03/Decreto-Lei/19371946/Del1190.htm\#art1. Acesso em: 20 de mar. de 2014.

. Lei n ${ }^{\circ} 3.866$, de 25 de janeiro de 1961. Cria a Faculdade de Filosofia, Ciências e Letras da Universidade do Ceará, e dá outras providências. Disponível em: https://www.planalto.gov.br/ccivil_03/leis/1950-1969/13866.htm. Acesso em: 25 de mar. de 2014.

Lei $\mathrm{n}^{\circ}$ 4.759, de 20 de agosto de 1965. Dispõe sobre a denominação e qualificação das Universidades e Escolas Técnicas Federais. Disponível em: http://legis.senado.gov.br/legislacao/ListaTextoIntegral.action?id=90363\&norma=115901. Acesso em: 20 de mar. de 2014.

Ministério da Educação. Projeto político pedagógico do curso de licenciatura em matemática: modalidade de educação a distância. Juazeiro do Norte: IFCE, 2010.

Ministério da Educação. Guia de livros didáticos: PNLD 2012 - Matemática (Ensino Médio). Brasília: Secretaria de Educação Básica, 2011. Disponível em: http://www.fnde.gov.br/programas/livro-didatico/guia-do-livro/item/2988-guia-pnld-2012ensino-m\%C3\%A9dio. Acesso em: 15 de fev. de 2013.

Ministério da Educação. Referenciais de qualidade para educação superior a distância. Brasília: Secretaria de Educação a Distância, 2007. Disponível em: http://portal.mec.gov.br/seed/arquivos/pdf/legislacao/refead1.pdf. Acesso em: 28 de out. de 2013.

CASTRO, F. M. O. A matemática no Brasil. In: AZEVEDO, Fernando de. As ciências no Brasil. São Paulo: Melhoramentos, 1955.

CHEVALLARD, Yves. Les processos de transposition didactique et leur théorrisation. Em: Arsac G., Chevallard Y., Martinand J.-L, Tiberghiem A. (eds.). 1994. p. 135-180. Disponível em: http://yves.chevallard.free.fr/spip/spip/IMG/pdf/Les_processus_de_transposition.pdf. Acesso em: 28 de fev. de 2014. 
; BOSH, Mariana; GASCÓN, Josep. Estudar matemáticas: o elo perdido entre o ensino e a aprendizagem. Tradução Daisy Vaz de Moraes. Porto Alegre: Artmed. 2001.

CHURCHES, Andrew. Bloom's digital taxonomy. 2009. Disponível em:

http://edorigami.wikispaces.com/file/view/bloom\%27s\%20Digital\%20taxonomy\%20v3.01.pd f/65720266/bloom\%27s\%20Digital\%20taxonomy\%20v3.01.pdf. Acesso em: 28 de abr. 2014.

CORRÊA, Juliane (Org). Educação a distância: orientações metodológicas. Porto Alegre: Artmed, 2007.

CORRÊA, Juliane. Estruturação de programas em ead. In: CORRÊA, Juliane (Org).

Educação a distância: orientações metodológicas. Porto Alegre: Artmed, 2007.

D’AMORE, Bruno. Elementos de didática da matemática. Tradução Maria Cristina

Bonomi. São Paulo: Livraria da Física, 2007.

FILATRO, Andrea. Design instrucional contextualizado: educação e tecnologia. São Paulo: Senac São Paulo, 2003.

Design instrucional na prática. São Paulo: Pearson Education do Brasil, 2008.

FORMIGA, M; LITTO, F.M. Educação a distância: o estado da arte. São Paulo: Pearson Education do Brasil, 2009.

FRANCO, Marco Antonio Melo. Elaboração de material impresso: conceitos e propostas. In: CORRÊA, Juliane (Org). Educação a distância: orientações metodológicas. Porto Alegre: Artmed, 2007.

GUEDES, Jane de Fontes. Produção de material didático para ead no curso de licenciatura em matemática: o caso da UAB/IFCE. 2011. Dissertação (Mestrado Acadêmico em Educação) - Universidade Federal do Ceará. Fortaleza.

GUIDORRIZI, Hamilton Luiz. Um curso de Cálculo. São Paulo: editora LTC, 1986. v.1.

HOLANDA, Patrícia H.C; LEITINHO, Meirecele Celiope (Orgs). Experiências de avaliação curricular: possibilidades teóricos-práticas. Fortaleza: UFC, 2011.

HOUSSAYE, Jean. Le Triangle Pédagogique. Théorie et Pratique de l'Education Scolaire (Vol. 1). Berne: Peter Lang, 1988. Disponível em: http://shs-app.univ-

rouen.fr/civiic/archives/LE\%20TRIANGLE\%20PEDAGOGIQUE.pdf. Acesso em: 28 de fev. de 2014.

JOYE, Cassandra Ribeiro. et al. Capacitação docente para a realização do design instrucional dos materiais didáticos do ensino de graduação presencial no contexto do projeto tics. In:

Encontro de Pesquisa Educacional do Norte e Nordeste - EPENN, 20, 2011, Manaus: UFAM, 2011.

et al. Conteúdo didático online de matemática: o papel do designer instrucional na utilização de recursos web - relato de experiência. In: Congresso Norte Nordeste de Pesquisa e Inovação - CONNEPI, 8, 2013, Salvador: IFBA, 2013. 
Didáticas e metodologias do ensino médio e da educação profissional. Fortaleza: SETEC/IFCE, 2013.

LACROIX, Sylvestre François. Traité Elémentaire de Calcul Différentiel et de Calcul Intégral. Paris: Polytechnique, 1867. Disponível em:

http://gallica.bnf.fr/ark:/12148/bpt6k6292302n. Acesso em: 28 de fev. de 2014.

LEITHOLD, Louis. O cálculo com geometria analítica. Tradução Cyro de Carvalho Patarra. São Paulo: Harbra, 1994. v. 1.

LIMA, Gabriel Loureiro. A disciplina de cálculo I do curso de matemática da universidade de São Paulo: um estudo de seu desenvolvimento, de 1934 a 1994. 2012. Tese (Doutorado Acadêmico em Educação Matemática) - Universidade Católica de São Paulo. São Paulo.

LUFT, Astor E. SCHEER, Sérgio. VERZENHASSI, Camila C. Um repositório aberto e cooperativo de objetos educacionais para engenharia de estruturas. In: Proceedings of the XXVI Iberian Latin-American Congress on Computational Methods in Engineering CILAMCE 2005. Brazilian Assoc. for Comp. Mechanics (ABMEC) \& Latin American Assoc. of Comp. Methods in Engineering (AMC). Espírito Santo, Brasil. Disponível em: http://www.cesec.ufpr.br/etools/oe3/artigos/CIL0088.pdf. Acesso em: $11 \mathrm{de} \mathrm{fev.} \mathrm{de} 2013$.

MOORE, Michael G; KEARSLEY, Greg. Educação a distância: uma visão integrada. Tradução de Roberto Galman. São Paulo: Cengage Learning, 2007.

MACHADO JUNIOR, F. S. Interatividade e interface em um ambiente virtual de aprendizagem. Passo Fundo: IMED, 2008.

MEDEIROS, João Bosco. Redação científica: a prática de fichamentos, resumos, resenhas. 11. ed. São Paulo: Atlas, 2013.

MOREIRA, Maria da Graça. A composição e o funcionamento da equipe de produção. In: FORMIGA, M. LITTO, F. M. Educação a distância: o estado da arte. São Paulo: Pearson Education do Brasil, 2009. p. 370-378.

MOREIRA, Marília Maia. Uso de softwares educativos no estudo da geometria espacial: estudo de caso. Monografia de conclusão de curso. Instituto Federal de Educação, Ciência e Tecnologia - IFCE, 2009.

; ROCHA, Elizabeth Matos. O uso do software elica no ensino de geometria espacial: relato de experiência. In: $\mathbf{2 2}^{\circ}$ Simpósio Brasileiro de Informática na Educação (SBIE) e $17^{\circ}$ Workshop de Informática na Escola (WIE), 2011, Aracajú. Anais do... Simpósio Brasileiro de Informática na Educação, 2011.

Avaliação dos materiais didáticos na perspectiva do aluno: o caso da licenciatura em matemática a distância do IFCE. Monografia de especialização em Ensino de Matemática, Universidade Estadual do Ceará, 2012. 
; PINHEIRO, Ana Cláudia Mendonça. Possibilidades de uso de softwares educativos no ensino de geometria espacial. In: Encontro Nacional de Educação Matemática, 2013, Curitiba. Educação Matemática: Retrospectivas e Perspectivas. Brasília: SBEM, 2013.

OLIVEIRA, Antônio Sylvio Vieira de. O Ensino do Cálculo Diferencial e Integral na Escola Politécnica de São Paulo, no ano de 1904: uma análise documental. 2004. Dissertação (Mestrado em Educação Matemática) - Universidade Estadual Paulista, Rio Claro.

SAVIANI, Demerval. História das ideias pedagógicas no Brasil. Campinas: Autores Associados, 2010.

SILVA, Marcos (Org.). Educação online: teorias, práticas, legislação e formação corporativa. São Paulo: Loyola, 2003.

STEWART, James. Cálculo. Tradução Antonio Carlos Moretti e Antonio Carlos Gilli Martins. São Paulo: Pioneira Thomson Learning, 2006.

SONNET, Hyppolite. Premiers Éléments du Calcul Infinitesimal. Paris: Boulevard SaintGermain, 1884. Disponível em: http://gallica.bnf.fr/ark:/12148/bpt6k91919z. Acesso em: 30 de mar. de 2014.

SOUZA, Maria José de Araújo. Sequência fedathi: apresentação e caracterização. In:

BORGES NETO, Hermínio (Org). et al. Sequência fedathi: uma proposta pedagógica para o ensino de matemática e ciências. Fortaleza: UFC, 2013.

VASCONCELOS, José Gerardo (Org.). Filosofia, Educação e Realidade. Fortaleza: UFC, 2003.

ZICCARDI, L. R. N. O curso de matemática da pontifícia universidade católica de São Paulo: uma história de sua construção/desenvolvimento/legitimação. Tese (Doutorado em Educação Matemática), Pontifícia Universidade Católica de São Paulo, São Paulo, 2009. 
APÊNDICES 


\section{A P Ê N D I C E I - ROTEIRO PARA A ENTREVISTA SOBRE O MATERIAL DIDÁTICO DE CÁLCULO I}

Identificação

Nome:

Sexo

- ( ) Masculino

- ( ) Feminino

Informar faixa etária:

Há quanto tempo você ensina no ensino superior?

Formação

- Graduação em (Licenciado e/ou Bacharel)

- Especialização em

- Mestrado em

- Doutorado em

Você já atuou como tutor em quais polos?

- ( ) Acaraú

- ( ) Camocim

- ( ) Campos Sales

- ( ) Itapipoca

- ( ) Jaguaribe

- ( ) Limoeiro do Norte
- ( ) Meruoca

- ( ) Orós

- ( ) Quixeramobim

- ( ) São Gonçalo do Amarante

- ( ) Tauá

- ( ) Ubajara

Você já atuou quantas vezes como tutor da disciplina de Cálculo I?

- ( ) 1

- ( ) 2

- ( ) 3

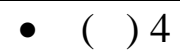

- ( ) 5

Questões sobre o Material Didático (MD) de Cálculo I

1 - O MD de Cálculo I abrange todo o conteúdo de limites, derivadas e integrais em uma única variável. Onde esse material didático consegue facilitar o ensino desses conceitos através de uma abordagem didática dos conteúdos explorados?

2 - Onde e como você percebe que o MD de Cálculo I estimula o aluno nas discussões sobre certo conceito matemático estudado e explorado, com o intuito de propor ao estudante o desenvolvimento de argumentações sobre o raciocínio?

3 - Em quais aulas no MD de Cálculo I se propõe ao aluno que faça uma sistematização dos conceitos aprendidos e induz o aluno a debater e discutir entre os seus pares?

4 - Em quais aulas você percebe o MD de Cálculo I sistematiza e formaliza de maneira adequada os conceitos ou problemas apresentados?

5 - Como e onde você percebe que o MD de Cálculo I consegue transformar os saberes científicos ensinados em saberes aprendidos? 


\section{A P Ê N D I C E I I - TRANSCRIÇÃO DA ENTREVISTA COM O PROFESSOR- TUTOR 1}

Pesquisadora: Bem, pra início de conversa, era pra ser um grupo focal, né?

Professor-Tutor 1: Pras pessoas discutirem, né?

Pesquisadora: Exatamente. A gente discutir sobre isso, é, sobre... O que vocês sentiram do material didático, pra ver o que poderia melhorar, né? $\mathrm{Na}$ parte de limites, derivadas, integrais, que eu sei que é... Essa parte específica é densa, né, e cheia de detalhes, mas como vocês tiveram contato e... Eu acho que o seu tá recente, você foi dessa turma de agora? Ou foi da turma...

Professor-Tutor 1: Não, foi essa que tá terminando ainda. Teve problema no Moodle...

Pesquisadora: Exatamente. Então, só vocês pra dizer assim: “Olha, isso aqui não tá legal, essa tem parte aqui tem que não tá bacana, que poderia melhorar."

Professor-Tutor 1: É, bom, na verdade, eu posso ser sincera e te dizer que eu não usei esse material. Eu só usei... Usei outros livros.

Pesquisadora: Mas usou alguma parte dele?

Professor-Tutor 1: (Deve ter uma negativa com a cabeça nesse silêncio da resposta)

Pesquisadora: Nada?

Professor-Tutor 1: Muita coisa não. Do jeito que tá lá, assim... Eu tive que olhar porque eu tive que olhar as atividades.

Pesquisadora: Mas já é alguma coisa. As atividades, né? Pelo menos, você olhou alguma coisa.

Professor-Tutor 1: Porque a gente tem que saber o que eles vão fazer. É.

Pesquisadora: Né? É... Deixa-me ver a... Seguir aqui as perguntas. Né? Sobre, as questões sobre o material didático de cálculo I, né, objetivo. Primeiro, é... Pra atender a pesquisa acadêmica que eu tô fazendo no mestrado em educação e, futuramente, né, por segundo, seria é... Melhorar o material didático porque essa é uma segunda versão, já, né? Teve uma primeira...

Professor-Tutor 1: Ah, é porque eu não peguei a primeira, não cheguei a ver a primeira.

Pesquisadora: E agora essa é a segunda versão e, futuramente, na terceira, a gente quer melhorar ainda pra vocês, professores tutores, ter mais segurança na hora de utilizar e os alunos também, na hora de utilizar, dizer: "Não, agora eu tô podendo... Vou, né, não é o único livro que eu vou utilizar, mas esse aqui pode ser base, pra outros”, né?

Pesquisadora: Então, aqui, a primeira pergunta... 


\section{DESTE PONTO EM DIANTE A ENTREVISTA SEGUIU FORMALMENTE COM PERGUNTAS DIRECIONADAS SEGUNDO O ROTEIRO}

Pesquisadora: “1 - O MD de Cálculo I abrange todo o conteúdo de limites, derivadas e integrais em uma única variável. Onde esse material didático consegue facilitar o ensino desses conceitos através de uma abordagem didática dos conteúdos explorados?".

Pesquisadora: Onde é que você sentiu assim?

Professor-Tutor 1: É porque assim.. Os alunos, em si, eles também olham, né, não conseguem entender muito porque ele tá muito reduzido. Então, isso acaba levando a gente pra outros livros pra poder abordar de outra forma, detalhadamente, até porque eles têm um déficit de matemática do ensino médio muito grande.

Pesquisadora: Muito.

Professor-Tutor 1: Parece que eles não viram Matemática Básica I e quando a gente chega lá, já... Eles dizem que é rápido.

Pesquisadora: É, mas eles têm até uma disciplina, né? Já de Matemática Básica.

Professor-Tutor 1: Pois não é por isso que a gente já chega lá com todo o gás, aí quando eles "Professora, mais devagar porque assim não tô entendendo nada". Aí, a gente tem que voltar.

Pesquisadora: Mas, das atividades que você disse que viu, mais da parte de atividades, é... Em quais das três áreas você sentiu que ele, que ele abordava melhor? Que introduzia os conceitos melhor? Foi a parte de limite, de derivada ou de integral?

Professor-Tutor 1: Eu acho que é mais a de integral. Até porque a de integral se torna um pouquinho mais fácil pra eles depois, né?

Pesquisadora: Hunrum. Mas aonde, específico, assim, você tem um...

Professor-Tutor 1: Específico, assim, ... que eu vá te mostrar exatamente? Onde é que tá integral aqui? Me ajuda... Agora tem muito exemplo que ele colocou, que foi o "Teorema de Bouzano"...

Pesquisadora: Integral vai estar... A partir da aula 8. Aula 8, 9 e 10. Que vai ser integração, técnicas de integração e aplicações da integral definida.

Professor-Tutor 1: Porque, normalmente, técnicas de integração é quase um semestre, né?

Pesquisadora: Né? E... É abordado aqui...

Professor-Tutor 1: Bem rápido.

Pesquisadora: Na página... Na página 157. 
Professor-Tutor 1: Derivadas também tá... O problema mais é na parte de limite, que teria que tá um pouquinho... Porque, se eles não entenderem o que é limite, aí depois complica bastante.

Pesquisadora: Complica, né? Você sentiu isso? Que limite não tá claro? A parte de limite não, não se aborda como deveria?

Professor-Tutor 1: Eu não sei como é que vocês poderiam fazer pra essa apostila ficar melhor, eu não sei... Porque assim, com a apostila em mãos, ele mal olha o ambiente, né? Você percebe que ele só acessa porque tem que acessar.

Pesquisadora: Pra colocar as atividades...

Professor-Tutor 1: Pra colocar as atividades e pra não ficar com falta, né? Porque parece que... Pesquisadora: Hunrum.

(Silêncio)

Professor-Tutor 1: Por esse aqui, não tá muito legal. Até que eu uso pouco.

Pesquisadora: O que é que não tá legal?

Professor-Tutor 1: A parte aqui do estudo comportamento gráfico mediante o auxílio das derivadas.

Pesquisadora: Mas, não tá legal por quê?

Professor-Tutor 1: Tá muito... Reduzido.

Pesquisadora: Reduzido, né?

Professor-Tutor 1: É. Na verdade, essas apostilas deviam ser logo do tamanho do livro de Cálculo, mesmo, pra poder eles...

Pesquisadora: Estilo qual? Leithold... Guidorizzi?

Professor-Tutor 1: Leithold e o Guidorizzi, não o Guidorizzi eu num gosto muito do Guidorizzi, não. Eu gosto do, esse agora, o...

Pesquisadora: Stewart?

Professor-Tutor 1: Stewart! É. Porque tem umas definições que ele traz diferente do Leithold, né, que a gente nem...

Pesquisadora: Hunrum.

Professor-Tutor 1: Umas interpretações que não tem no Leithold.

Pesquisadora: E eles costumam ser bem, bem grosso, né? Assim, o volume?

Professor-Tutor 1: Porque senão, não sei como é que assiste... Eles chegam ao final do curso, mas eu acho que é básico ele terem domínio do cálculo. 
Pesquisadora: Hunrum. Certeza. Então, mas você acha que na parte de, de integrais eles... Se aborda melhor do que de limites, é isso?

Professor-Tutor 1: É. Num sei se é por que...

(Confusão de vozes. Não entendi. Mas como a professora retoma, a seguir, acho que segue o contexto)

Professor-Tutor 1: É. Aplicações da integral definida. Aqui pra eles, eles não conseguem devolver pra gente uma aplicação. Eles colocam só colocando teoria, teoria, teoria. Na prática, eles não sabem ver uma aplicação das integrais.

Pesquisadora: Os alunos?

Professor-Tutor 1: É.

Pesquisadora: Aí, o livro, ele não consegue... Colocar isso é?

Professor-Tutor 1: Essa parte aqui também não.

Pesquisadora: Qual parte?

Professor-Tutor 1: Ele só tem uma aplicação, principalmente, né não, ó: comprimento do arco... O ideal é que ele jogasse assim, por exemplo, "serve pra isso, serve pra aquilo...", não só mostrar, por exemplo, aqui ele colocou só comprimento do arco. Então, ficou um pouco vago.

Pesquisadora: Hunrum. Então seria uma aplicação, assim, tipo, na Física, né, que tem aplicação. Que você sentiu isso foi, que não teve..

Professor-Tutor 1: É. Teve. E eles ficam desnorteados, assim: "Cadê a aplicação em si?", entendeu? Só, no máximo, pra calcular aquele negócio lá da caixa d’água, que...

Pesquisadora: Tem teoria matemática... Não seria uma aplicação mesmo, na geometria, né, que tem partes, se não me engano e não, se não me falha a memória, na parte assim de geometria, né, que ele pega mesmo a geometria sólida e coloca integrais lá, né? Se não me engano.

Professor-Tutor 1: É.

Pesquisadora: Aí, tem a Física e tem a Química. É isso? Sentiu falta disso.

Professor-Tutor 1: Por exemplo.. É. Ele dizer nem que seja, é... Ele diga, nem que seja assim: "Não, eu vou usar", vamos supor, hipoteticamente, "Eu vou usar a integral pra calcular alguma coisa daquele prédio que ele tá construindo", vamos supor que seja. Ele tem que saber que a integral tá por ali, porque o que a gente muita escuta é: “Ah, não vou usar, não tem prática, não tem aplicação". Pode não ter direta, mas tá, indiretamente, tá em um bocado de coisa. 
Pesquisadora: É, e no caso da, de cálculo é só o que tem, né?

Professor-Tutor 1: Só o que tem, mas ele não consegue ver, assim..

Pesquisadora: Hunrum.

Professor-Tutor 1: Tão claro.

Pesquisadora: Eu sei. É... A segunda pergunta, aqui:

Pesquisadora: "2 - Onde e como você percebe que o MD de Cálculo I estimula o aluno nas discussões sobre certo conceito matemático estudado e explorado, com o intuito de propor ao estudante o desenvolvimento de argumentações sobre o raciocínio?"

(Silêncio)

Pesquisadora: Né? Onde, assim, que você percebeu que ele chama o aluno pra discutir o conceito?

Professor-Tutor 1: É, eu tenho que, teria que tá no material, né? Tivesse me dito antes, eu tinha olhado bem direitinho. Mas eu achei legal na hora que eles constroem, em integral, a, o conceito de ser inverso da derivada. Agora, onde está aqui... É bem no comecinho, né, que ele vai... Acho que é no anti-derivada...

Pesquisadora: É mudança de variável, integração por partes, primitiva, integral?

Professor-Tutor 1: Não, não. É bem pelo comecinho da... É, negócio das primitivas, 157. É porque aqui é bem, muito resumido, demais, mas é na primitiva de uma função, na hora que eles...

Pesquisadora: Na hora?!

Professor-Tutor 1: Na hora que eles percebem o processo que você tem que voltar e vai descobrir... É porque assim, eu não sei te explicar das anti-derivadas, da família, das coleções, aquele porquê que.. Ave Maria porque assim, pra mim explicar pra ti é mais difícil. Porque que tem aquele "num sei o que" mais o "c". Porque na hora de derivar, aquela constante lá...

Pesquisadora: É... integral primitiva.

Professor-Tutor 1: É. Aí, que na hora você vai mostrar, que, por exemplo, a função " $3 \mathrm{x}^{2}+5$ ", aí, porque que isso aqui é o tal do "+c".

Pesquisadora: Hunrum. Quando ele faz a volta, né? Quando ele faz o processo de, de retorno à derivada.

Professor-Tutor 1: É quando ele faz a volta. Porque ele consegue ver aquela coleção de funções que podem ser...

Pesquisadora: Hunrum.

Professor-Tutor 1: Mais por aqui, só que também tá... 
Pesquisadora: Tá precisando de uma atenção a mais, né? De uma melhorada.

Professor-Tutor 1: É, porque tem polo que ele só tem isso aqui, né? Só tem isso aqui e a internet. Itapipoca tem uma biblioteca muito boa, mas não são todos.

Pesquisadora: Ubajara também, né? Ubajara?

Professor-Tutor 1: Não fui pra Ubajara. Só fui pra lá...

Pesquisadora: Nunca foi? Lá também eles têm uma (...).

Professor-Tutor 1: ...e Camocim. Camocim eles já são muito soltos.

Pesquisadora: Soltos, como assim?

Professor-Tutor 1: Assim, é só eles por eles. Não tem essa estrutura física, como a de Itapipoca.

Pesquisadora: Hum... Não sei se eu vi, se eu fui alguma vez pra Camocim. Itapipoca eu nunca fui. Fui de Ubajara. Ubajara, eles têm uma biblioteca.

Professor-Tutor 1: Tem? É muito boa a deles, assim, né? Tanto quanto a da UFC, digamos assim, né?

Pesquisadora: Hunrum. É... Então a terceira pergunta...

Professor-Tutor 1: Tu ia querer isso aqui, num ia? Acabei de riscar.

Pesquisadora: Hum?

Professor-Tutor 1: Tu ia querer esse papel, num (..)?

Pesquisadora: A terceira pergunta:

Pesquisadora: “3 - Em quais aulas no MD de Cálculo I se propõe ao aluno que faça uma sistematização dos conceitos aprendidos e induz o aluno a debater e discutir entre os seus pares?"

Professor-Tutor 1: Acho que em todas, né?

Pesquisadora: Em todas?

Professor-Tutor 1: Todas ele faz isso, embora o aluno, às vezes, não faça...

Pesquisadora: Tá. E...

Pesquisadora: "4 - Em quais aulas você percebe o MD de Cálculo I sistematiza e formaliza de maneira adequada os conceitos ou problemas apresentados?"

Professor-Tutor 1: Isso ele faz, problema é que está muito resumido, muito... pequeno.

Pesquisadora: Muito pequeno...

Professor-Tutor 1: É, muito pequeno. Teria que ter uma exploração maior...

Pesquisadora: Dos conceitos...

Professor-Tutor 1: É. Maior, mais exemplos, se pudesse. 
Pesquisadora: Mais exemplos... Mas o conceito em si, assim, não sei se você chegou a ver.

Professor-Tutor 1: Não, o conceito é quase como se a gente tivesse num mestrado... É um pouquinho mais... tipo, o Guidorizzi, ele é muito conciso, ele é muito pouco. Se você, quem pega cálculo pela primeira vez, sente dificuldade.

Pesquisadora: Eu sei. É, o Guidorizzi eu já senti também. Ele, tu acha que ele segue o estilo do Guidorizzi?

Professor-Tutor 1: É.

Pesquisadora: Mais do que o Leithold?

Professor-Tutor 1: Mais ou menos.

Pesquisadora: Porque o Leithold é bem simbólico, né? Tem toda aquela simbologia, ele explora bem essa simbologia.

Professor-Tutor 1: É, é. Praticamente, é como se você tivesse vendo a análise no Leithold, né? Pesquisadora: Isso, exatamente. E Stewart, se eu não me engano, é... Assim, pelo pouco que eu utilizei o Stewart, ele, ele tem a aplicação e tem a teoria. Então, ele tenta 'conversar' com os dois.

Professor-Tutor 1: É, é. Ele é 'moderno', digamos assim. Também, o Leithold é de quando, ein?

Pesquisadora: E, se eu não me engano, ele é um pouquinho mais avançado do que os outros, né?

Professor-Tutor 1: É, mas aí tem coisas..

Pesquisadora: (...) aí tem que descer, tem que saber um pouquinho de cálculo.

Professor-Tutor 1: Eu acho que aquele negócio lá do, negócio do, a integral, tipo, seno de.. como é limite trigonométrico fundamental, eu acho que eu não achei nele, não.

Pesquisadora: No...

Professor-Tutor 1: Stewart! Acho que num tá não.

Pesquisadora: Tu acha que esse, esse livro aqui, o material didático de cálculo I, ele segue mais o estilo do Guidorizzi, né?

Professor-Tutor 1: É.

Pesquisadora: Que é mais conciso, mais direto, objetivo.

Professor-Tutor 1: É, como se fosse um curso mais avançado.

Pesquisadora: Hunrum.

Professor-Tutor 1: E pra eles, quanto mais esmiuçado for, é melhor.

Pesquisadora: Ainda mais pra quem tá (...) pela primeira vez. 
Professor-Tutor 1: É, e ainda mais que a gente atrasa e, eu num sei assim, no geral, se todos têm esse déficit, né?

Pesquisadora: É, depende de polo pra polo.

Professor-Tutor 1: Depende de...

Pesquisadora: Né, de público alvo, assim.

Professor-Tutor 1: Que a gente chega lá já no estilo Guidorizzi também, aí eles dizem: “Ah, meu Deus..."

Pesquisadora: Tá certo.

Professor-Tutor 1: “... volte mais um pouco”.

Pesquisadora: Então, ah... Mais alguma coisa pra falar sobre isso? Não?

Professor-Tutor 1: Não, só uma parte, não sei se tem aqui ou se é no da professora.. É porque vocês falam muito da gente, eles falam muito da gente evitar o plágio e, nas apostilas, tá tal, por exemplo, pegar um... Uma atividade do Stewart, do jeito que tá lá, e jogar sem nem dizer que a fonte é de lá...

Pesquisadora: Hunrum.

Professor-Tutor 1: ...É meio complicado.

Pesquisadora: Sem nem citar, assim, dizer que é de lá.

Professor-Tutor 1: Sem nem citar, ainda dizer que é elaborado por você, diga assim, pelo menos, que foi organizado...

Pesquisadora: Que foi tirado de lá, é.. "Exercício extraído do ... do livro Stewart”, é isso?

Professor-Tutor 1: É.

Pesquisadora: Pronto. Tá. É... Certo. Aí, o 5º então:

Pesquisadora: “5 - Como e onde você percebe que o MD de Cálculo I consegue transformar os saberes científicos ensinados em saberes aprendidos?"

Pesquisadora: Né? Quando você acha, assim, que o material didático conseguiu, em alguma das partes, não em todas, né? Eu sei que, como você falou, em limites, ele... Não explora como deveria ser explorado, mas... Em qual, em quais das partes: limites derivadas ou integrais,e aí você percebe que, pelo menos, ele tentou, assim, fazer com que aqueles saberes científicos, né, de integral, limites, derivadas, é.. Foi, é... O autor conseguiu, é... Transmitir é... Esses saberes científicos para os saberes ensinados pros alunos.

Professor-Tutor 1: Como a gente percebe? Através da prova, né? Seria isso? Porque a gente, pelas atividades em si... 
Pesquisadora: Mas, não, mas é tipo assim em qual, em qual das áreas aqui abordadas, no livro? Você percebe, assim, que...

Professor-Tutor 1: ... Que ele consegue transformas os saberes científicos ensinados em saberes aprendidos.

Pesquisadora: Seria a prova mesmo, que você falou, assim, que na prova...

Professor-Tutor 1: É porque na prova a gente sabe se ele realmente aprendeu alguma coisa, agora, saber se foi do material didático, aí já é...

Pesquisadora: Mais complicado...

Professor-Tutor 1: Mais complicado.

Pesquisadora: Entendo. No geral, assim, o que é que você, como é que você avalia o material didático? Dessa disciplina. Porque essa tua opinião vai ser importante pra depois, é... Quando vir uma reformulação do material didático, né? Eu.. Como eu vou ter que... Como eu sou a Designer Educacional que acompanha o material, e eu tenho formação em matemática, então a coisa é também só eu ter...

Professor-Tutor 1: Ajuda, né? É bom que alguém da área ajude.

Pesquisadora: E outra coisa é o que os tutores tão falando, né? Aí eu vou perceber, assim, mais ou menos, onde é que eu tenho que melhorar, falar com o professor: "Professor, olha você tem que melhorar aqui. Então, bora ter uma conversa né?” Pra...

Professor-Tutor 1: Pra que, eu acho assim, pra que eles tenham, pelo menos, um.. Uma vontade de explorar, o ambiente, alguma coisa que tivesse só lá, e não tivesse aqui, como extra, né? Seria bom também.

Pesquisadora: Mas tem. Tem lá o material didático de... Online, né? Só que, eu acho que acaba sendo a reprodução.

Professor-Tutor 1: É..

Pesquisadora: Do impresso, só que com alguns recursos visuais.

Professor-Tutor 1: E alguma.. Outra coisa do chat, vocês num tão pensando em colocar aquela linguagem matemática pra que a gente digite melhor, não? Porque, ô coisa ruim é a gente conversar com eles...

Pesquisadora: Eu sei. Eu acho que isso tá sendo estudado, né? Aqui a gente tá tentando melhorar o ambiente..

Professor-Tutor 1: Colocar aquele, como é o nome daquele bichinho que a gente escreve as fórmulas? É o...

Pesquisadora: É o... Mathtype, não sei. O... Também aquele... Latex. 


\section{Professor-Tutor 1: É!}

Pesquisadora: É, é uma opção. Parece que... Eu acho que tentei colocar uma vez lá Latéx, Latex, eu não sei nem como é a pronúncia direito, mas parece que ele deu conflito com alguma parte do sistema do Moodle.

Professor-Tutor 1: E o que foi que aconteceu com o Moodle, que ele tá tal qual aquele do Stewart? Tu viu que o Stewart, ele tem um ambiente também igual esse que tá agora do Moodle, né?

Pesquisadora: Stewart?

Professor-Tutor 1: É. A, a 'editora Cengage Learning', alguma coisas... E o Moodle, agora que pegaram essa versão, agora tá igual a de lá.

Pesquisadora: Tá? Não sei. Não sei qual é a de lá, não.

Professor-Tutor 1: Tá. Tem algumas coisas até que tá em inglês, igual tá lá. Parece que pegaram, traduziram.

Pesquisadora: Tu tá falando do Stewart, o que? Da.. do livro?

Professor-Tutor 1: Daquele livro de Cálculo. É.

Pesquisadora: E eles têm uma... um Moodle?

Professor-Tutor 1: Ele tem um ambiente virtual, também, um.. um ambiente virtual de aprendizagem.

Pesquisadora: Não sabia.

Professor-Tutor 1: Aí, eu me inscrevi lá, mas só que só podia por um semestre, eu acho que já passou.

Pesquisadora: Ah, tá.

Professor-Tutor 1: Mas era igualzinho a esse Moodle novo.

Pesquisadora: Bem, assim, teve problemas com os LVs, né? Eu acho que a equipe técnica, se não me engano, tá tentando resolver essa parte aí dos LVs, né? Então, é... Fora isso, eu não sei te dar mais informações porque é uma parte bem técnica, aí já não é da minha alçada, já não é da minha área.

Professor-Tutor 1: Eu acho que o material precisa melhorar. Eles precisam ver que os alunos estudam praticamente sós, né? Então...

Pesquisadora: Certeza, né, colocar o que? Uns exercícios colocados mais passo a passo, aumentar o volume...

Professor-Tutor 1: É, com certeza. 
Pesquisadora: ... Porque, eu acho, que com uma variável, como você colocou aqui, né, esse aqui ainda tá fininho pelo...

Professor-Tutor 1: É. Já que é pra investir na... Tem que investir também na qualidade, né? Então, já que vai dar o material pra eles, que dê logo um tipo o Lethold mesmo.

Pesquisadora: Leithold ou...

Professor-Tutor 1: Tipo, é..

Pesquisadora: Stewart.

Professor-Tutor 1: É. Tipo, Guidorizzi num rola não porque você olha até que os bichinhos são...

Pesquisadora: É, o Guidorizzi é bem conciso, mesmo, bem resumido. Bem, é isso. É, professor, assim, é... Não se preocupe que o seu nome não vai ser falado, viu? Eu lhe asseguro isso...

Professor-Tutor 1: É. Eu nem sei nem quem o não sei nem quem o professor conteudista.

Pesquisadora: É, mas eu lhe asseguro que o seu nome não vai ser... É... mencionado na pesquisa. Sempre vai ser a, a professora "a", a professora " $x$ "... A gente não pode mencionar nomes, certo? Isso eu lhe asseguro, não se preocupe que você deve tá pensando assim: “Ah, vai falar meu nome, aí depois... Vão procurar aí não vou me chamar para ser tutora...”, não. Eu lhe asseguro, como pesquisadora, que eu não vou mencionar seu nome na... Na pesquisa e vai ficar mesmo só pra... Pra essa parte de coletar, é... Dados, né, sobre como é que se encontra o material didático, né, pra ver se ele atende a esses quesitos que foram colocados aqui e outros que você acabou mencionando, que eu nem pensava, né? É porque, como eu te falei, uma coisa é o meu olhar de designer, outra coisa é o olhar do professor conteudista, outra coisa é o seu olhar de professora tutora...

Professor-Tutor 1: De quem tá na ponta com o aluno, né?

Pesquisadora: Com o aluno, e o aluno dizendo: “Ó, professora, as tarefas são isso e não estão de acordo com o livro. E aí?”.

Professor-Tutor 1: É. É o que eles dizem muito.

Pesquisadora: Aí você tem que ter jogo de cintura.

Professor-Tutor 1: Aí, quando a gente usa... Por isso que eu já uso um livro mais avançado do que o material. Aí, quando chega na prova, tá já, mais ou menos, o mesmo nível.

Pesquisadora: Exatamente, é como você me falou.

Professor-Tutor 1: Porque se a gente for usar, realmente, esse aqui, num fica no mesmo nível não. 
Pesquisadora: É, e é até uma, uma coisa que você falou: “Ah, ele... Parece que ele segue mais o estilo do Guidorizzi, bem conciso", né? Onde ele... explora...

Professor-Tutor 1: Seria um material, é, exatamente. Seria um material pra depois, futuramente, ele consultarem só pra alguma dúvida, quando eles tiverem, quem sabe, lecionando, né?

Pesquisadora: É, e o que eu tive de contato dos três, né, Stewart, Guidorizzi e Leithold, eu acho ele muito simbólico, né? Explora essa parte de simbologia, assim, bem muito.

Professor-Tutor 1: É. Tem gente que não gosta, mas aí, eu acho que quem não gosta já tá lá no doutorado, pós-doutorado.

Pesquisadora: Isso. Aí, Stewart, ele explora a parte teórica e aplicação de um jeito bem bacana, apesar de ele também ser bem avançado, né?

Professor-Tutor 1: Mas é bom aquela visão que ele coloca, que o Leithold também não coloca. Ele é um pouquinho mais aplicado também.

Pesquisadora: Isso. E o Guidorizzi, que é o que você falou que tá bem próximo do que o material didático, em si, parece ser né, ele é bem conciso. E, por acaso também, esses três autores é utilizado como referência aqui atrás. Num sei se você já deu uma olhada, assim, como curiosidade, né?

Professor-Tutor 1: Não, eu acho que...

Pesquisadora: Os três são falados, são mencionados, o autor se baseou pelos três.

Professor-Tutor 1: E o Elon também, né, eu acho que ele também tá tipo Elon. O Elon...

Pesquisadora: Mas o Elon não falo nem muito porque eu falo... O Elon, ele já é mais pra mestrado, doutorado.

Professor-Tutor 1: Falou não. É! Pronto! O Elon, quando você vai ler ele assim, até na hora da matemática do ensino médio, quando a gente, depois de formado, vai ler, ele é bem a nível de pós-graduação.

Pesquisadora: Eu citei os três porque são os mais mencionados pelos alunos na minha época de graduação, que o pessoal falava mais: "Não, o Leithold, o Guidorizi... Stewart".

Professor-Tutor 1: Mas não, realmente, o Elon a gente só vê depois que a gente termina (graduação), né, quando vai tentar mestrado.

Pesquisadora: Aí, o Elon já é mais pra quem já sabe cálculo e quer só se aprofundar, né? Então é isso, professor. Assim, desculpa, assim, eu... Eu tinha planejado uma coisa, assim, né? 
Professor-Tutor 1: Ficava legal, se todos, é.. Realmente, ficava bastantes opiniões, seria legal mesmo. Mas acho que é difícil, também, juntar. É igual na estatística, pra fazer uma pesquisa: o pessoal não quer responder...

Pesquisadora: Ah, imagino.

Professor-Tutor 1: É..

Pesquisadora: É bom saber que você é da área de Estatística também, assim... É... Porque eu pensei que ele (coordenação de matemática) só... só selecionavam professores de matemática com graduação na área.

Professor-Tutor 1: Só tinha matemática? Não. É porque tem gente que teve 3, ou 4 disciplinas de cálculo e era junto com o pessoal da matemática. Então, acho que é...

Pesquisadora: Hunrum, mas é bom saber assim também.

Professor-Tutor 1: é a mesma coisa, né, praticamente.

Pesquisadora: Até mesmo pra, quando... Quando a coordenação, assim, saber no caso, assim, é.. Uma pessoa que tenha formação na estatística, né, porque tem também disciplinas de estatística, e saber que você é da área... Né?

Professor-Tutor 1: É, já o de estatística tá um pouquinho melhor, mas mesmo assim a gente já usa outros livros, como Meyer...

Pesquisadora: Pronto. Então, é isso professor. Obrigada.

Professor-Tutor 1: Não, não, que é isso. 


\section{A P Ê N D I C E I I I - TRANSCRIÇÃO DA ENTREVISTA COM O PROFESSOR- TUTOR 2}

Pesquisadora: Tá, aí a gente começa com as perguntas.

Professor-Tutor 2: Com as perguntas aqui, né? Vamos lá.

Pesquisadora: Isso. É, é só pra informar pro senhor que o seu nome não vai ser citado no trabalho, né?

Professor-Tutor 2: Tá, tudo bem, é somente pra ti.

Pesquisadora: Já sabe esse procedimento, né?

Professor-Tutor 2: Não... Sei como é. Somente pra...

Pesquisadora: O senhor sempre vai ser citado como professor "x", professor "a", pra assegurar seu anonimato.

Professor-Tutor 2: Eu posso... Quando eu falar, eu vou falar aqui, mas, em momento algum sai o nome, né? No áudio, você... Começou, aí...

Pesquisadora: Isso, tá.

Professor-Tutor 2: Ah, mas... Aí você vai só transcrever, né?

Pesquisadora: Isso só vai transcrever.

Professor-Tutor 2: Isso aí só vai servir como prova, né?

Pesquisadora: Isso. Aí, assim, é, o senhor aceita, né? A entrevista...

Professor-Tutor 2: Aceito.

Pesquisadora: Pronto. Isso é... São procedimentos básicos, né?

Professor-Tutor 2: Tudo bem.

Pesquisadora: O senhor sabe, né... O senhor foi pesquisador, né, o senhor é pesquisado.

Professor-Tutor 2: É, eu também já fiz, já. Eu fiz um...

Pesquisadora: Aí, a gente tem que... Fazer toda essa trajetória, né?

Professor-Tutor 2: Toda trajetória, exatamente.

Pesquisadora: Exatamente. Aí, assim: é... A pesquisa é sobre o material didático de Cálculo I, né?

Professor-Tutor 2: Certo.

Pesquisadora: Pra saber o... Que é que ele... Quais são as coisas que ele... Que o, que o senhor, assim, como professor tutor, entrou em contato com ele, né? Os alunos também, mas mais o senhor e o... E os outros professores tutores entraram em contato com ele...

Professor-Tutor 2: Certo. 
Pesquisadora: Pra saber o que é que precisa melhorar o que é que... O que é que, qual.. Das três áreas, limites, derivadas e integrais, quais das três áreas é... O autor abordou melhor... Coisas desse tipo, certo?

Professor-Tutor 2: Certo.

Pesquisadora: Aí.. Ã... São cinco perguntas.

Professor-Tutor 2: Pronto. Vamos começar, assim, pela primeira agora?

Pesquisadora: Pela primeira.

Professor-Tutor 2: Vamos lá.

Pesquisadora: Aí, a primeira, assim... Eu vou falar certo? Se o senhor tiver outras questões que estejam relacionadas à pergunta, pode ficar à vontade pra falar.

Professor-Tutor 2: Certo. Tudo bem. Anram.

DESTE PONTO EM DIANTE A ENTREVISTA SEGUIU FORMALMENTE COM PERGUNTAS DIRECIONADAS SEGUNDO O ROTEIRO

Pesquisadora: "1 - O MD de Cálculo I abrange todo o conteúdo de limites, derivadas e integrais em uma única variável. Onde esse material didático consegue facilitar o ensino desses conceitos através de uma abordagem didática dos conteúdos explorados?".

Professor-Tutor 2: É... Pode começar, né?

Pesquisadora: Pode sim.

Professor-Tutor 2: É... Não, eu acho assim, o conteúdo de derivadas e integrais tá bom. Certo? Pesquisadora: Hunrum.

Professor-Tutor 2: Ele consegue, ele tá bem didático, bem... Eu que tenho experiência com o Leithold, por exemplo, que é um livro que ele cita aqui na... Na referência...

Pesquisadora: É...

Professor-Tutor 2: Tá bem as... tá bem as... tá bem.. ele seguiu bem a abordagem do Leithold, certo? Assim, certo...

Pesquisadora: Bem simbólico?

Professor-Tutor 2: Bem simbólico, bem.. Limite e derivada, ele dá a definição, ele dá exemplo, tá entendendo?

Pesquisadora: Anram. Mas ele consegue facilitar, assim, a introdução dos conceitos?

Professor-Tutor 2: Consegue? Limite e derivada. Consegue.

Pesquisadora: Em limite e derivadas, né? 
Professor-Tutor 2: Eu percebo, é... Ele, ele consegue, ele dá a definição gráfica, né? De derivada, ele dá a visão gráfica, começa do gráfico. Aí, mostra o que é o limite, mostra... Ele consegue mostrar.., ele deixa bem claro que a derivada é o coeficiente igual ao da reta tangente, certo? Ele faz bem... Como qualquer outro livro, ele faz bem essa introdução. Ele deixa bem claro para o aluno que é importante o aluno saber que... O que é uma derivada? É o coeficiente angular, né? Da reta tangente no ponto.

Pesquisadora: Anram.

Professor-Tutor 2: Então, quando eu calculo f .. nito de x 0, ali eu tô calculando quem? A equação da reta tangente daquele ponto em uma curva. Ele deixou bem claro isso daí, explica bem direitinho.

Pesquisadora: Isso em limites e derivadas.

Professor-Tutor 2: Pronto. Aliás, não, assim... Derivadas, né?

Pesquisadora: Hum...

Professor-Tutor 2: Quando ele chega em integral, também, ele explica bem, o teorema fundamental do cálculo, o método dos trapézios, ele deixa bem explicado. Ele... O (ideia) do limite. Agora, a parte introdutória de limite é que, eu acho, que devia ser em funções, porque antecede essa parte porque é importante pra essas duas aqui e deixa a desejar, na minha opinião.

Pesquisadora: Sim...

Professor-Tutor 2: Na parte de função, por exemplo, que ele, ele, ele fala, ele abrange basicamente, assim, umas duas funções básicas, né? $1^{\circ}$ grau e $2^{\circ}$ grau... E ele não fala lá que ele num.. Que... Aqui no conteúdo, por exemplo, que a função do segundo grau é ela pode admitir inversa, né? Ele diz que é... é uma coisa que os professores, viu, que... Que se formam muitos professores, erradamente, diz lá pros alunos: "Ah! A função do $2^{\circ}$ grau...", "Professor..."... Porque se você definir a função do segundo grau de R em L, ela num admite inversa mesmo não, porque ela é uma parábola, ela não vai ser injetora, corta logo, 2x... Vai ser simétrico. Aí, o aluno pergunta: "E, professor, quer dizer que a função do $2^{\circ}$ não admite inversa?". Aí, o professor, erradamente..., ele num tem culpa não. Porque, se ele pegar esse livro aqui..., Não fala... E se ele pegar outro livro de matemática, não fala, mas, na verdade, a função, a função do $2^{\circ}$ grau, se você limitar o domínio dela ao x do vértice, certo, e ao y do vértice, ela admite inversa.

Pesquisadora: Hunrum.

Professor-Tutor 2: Tá entendendo? Ou não? 
Pesquisadora: Tô entendendo.

Professor-Tutor 2: Então, você não pode dizer que a função do $2^{\circ}$ grau não admite inversa. Então, é uma falha, é uma falha não só nesse livro, né? É, é... Eu acho que o Leithold, também, é uma falha do Leithold, que é um bom livro, também, e não fala isso aí, esse exemplo, mas eu acho que é interessante, porque como eu vou ser professor...

Pesquisadora: É sim.

Professor-Tutor 2: Né? Então, assim, é... Essa parte do $2^{\circ}$ grau, limite infinito, esse problema aí.. é.. Exponencial, logaritmo... tá entendendo ou não?

Pesquisadora: Tô entendendo.

Professor-Tutor 2: É, essa, essa... Essa função do $2^{\circ}$ grau, uma falha, né, que ele podia ser introduzido aí, tá bom?

Pesquisadora: Anram

Professor-Tutor 2: E também, quando chega em limites, é... Limites 0 sobre 0 , indeterminação..

Pesquisadora: Hunrum...

Professor-Tutor 2: Pronto, então você tem $\mathrm{x}^{2}$, um exemplo bem simples que ele dá aqui e todo livro dá: $x^{2}+1$ sobre $x-1$. Como o limite, o aluno já sabe que o limite não, não tá definido, se eu botar 1 , dá 0 sobre 0 , como vai definir o professor, ele diz que a função não tá definida no ponto, então eu posso cancelar.

Pesquisadora: Anram

Professor-Tutor 2: Como $x^{2}$ é $x+1$ sobre $x-1$, cancela, aí isso aí vai dar uma reta. Aí, vai dar uma reta com um buraco, usando a linguagem vulgar, um pulo, um buraco no 1 .

Pesquisadora: Hunrum

Professor-Tutor 2: Aí a gente explica o limite, o aluno entende: 0/0. Só que ele dá poucos casos. Aí, ele dá produtos notáveis, né, que é o caso corriqueiro, né?

Pesquisadora: Isso, exatamente.

Professor-Tutor 2: Mas o que é que falta? Outra coisa que falta no material aqui... É, por exemplo, se ele... Você tiver dois polinômios... Aí, você aplica o teorema do resto, depois, aplica a forma fatorada, depois aplica Briot-Ruffini. Tá faltando, aqui, exemplo assim.

Pesquisadora: Se eu não me engano, ele faz de uma forma muito tímida isso.

Professor-Tutor 2: Exatamente.

Pesquisadora: Assim, muito rápida. 
Professor-Tutor 2: Pronto, muito rápida. Ele, ele tá faltando exemplo desse tipo... Um polinômio de grau 3 e um polinômio de grau 2.

Pesquisadora: Anram

Professor-Tutor 2: Aí, a teoria dos polinômios que o aluno tem que saber. Ele não fala. Pelo menos, ele botasse no final aqui... Ele podia não colocar aqui, mas no final colocava: BriotRuffini...

Pesquisadora: Como um apêndice.

Professor-Tutor 2: Um apêndice, é. Briot-Ruffini, né, que.. é.. você (...) usar, Teorema do resto..

Pesquisadora: Anram

Professor-Tutor 2: Porque, teorema do resto diz o seguinte: se $\mathrm{p}(\mathrm{a})=0$, x é divisível. Quando ele bota dois polinômios, ele é... Vai, p(a) vai ser 0 , que é o x, né? Aí, aplica o Briot-Ruffini pra baixar o grau. Então, aí, você consegue se livrar do 0/0, entendeu ou não?

Pesquisadora: Tô entendendo.

Professor-Tutor 2: Pronto.

Pesquisadora: Tô entendendo.

Professor-Tutor 2: É uma falha, é.. Eu acho assim, falta só completar limites, tá entendendo?

Pesquisadora: Eu sei.

Professor-Tutor 2: Pronto.

Professor-Tutor 2: Pronto. Bom, é, é... Agora, essa outra parte aqui tá boa, viu? Ele explora bem, ele num deixa a desejar, não, sabe, essa parte de, de derivada e integral.

Pesquisadora: Construções de gráficos...

Professor-Tutor 2: Pronto. É (...) isso e, outra coisa, uma coisa que ele completa dessa parte aqui, sabe porque é que se completa, porque lá no final ele tem uns exercícios, né? Eu gostei do material, porque os outros não têm, que podia ter nos outros.

Pesquisadora: É... O que é? Os exercícios de aprofundamento?

Professor-Tutor 2: E ele faz uma parte só de exercícios. Aí, ele pega com isso aqui, ó. Essa, essa parte aqui de integral e derivada é bem explorado, aqui.

Pesquisadora: Aonde é que é?

Professor-Tutor 2: Tá aqui, ó, exercícios resolvidos, ele fala bem aqui, ó.. No final. Ele tem, ó... Ele tem uma parte...

Pesquisadora: É... Qualquer coisa... 
Professor-Tutor 2: Não, ele, ele tem um... Ele tem uma parte aqui só de exercícios resolvidos, certo? Eu num sei qual é, não, mas tem...

Pesquisadora: Vamos ver no sumário.

Professor-Tutor 2: É... Tem... Exercícios resolvidos. É apêndice "num sei que” dos resolvidos, diz aí...

Pesquisadora: Ã.. Miscelânea dos exercícios resolvidos.

Professor-Tutor 2: Pronto! Isso aí. Miscelânea dos resolvidos, tá aí.

Pesquisadora: Hunrum.

Professor-Tutor 2: Nessa miscelânea, ela taca bem isso aqui... Derivada, para definir integral. Pesquisadora: Que é justamente, é... Na aula de estudo do comportamento gráfico de funções. Professor-Tutor 2: Do comportamento que foi.. Ele vai usar tudo o que ele precisa de limite e derivada. Aí, completa derivada, porque ele vai, ele vai... Esse comportamento aqui é pra ver se a função é crescente... O aluno que estuda Cálculo I, você sabe que ele vai ter condição de esboçar um gráfico de grau 3. Ele não sabe... Aí, nessa miscelânea, ele, exatamente, ele com.. ele dá exemplos bem legais, tá entendendo?

Pesquisadora: Tô entendendo.

Professor-Tutor 2: Aí o aluno aprende.

Pesquisadora: Porque ele vai pegar os conceitos de limites, derivadas aí vai fazer tipo um... Um resumo.

Professor-Tutor 2: Pronto. E ele... Essa miscelânea, com o que tem lá, completa derivada. E integral também é introduzida, essa parte de integral aqui, tá legal.

Pesquisadora: Tá certo.

Professor-Tutor 2: Ok?

Pesquisadora: Ok.

Professor-Tutor 2: Pronto, essa parte aí eu acho que... é isso aí, sabe, que.. né?

Pesquisadora: Anram. Aqui a segunda questão...

Professor-Tutor 2: Pronto

Pesquisadora: "2 - Onde e como você percebe que o MD de Cálculo I estimula o aluno nas discussões sobre certo conceito matemático estudado e explorado, com o intuito de propor ao estudante o desenvolvimento de argumentações sobre o raciocínio?"

Pesquisadora: Né, quando é que o autor chama, assim, o aluno pra pensar, pra raciocinar?

Professor-Tutor 2: Eu acho que ele.. A parte que ele, mesmo, é nessa parte aqui de, de.. comportamentos, né? Essa parte aqui da... aula 7. 
Pesquisadora: Aula 7, né?

Professor-Tutor 2: Na aula 7 porque nessa aula aqui ele vai usar todo o conhecimento da aula $1,2,3,4,5,6$.

Pesquisadora: Anram

Professor-Tutor 2: Certo? Aqui, ó, no estudo de comportamento, ele vai usar... derivada a primeira, derivada a segunda.. Ele vai estudar, quando ele fala (...) derivada primeira, ele tem que aplicar... Se cair uma função no segundo grau, ele tem que saber estudo do sinal na função do segundo grau. Entendeu? Aí (...) uma segunda vez, pra saber... Aí, comportamento, cair uma função do $1^{\circ}$ grau, aí ele tem que saber estudo do sinal da função do primeiro grau. Então, tá entendendo? Aqui, ó, nessa aula 7, encaixa nisso aqui, certo? Todo, tudo o que ele foi estudado aqui pra trás, limite, continuidade, derivada, ele vai usar na aula 7... A pergunta num é essa, né?

Pesquisadora: Isso

Professor-Tutor 2: Como o intuito de propor, eu diria que... Essa aula 7 aqui, ela se encaixa. Ela, ela... Faz isso, sabe? Ela... Responde isso aqui.

Pesquisadora: Certo, mas e... Assim, nas outras áreas, em limite, derivadas... Derivada, o senhor fala mais, integral também, que chama, assim, o aluno pra discutir...

Professor-Tutor 2: Não, não é... Entendo. Mas o que eu digo, assim, eu quero dizer que é... $\mathrm{Na}$, quando ele tá estudando comportamento gráfico, ele já tá usando... Ele tem que saber tudo...

Pesquisadora: Aqui, é mais, é... a gente vê mais a presença do autor.

Professor-Tutor 2: Claro. Não, e outra coisa: ele, o aluno, tem que saber tudo de derivada. Pesquisadora: Sim.

Professor-Tutor 2: Tá entendendo? No comportamento aqui, ele vai, ele vai saber se ele estudou continuidade de... Se ele não sabe continuidade, se ele não estudou bem derivada, ele não vai fazer a aula 7 .

Pesquisadora: Anram, certeza.

Professor-Tutor 2: Tá entendendo ou não? A aula 7, aqui, é fundamental, é a aula mais interessante aqui. Aqui é o... tudo o que foi feito aqui nessa aula até a 6, se na sete.. É tanto que, quando a gente tá dando uma disciplina, a dificuldade é aqui, ó. Ele num andam, não. Aí, eles vão ver que não aprenderam derivada direito.

Pesquisadora: É. Verdade.

Professor-Tutor 2: Tá entendendo? 
Pesquisadora: Tô entendendo.

Professor-Tutor 2: E os conhecimentos de ensino... Esse conhecimento de função aqui, até, voltando atrás, uma coisa que falta aqui é estudo do sinal.

Pesquisadora: Aqui em funções.

Professor-Tutor 2: Ele não lembra. Lá em funções porque, novamente aqui, às vezes, né, quando você deriva uma função de grau 3, cai numa função de grau 2. Você vai usar o estudo do sinal pra saber onde ela cresce e descresce, ponto de inflexão.

Pesquisadora: Hunrum

Professor-Tutor 2: Era bom também voltando lá nesse introdutório aqui, novamente, ele ou colocasse aqui na introdução ou lá na .. No estudo do sinal das funções. Ok?

Pesquisadora: Eu sei. Como apêndice, né?

Professor-Tutor 2: Como apêndice, estudo dos sinais. Porque é importante, viu, o estudo do sinal.

Pesquisadora: Certeza, se não o aluno não vai...

Professor-Tutor 2: Não, é, exatamente. Por isso que eu digo, essa aula 7 aqui é tudo. Se encaixa isso aqui né? Tá entendo.. Você num tá perguntando isso aqui? É...

Pesquisadora: Isso

Professor-Tutor 2: Qual o que estimula? Olha, é esse estudo de comportamento do gráfico das funções. Ele vai estimular o aluno, exatamente, a voltar porque...

Pesquisadora: Ele vai construindo o saber aqui. Aí, chega aqui..

Professor-Tutor 2: Ele vai construindo. Quando ele chega aqui, aí ele vê e.. o que é que estimula. Porque ele vai ver o estudo do sinal, ele volta pro capítulo 1 . Porque ele vai ver que o estudo do sinal da função do segundo grau vai lá no capítulo 1 procurar. Aí, ele vai ver derivada: “Ah, rapaz, derivada da função seno, cosseno, aí eu vou voltar o capítulo de derivada". Tá entendendo ou não? Vai estimulando ele a..

Pesquisadora: A.. a retroceder..

Professor-Tutor 2: Retroceder no que ele já viu...

Pesquisadora: Pra ver o que ele..

Professor-Tutor 2: Pronto. Aí,..

Pesquisadora: O que ele tem mais segurança ou o que ele precisa estudar de novo

Professor-Tutor 2: De novo, né? Então, aqui, o capítulo 7, ele faz isso, né? O aluno, ele volta.

Ele chega aqui... Toda vida que ele tem que derivar uma primeira ou segunda vez, cai numa derivada que ele tá esquecido, ele volta o capítulo 2, capítulo 3. Certo? 
Pesquisadora: Hunrum

Professor-Tutor 2: Eu diria que seria isso aí, o capítulo 7.

Pesquisadora: Certo

Professor-Tutor 2: Ok?

Pesquisadora: Ok. A terceira pergunta..

Professor-Tutor 2: Hum

Pesquisadora: "3 - Em quais aulas no MD de Cálculo I se propõe ao aluno que faça uma sistematização dos conceitos aprendidos e induz o aluno a debater e discutir entre os seus pares?"

Professor-Tutor 2: É.. Mais uma vez, é o 7.

Pesquisadora: Certo.

Professor-Tutor 2: Agora, tem outros também. Por exemplo, se ele tiver aqui na, na derivada, na aula 4 , ele debate a aula 1.

Pesquisadora: Hunrum

Professor-Tutor 2: Porque, quando ele começa a estudar derivada, como eu digo lá, quando.. o maior problema é 0 sobre 0 , ou seja, uma indeterminação.

Pesquisadora: Anram

Professor-Tutor 2: Então, ele vai ter que aprender novamente a discutir aquilo que eu tô lhe falando.

Pesquisadora: Os conceitos de.. das aulas, né?

Professor-Tutor 2: De polinômios, de que tá faltando..

Pesquisadora: Tipo, essa revisão, né?

Professor-Tutor 2: É porque, é.. Se ele tem lá um polinômio, uma... uma função do $2^{\circ} \ldots$ Uma função de grau 2, que a forma fatorada da função do segundo grau é a (x-a).(x-b), ele vai discutir com o aluno, com o colega, né? Exatamente com eles.

Pesquisadora: Então, essa aula 1, aí, sobre revisão de funções é importante, né?

Professor-Tutor 2: É importantíssima, e é aí que eu tava faltando.. uma coisa fundamental, sobre polinômios. Forma fatorada de uma função do 20 grau não tem, estudo do sinal do segundo grau também não tem, polinômios.. São três coisas importantes que dá.. ele dá muito exercício de polinômio aqui. Tá entendendo?

Pesquisadora: Hunrum. Tô entendendo.

Professor-Tutor 2: Só que ele joga direto a forma fatorada, ele faz assim. Só que ele, era bom, que ele colocasse lá porque, como você tá perguntando aqui,ó.. né? Vai debater e discutir. 
Quando ele chega aqui, ele vai procurar aonde? Na fun.. Ele vai procurar porque aqui são conhecimentos de ensino fundamental. Então, ele vai procurar lá no.. no capítulo que tem. Aí, ele não encontra. "Rapaz, o polinômio de grau 3, aqui, como é que a gente vai baixar o grau dele, aqui, pra cancelar?"né? Quando tem: $\left(\mathrm{x}^{2}-1\right)\left(\mathrm{x}^{2}+1\right)$, né bem simples? Que é um produto notável conhecimento, mas se botar um polinômio de grau 3 sobre um de grau 1, ele tem que usar Briot-Ruffini e teorema do resto.

Pesquisadora: Hunrum. Exatamente.

Professor-Tutor 2: Então, é isso. Tá certo?

Pesquisadora: Tá certo.

Professor-Tutor 2: Eu acho, que, né.. deu pra entender?

Pesquisadora: Deu, deu pra entender, sim.

Professor-Tutor 2: Hunrum

Pesquisadora: É..4.

Pesquisadora: "4 - Em quais aulas você percebe o MD de Cálculo I sistematiza e formaliza de maneira adequada os conceitos ou problemas apresentados?"

Pesquisadora: Que ele faz aquele fechamento, assim, tentando resgatar toda aquela simbologia da matemática. Pra dizer: "Olha, a ente estudou isso aqui tudo pra chegar nisso aqui”.

Professor-Tutor 2: É..Eu, eu comparo sabe o que? Eu comparo, né, a aula 4, né, por exemplo, a aula 4 aqui, ele vai precisar desses três conceitos da aula 3 .

Pesquisadora: Isso

Professor-Tutor 2: Aula 1, 2 e 3. O estudo das derivadas, né, ó? Porque aqui você dizer que o (..) é tanto a aula 4 em relação às três primeiras, e a aula 7 em relação às 6 primeiras.

Pesquisadora: Hunrum

Professor-Tutor 2: Na aula 7, ele, vai acontecer isso aqui.. ele vai sistematizar e informatizar tudo o que ele aprendeu até aqui. Quando ele chegar nessa aula 4, ele vai ter que sistematizar o que ele aprendeu nas aulas 1,2 e 3.

Pesquisadora: Hunrum, é.

Professor-Tutor 2: Tá entendendo?

Pesquisadora: Tô entendendo.

Professor-Tutor 2: A aula 4 depende das 3 primeiras, a aula 7 depende das 6 primeiras e a oitava depende das 7 .

Pesquisadora: Hunrum. Porque a integração vai ser..

Professor-Tutor 2: Da integral. Pronto. 
Pesquisadora: Vai ser a ..

Professor-Tutor 2: Nessa, é... Nessa.. Tá entendo? Aqui tem 3 fases, aqui, nesse ponto. A aula 4: as três primeiras; a aula 7 em relaç.. e essa 8 em relação às 7 . Porque aqui, em integrais, ele vai ter que saber tudo.

Pesquisadora: Hunrum. É verdade.

Professor-Tutor 2: E ele vai, ele vai usar noções de..

Pesquisadora: Vai ter que estar afiado, né?

Professor-Tutor 2: É, porque até mesmo nas simplificações e ele tem que saber derivada porque, se ele não souber derivada, ele não integra, né?

Pesquisadora: É.

Professor-Tutor 2: Tá entendendo?

Pesquisadora: Verdade.

Professor-Tutor 2: Só que ele não vai precisar de limite. Ele tem que saber as regras de derivação, né?

Pesquisadora: É porque é como se fosse o...

Professor-Tutor 2: Já, já vai só usar.

Pesquisadora: É, como se fosse, não. É uma inversão, né?

Professor-Tutor 2: É uma inversão. Pronto.

Pesquisadora: De derivada e integral. Assim como mais é pra menos, divisão é pra multiplicação, derivada é pra integral.

Professor-Tutor 2: Pronto. Você entendeu aqui a pergunta? Tem três, tem três vezes, aqui, né? Quando ele usa isso aqui, né? O 4 puxa os 3 primeiros, o 7 puxa os 6 primeiros e a oitava puxa os 7 primeiros.

Pesquisadora: E ele consegue fazer isso? Essa...

Professor-Tutor 2: Ele consegue. Não... O livro, ele consegue. É bem, ó... se o aluno, o problema dos alunos eu já disse: tem que estudar.

Pesquisadora: Hunrum

Professor-Tutor 2: Ele nem, eles querem que a gente... Eu ajudo muito os alunos, mas se o aluno pegasse, pelo menos... Você sabe, né, que no computador é mais complicado, né? Se você, o livro não chega, você pegar um livro desse pra estudar é melhor, né? Claro, concorda? Pesquisadora: Certeza 
Professor-Tutor 2: Mas você, pelo computador, estudar, às vezes, aí a gente.. às vezes, o que é que eu faço: (...) nos polos (...) indico o Leithold que eles conseguem comprar, fica mais completo, que é uma referência desse livro aqui.

Pesquisadora: Tem polo que tem uma biblioteca boa, né? (...) área. Num sei se você já foi (...) Professor-Tutor 2: Pronto, exatamente! Aí, o Leithold é muito bom e esse livro aqui, ele tá bom. Muitos alunos: "Professor, o que tá faltando só alguns ajustes". Exatamente, alguns ajustes, mas ele tá bom.

Pesquisadora: Eu também acho.

Professor-Tutor 2: Ele tá bom, viu?

Pesquisadora: Os exercícios resolvidos, eles estão bons?

Professor-Tutor 2: Estão bons. Estão bons.. tem, tem que melhorar mais. É como eu te disse: na parte de limites, tá faltando adicionar. É só.. o que tá faltando aqui, eu já, eu sou conteudista.. Cálculo III tava dessa finura porque eu mandava 10 páginas, "Não professor. O senhor pode baixar pra 5". Quer dizer, já tá no.. é.. no.. você trabalha, né? Você sabe como é que são as coisas aqui.

Pesquisadora: Eu sei, eu sei como é que é.

Professor-Tutor 2: "Professor, num dá pra fazer assim não". Aí dá cento e tantas páginas, tem que baixar pra sessenta.. Aí o conteudista fica.. Rapaz, Cálculo I foi o melhor, o livro deles.. Ei, sabia que esse aqui foi o que teve mais folha? Nem o de Cálculo II e III...

Pesquisadora: É, eu sei. Foi uma luta com esse professor porque também ele queria fazer mais, a gente teve que baixar até pra, no máximo, vinte e (...), né? ...

Professor-Tutor 2: Não, mas ele, mas ele foi, é o que tá mais.. Mas aqui também é muita coisa também, né? Mas o outro também era coisa demais, a gente.. Mas ele tá bem, ele tá bem.

Pesquisadora: Anram, eu também acho.

Professor-Tutor 2: Em relação ao (Cálculo) 2 e 3, o material tá bom, sabe? Salvo algumas.. né?

Pesquisadora: Algumas.. ?

Professor-Tutor 2: Porque tá faltando algumas que eu botei, anotei no computador.. e estudar! O aluno só aprende matemática se resolver exercício.

Pesquisadora: É

Professor-Tutor 2: Ele num vai aprender derivar e integrar ou int.. ele não vai, ele não vai aprender a integrar se ele não aprender a derivar, num adianta.

Pesquisadora: Com certeza 
Professor-Tutor 2: Se ele (..) derivada.. é ou não é?

Pesquisadora: Certeza. Aproveitando aqui, porque o senhor falou muito do Leithold, né?

Professor-Tutor 2: Lethold. Porque é referência, é referência, exato.

Pesquisadora: E.. exatamente. Eu vi as referências e tem, além do Leithold, tem outros, mas..

Professor-Tutor 2: Tem o Thomas. O Thomas e o Guidorizzi. Dois bons.

Pesquisadora: O Guidorizzi e o Stewart, né? Que também falava muito..

Professor-Tutor 2: O Stewart. Pronto, não... Olha, o Guidorizzi é muito bom, o Guidorizzi é bom. Eu tenho, eu tenho os três lá em casa. Eu tenho, assim, eu tenho O Leithold, eu tenho todos eles.

Pesquisadora: Eu também tenho.

Professor-Tutor 2: O Guidorizzi é muito didático, o Stewart é muito didático... Todos eles são bons! Mas interessante que o Leithold, ele sai mais, não sei por que.

Pesquisadora: Eu acho que porque já é..

Professor-Tutor 2: Já é, eu acho..

Pesquisadora: ..referência pros nossos alunos, é isso?

Professor-Tutor 2: Né isso? Pronto. É. Eu não sei, mas..

Pesquisadora: Mas assim.. o senhor sabendo, o senhor.. acho que já deve ter lido cada um dos três, né?

Professor-Tutor 2: Já, trabalhei os três. Eu, eu consigo.. eu tenho os três..

Pesquisadora: Pois é. Aí, o senhor vê que o material se aproxima da abordagem de qual dos três?

Professor-Tutor 2: Se aproxima do Leithold.

Pesquisadora: Leithold, né?

Professor-Tutor 2: É. Eu, eu acho que ele aqui, ele, ele levou mais pro Leithold, viu? Eu acho, né? Eu conheço os três... Mas assim, mas tu sabia que o Stewart, eu acho assim.. O Leithold, o Guidorizzi e o Stuart, eles têm muito o estilo parecido de exercício resolvido, sabia? Agora.. Pesquisadora: É, a abordagem do conceito, dos conceitos são, é diferente, mas..

Professor-Tutor 2: A abordagem eu acho que.. É... Agora, eu, eu acho o Leithold mais didático, mas o que o Guidorizzi e o Stuart eles são... Não são tão didáticos quanto o Leithold. O Leithold detalha mais, sabe?

Pesquisadora: É

Professor-Tutor 2: Tem certas coisas lá no Guidorizzi que ele pula.

Pesquisadora: É 
Professor-Tutor 2: Ele pula, aí o aluno vai no Leithold: "Professor, não entendi.." Porque o Guidorizzi, ele pula etapa e o Leithold, ele vai lá mostrar ponto de inflexão, ele explica, ele abre um espaço e pergunta "Ó porque que não é, porque que é", aí o aluno gosta exatamente disso aí.

Pesquisadora: Anram.

Professor-Tutor 2: Que, coisa que não tem nem no Guidorizzi, nem no Stewart, né? E nem no Thomas. O Thomas ainda tem até parecido... O que mais se parece, se assemelha, na verdade, é o Thomas, eu acho.

Pesquisadora: Eu não cheguei a pegar o Thomas.

Professor-Tutor 2: O Thomas. O Thomas, ele se assemelha ao Leithold. Certo?

Pesquisadora: É bom saber.

Professor-Tutor 2: Nesse ponto aí de, de dar.. detalhar bem. Por isso que eu indico o Leithold, porque ele detalha. $\mathrm{O}$ aluno... Até mesmo pra gente, que é professor, quando vai dar uma disciplina, que vai preparar aula, é bom. Né?

Pesquisadora: Hunrum. É. Leithold é como se fosse a bíblia

Professor-Tutor 2: Porque ninguém sabe de tudo. É a bíblia. Todo professor de matemática tem Leithold. Toda...

Pesquisadora: É verdade.

Professor-Tutor 2: Pronto.

Pesquisadora: Bem, a última pergunta só pra fechar, né, a quinta.

Professor-Tutor 2: Certo.

Pesquisadora: "5 - Como e onde você percebe que o MD de Cálculo I consegue transformar os saberes científicos ensinados em saberes aprendidos?"

Pesquisadora: Né, porque isso aqui, limites, derivada e integral são coisas já de alto nível.

Professor-Tutor 2: É. Não, é.. eu acho assim.. eu percebo é quando ele consegue aqui, no capítulo 8 , certo?.

Pesquisadora: Hunrum

Professor-Tutor 2: Encaixar os conceitos de derivada, né? Ele, ele, ele.. porque, na verdade, o que.. isso aqui responde o capítulo 8. Porque, quando ele chega em integral, o aluno já tem que ter consciência, tem que ter.. tem que ter relembrado o que? Os conceitos de f.. preliminar de função t.. de ensino médio, essas coisas que ele falou aqui, e derivada, certo? E limite. Então, isso aqui, olha, eu percebo que consegue transformar é no capítulo 8. Pronto. Integral. Certo? 
Pesquisadora: É, esse é o objetivo, né?

Professor-Tutor 2: O objetivo é esse, né? Porque, quando você chega em integral, o aluno tem que ter sistematizado em derivada bem, mas, pra ele sistematizar derivada, ele tem que ter sabido o que? Tem que saber o que é um limite, esses conceitos de ensino médio...

Pesquisadora: Função, né? Tem que ter.. uma coisa que eles tem que...

Professor-Tutor 2: Função, tudo. É.. alguns, alguns teoremas aqui que eu, que eu sei que eu não falei assim, no capítulo 6, por exemplo: Teorema de L'Hospital, são teoremas que auxiliam, né? Mas essas coisas aí todas, elas.. elas fazem parte da derivada, é o estudo da derivada, né? Fecha na integração porque, na integração, é isso. Eu dei Cálculo 3 agora e alunos disseram: "Professor, a gente aprendeu cálculo 3 porque.." eles tiveram dificuldades no cálculo II porque o professor faltou, não foi aos encontros eles eram meio complicado. E aí, eu, eu relembrei várias coisas.. técnicas de integração, por parte, essas coisas.. Porque a, a integral.. essa.. a integração é a hora certa do professor, até, ensinar derivada ao aluno.

Pesquisadora: Anram

Professor-Tutor 2: Né? Se você enten... se o aluno souber derivada, você aproveita a integração pra..

Pesquisadora: Assim, se ele não entendeu aquele momento (..) ..

Professor-Tutor 2: Aquele, é.. que ele viu? Pronto. Aí, o que é que você faz? Na integração..

Pesquisadora: .. que acontece muito, né? Assim, o aluno, ele vai construindo o saber, aí, naquele momento, ele não vai amadurecer pra.. pra aprender aquilo, né?

Professor-Tutor 2: É, pronto. Exatamente. Pronto.

Pesquisadora: Mas, em outro momento, que ele faz a conexão, aí ele: “Ah! Agora entendi, aqui".

Professor-Tutor 2: Que é exatamente no capítulo 8. É aí que ele vai saber a importância da derivada, vai.. quando ele passou aqui por derivada, por limite, ele só resolveu exercício. Mas quando ele for integrar, diz: "Não, agora, por tem que saber derivar".

Pesquisadora: Por que daquilo, né? Assim?

Professor-Tutor 2: Exatamente! O porquê, né? E ele demonstra, aqui, algumas.. integrais importantes, sabe?

Pesquisadora: Hunrum

Professor-Tutor 2: É importante, é legal. O, o.. a parte de integral tá bem.. tá aqui. Ele dá algumas, né, tá todas.. resolvidas, explica, demonstra algumas.. tá interessante, tá boa. Viu?

Pesquisadora: Tá certo. 
Professor-Tutor 2: A parte de integração. Fe.. essa pergunta aqui fecha o capítulo 8.

Pesquisadora: 8 , que chega a.. ao objetivo principal da disciplina.

Professor-Tutor 2: É, o objetivo do cálculo é isso.

Pesquisadora: Aprender integração

Professor-Tutor 2: É. O objetivo do professor e do cálculo é, quando eu chegar em integração, que ele saiba derivada. Na verdade, é.. o foco é o quê? Limite, integ.. derivada e integral. Então, na verdade, o que ele tem que saber é limite e derivada. Só que, aí, tem aquele buraco lá do ensino médio, como eu lhe falei.

Pesquisadora: Anram

Professor-Tutor 2: Estudo do sinal, tem o polinômio, tem o.. esses teoremazinhos de $2^{\circ}$ grau, às vezes, você acredita, que você.. você manda calcular integral entre duas curvas, parábolas, que é a integral.. você tem uma parábola côncava pra cima e o outra pra baixo, e ele é bem simples. Aí, eles têm quem desenhar o gráfico.. passar, eu mando desenhar o gráfico. Que esse.. eles fazem a intersecção de uma equação biquadrada, pega os (..). Mas, se eu mandar desenhar o gráfico, eles não sabem. Tem dificuldade de desenhar uma parábola pra cima.. quer dizer, é exatamente, ó, a.. o.. onde é que tá o foco aí assim? É a.. ele tá calculando integral, mas ele não sabe o.. ele passou pelo ensino médio.. É, por isso que é importante nessa aula 1, né, alguns gráficos, também, ele faz.. mas a gente, quando dá aula no presencial, eles relembram, sabe, gráfico? Né?

Pesquisadora: Hunrum

Professor-Tutor 2: Só que, no a distância, ele tem que ser tudo mesmo..

Pesquisadora: Passo a passo

Professor-Tutor 2: Passo a passo, né? Assim.. Num, num.. pe.. Taí, ó, faz gráfico de parábola aqui, ó, côncavo pra baixo, côncavo pra cima, né?

Pesquisadora: Hunrum, é.

Professor-Tutor 2: Tá entendendo?

Pesquisadora: Tô entendendo.

Professor-Tutor 2: Então, é, é, é.. essa $5^{\text {a }}$ pergunta se encaixa no capítulo 8.

Pesquisadora: Pronto, é..

Professor-Tutor 2: Eu acho que..

Pesquisadora: Isso que.. já deu um norte, assim, porque se.. futuramente, quando for melhorar o material, aí eu vou utilizar isso já..

Professor-Tutor 2: É, não. E você tá fazendo um trabalho científico. 
Pesquisadora: Também.

Professor-Tutor 2: Você vai transformar isso aí em palavras, pelo professor que já deu a disciplina, quem tem experiência.. é interessante.

Pesquisadora: Exatamente.

Professor-Tutor 2: Às vezes, o outro professor pode ter uma visão totalmente diferente da minha, isso é que é interessante. Concorda ou não?

Pesquisadora: Hunrum

Professor-Tutor 2: Aí é que tá a discussão. Ele pode dizer que o material não presta, na visão dele.

Pesquisadora: Pois é..

Professor-Tutor 2: Né assim?

Pesquisadora: Se tivesse acontecido o grupo focal, ia ser bem mais impressionante..

Professor-Tutor 2: É interessante, ó..

Pesquisadora: .. mas, infelizmente, não deu certo.

Professor-Tutor 2: Né, porque, aí, uma visão que eu tenho ele pode não ter.

Pesquisadora: Exato

Professor-Tutor 2: Ele já pode dizer: "Professor, eu discordo disso aí". É interessante o grupo focal, né? Porque a discussão ficava bem rica, né não?

Pesquisadora: É, exatamente. Só que ia juntar.. juntar as pessoas é complicado, né?

Professor-Tutor 2: É, complicado..

Pesquisadora: Ainda mais quando elas têm horários diferentes.

Professor-Tutor 2: Mas você.. mas, opa, desculpa aí.. Mas num tem erro não, viu?

Pesquisadora: Não, tudo bem.

(Telefone tocando)

Professor-Tutor 2: Alô? Diga. Opa. Tá, tudo bem. Não, eu já fiz foi sacar. Eu sou ligeiro. Tá bom, viu? Obrigado.

Professor-Tutor 2: Sim, viu, ô, Marília, tá aí, interessante.

Pesquisadora: É..

Professor-Tutor 2: Mas deu pra, deu pra..

Pesquisadora: ..deu pra pegar algumas coisas na entrevista.

Professor-Tutor 2: Deu pra.. se você quiser mais alguma coisa, aí, mas eu acho que o..

Pesquisadora: É isso.

Professor-Tutor 2: .. as perguntas foram isso. Aí, você depois.. 
Pesquisadora: É isso..

Professor-Tutor 2: ..tá tudo gravado, você vai tirando as palavras e transformando em.. né?

Pesquisadora: Pronto, professor, era isso mesmo. Obrigada, viu? Desculpa se, eu ter ligado várias vezes..

Professor-Tutor 2: Não.. Mas eu sei, Marília, eu sei o que é isso. Eu sofri pra fazer meu mestrado atrás de aluno pra entrevista, professor.. Eu ajudo as pessoas, tá entendendo? Pesquisadora: Tô entendendo. E eu agradeço mesmo.

Professor-Tutor 2: É importante esse mestrado pra você, você entra aqui.. Se você entrar agora, só a graduação.. é.. 


\section{A P Ê N D I C E I V - TRANSCRIÇÃO DA ENTREVISTA COM O PROFESSOR- TUTOR 3}

Pesquisadora: É... De início, era para ser um grupo focal, como eu falei para o senhor, mas tanto o senhor como os outros tutores (professores) também não puderam ter um 'denominador comum' entre os horários, né? Ficou difícil juntar todos os professores (tutores) para um mesmo horário.

Professor-Tutor 3: ...Difícil é ser professor, né? Pra juntar no mesmo horário.

Pesquisadora: Exatamente. Aí, então eu decidi fazer entrevistas, eu falei antes com a minha professora orientadora, né? "Professora, olha, não tá dando certo juntar os tutores num mesmo horário, né? Então, eu vou fazer entrevista". Aí ela: "Não, tudo bem. Então faça”, né? A entrevista é sobre o material didático de Cálculo I, né? Que vocês utilizaram como (material) do curso. Você foi tutor em 2013.1, né, se não me engano?

Professor-Tutor 3: Foi.

Pesquisadora: Aí, como vocês utilizaram e também os alunos utilizaram (o material didático de Cálculo I), A gente (a pesquisadora e a orientadora)... Decidimos fazer uma pesquisa com foco no professor tutor, né?

Professor-Tutor 3: Certo.

Pesquisadora: Já que você ensina Cálculo I, não só aqui, como em outras instituições, né?

Professor-Tutor 3: Anram.

Pesquisadora: E... Talvez você tenha usado o material didático, não sei. É, aí.. Pra início de conversa, você concorda em fazer a entrevista?

Professor-Tutor 3: Concordo, plenamente.

Pesquisadora: É, a gente não vai, é... Citar seu nome na pesquisa, sempre vai ser professor "x", “y”, "a", "b", né?

Professor-Tutor 3: Certo.

Pesquisadora: Justamente pra gente...

Professor-Tutor 3: O anonimato, né?

Pesquisadora: Isso, o anonimato. Pronto. Pra gente preservar o seu nome, certo?

Professor-Tutor 3: Certo.

Pesquisadora: Então, tudo o que for falado aqui vai ficar só entre eu e você, na gravação, mas não vai ser, é.. Divulgado em outros meios, não. Certo? 
Professor-Tutor 3: Certo. Você só vai, no caso, transcrever pra sua dissertação, alguma coisa, né?

Pesquisadora: Exatamente. É. Sempre colocando outro nome para o senhor.

Professor-Tutor 3: Certo.

Pesquisadora: Certo?

Professor-Tutor 3: Tudo bem.

Pesquisadora: É... Então, assim. Eu fiz cinco perguntas. À medida que eu for fazendo as perguntas você vai tentando responder com base nas experiências com o uso do material didático, né? E a gente vai vendo como é que vai se dar o andamento das respostas, certo?

Professor-Tutor 3: Hunrum.

Pesquisadora: Aqui. Sobre ã.. Primeira questão, né? Ou melhor, desculpa, primeira pergunta.

DESTE PONTO EM DIANTE A ENTREVISTA SEGUIU FORMALMENTE COM PERGUNTAS DIRECIONADAS SEGUNDO O ROTEIRO

Pesquisadora: "1 - O MD de Cálculo I abrange todo o conteúdo de limites, derivadas e integrais em uma única variável. Onde esse material didático consegue facilitar o ensino desses conceitos através de uma abordagem didática dos conteúdos explorados?".

Professor-Tutor 3: Olha, no meu ponto de vista, certo, o material, ele deveria ter mais exemplos, entendeu? Ele é muito extenso, assim, para as turmas da $\mathrm{EaD}$, certo?

Pesquisadora: Hunrum.

Professor-Tutor 3: É um pouco extenso. Ele é, ele tem todos os conteúdos, certo, de limite, de derivadas e de... No final, acho que ele se...

Pesquisadora: De integral.

Professor-Tutor 3: de integral também, só que pra o nível dos nossos alunos da EaD ele deveria ser um pouco mais didático, certo?

Pesquisadora: Hunrum.

Professor-Tutor 3: Ele deveria exemplificar mais. Eu acho que os exemplos são muito pobres. Assim tem que ter pelo menos uns quatro, cinco exemplos, né, de cada tópico, assim, bem explicado, detalhe por detalhe porque a dificuldade em Cálculo I é grande não devido aos, ao Cálculo I, mas devido à base deles do ensino fundamental. Eu sempre digo isso: à base do ensino fundamental porque a dificuldade não está no cálculo; a dificuldade está lá no ensino fundamental. Tem fatorar, produto notável. Aí, começa a entrar no ensino médio, ele não tem noção de polinômios, ele não tem noção de função, ele não consegue fa.. Encontrar uma raiz, 
ele não consegue fazer um cálculo simples de simplificação e junta tudo isso, que ele não tem a base fundamental, com a base do ensino médio, e o cálculo exige muito isso: que você chegue com a base bastante boa. Ou então se criasse um "pré-Cálculo", né? Seria outra sugestão, criasse um "pré-Cálculo" antes do Cálulo I, pra poder dar essas noções, já que os nossos alunos realmente chegam sem essa noção, porque é complicado. Esse é meu ponto de vista, entendeu? Que...

Pesquisadora: Eu sei.

Professor-Tutor 3: A matéria poderia ser um pouco melhor nesse sentido, de exemplos, entendeu?

Pesquisadora: Eu sei.

Professor-Tutor 3: De que, quanto mais exemplos, nunca é demais, principalmente com a nossa clientela.

Pesquisadora: Eu sei. Mas eu digo assim: com relação aos conceitos que são abordados em limites, derivadas e integrais... A abordagem no material didático, assim, a introdução que o autor faz, né? No material didático, ele é didático, ele consegue introduzir de uma forma legal ou ele não atingiu esse objetivo?

Professor-Tutor 3: Eu acho que poderia ser mais claro, entendeu?

Pesquisadora: Poderia ser mais claro.

Professor-Tutor 3: A abordagem está muito complexa, como eu disse no início, muito complexa. Se fosse um aluno de bacharelado, talvez, de matemática, a linguagem é muito complexa. Poderia ser uma linguagem mais simples, entendeu?

Pesquisadora: Mais acessível.

Professor-Tutor 3: Poderia, poderia ser. Num é que vá fugir dos conceitos, mas uma linguagem mais simples para o aluno que tá lendo, entender. A abordagem é muito complexa, não sei por quê...

Pesquisadora: Pra quem estuda sozinho.

Professor-Tutor 3: Pronto. Pra quem estuda sozinho, a abordagem é um pouco complexa.

Pesquisadora: Já que, de certa forma, o aluno vai tá, ele e o material didático e...

Professor-Tutor 3: Pronto.

Pesquisadora: ... Ele vai só se reportar ao professor tutor quando ele tiver dúvidas, né?

Professor-Tutor 3: Exatamente. Então, na minha opinião, poderia ser bem mais simples. E isso não é só no Cálculo I, não. Nos outros Cálculos também a dificuldade é a mesma. Começa com a teoria muito pesada, muito abstrata pro aluno. Certo? 
Pesquisadora: Anram. Entendo. Na segunda:

Pesquisadora: "2 - Onde e como você percebe que o MD de Cálculo I estimula o aluno nas discussões sobre certo conceito matemático estudado e explorado, com o intuito de propor ao estudante o desenvolvimento de argumentações sobre o raciocínio?"

Pesquisadora: Onde é que ele traz o aluno, assim, pra discutir sobre o conceito que tá sendo estudado.

Professor-Tutor 3: Eu não vejo muito isso. Eu vejo, assim, mais, quando você tem naqueles "Você Sabia?". Nessa parte aqui, é que dá, dá assim a sugestão do aluno tentar se aprofundar, tentar é... Ter ânimo de estudar, certo? Nesse material, quando ele tem a curiosidade de ver "Você Sabia que o lugar geométrico...?", aí isso aqui dá uma desperta... Eu acho que essa parte de "Você Sabia?" aqui, ela...

Pesquisadora: É. São os ícones.

Professor-Tutor 3: Exatamente. Esse 'iconezinhos' aqui, e alguns exemplos também despertam, ou seja, eu só vejo...

Pesquisadora: Mas em qual parte o senhor viu, assim, que tem mais, assim, presença, se é em limites, derivadas ou integrais?

Professor-Tutor 3: Ah, no conteúdo, né, que você tá dizendo né?

Pesquisadora: É.

Professor-Tutor 3: Ah, então é na parte de derivadas.

Pesquisadora: Derivadas, ele chama mais o aluno pra discutir.

Professor-Tutor 3: Chama. Chama muito mais. O limite, ele fica muito solto, assim. Agora a parte de derivadas tem mais aplicações que chama ele mais a "Ah! Eu tenho que relacionar aquilo que eu estudei lá no ensino médio, no ensino fundamental...”. Porque tudo ali são casos particulares. Porque tudo que você estuda ali no fundamental e no ensino médio são casos particulares do Cálculo. Aí, pra ele ter essa ligação, aí é mais na parte de derivadas.

Pesquisadora: De derivadas. Ah, que bom. A terceira pergunta:

Pesquisadora: “3 - Em quais aulas no MD de Cálculo I se propõe ao aluno que faça uma sistematização dos conceitos aprendidos e induz o aluno a debater e discutir entre os seus pares?"

Professor-Tutor 3: Principalmente, naquela parte de aplicações, certo, das derivadas.

Pesquisadora: Das derivadas. Né?!

Professor-Tutor 3: Aplicações das derivadas. 
Pesquisadora: Tem aqui o sumário pro senhor... Que as derivadas vai começar na aula 4, né? A aula 1 é "Funções", a aula 2 e 3 falam sobre limites, exclusivamente, né? A aula 4, da 4 até a 7 é sobre derivadas.

Professor-Tutor 3: Pronto. A aula 5, ó, certo - que tem as taxas relacionadas - e a aula 6 - que são os valores máximos, os valores mínimos, teorema do valor médio - essas duas aulas aqui, ó, são as que mais... certo? E também a 7, também, que é a parte do gráfico. Pronto. Essas três aulas aqui, ó: 5, 6 e 7, são, vamos dizer assim, o carro chefe aqui, ó, do...

Pesquisadora: Ela chama o aluno pra fazer discussão sobre os conceitos que ele deveria ter aprendido em limites e também trazidos de outras épocas acadêmicas.

Professor-Tutor 3: Pronto. Exatamente! Essa... Quando chega aqui que o engodo começa, entendeu? Aqui o engodo começa mais do que aqui porque aqui ele vai exigir dele uma bagagem grande, além dele já ter visto limite, ele vai ter que ter uma base boa muito grande de funções, e essa aula 1 aqui é uma aula, assim, muito simplificada e de funções, apesar que o pessoal questiona bastante assim: "Não, mas ele já viu a matemática básica 1 , no $1^{\circ}$ semestre, porque o Cálculo 1 é só visto no $2^{\circ}$. Então ele já tem uma certa base, ele já estudou funções, todas as funções. Ele já fez a revisão, né? Na matemática básica 1”, certo? Mas não é suficiente. Ele teria que ter uma base boa em cima disso aqui.

Pesquisadora: É, eu sei. E a questão quatro:

Pesquisadora: "4 - Em quais aulas você percebe o MD de Cálculo I sistematiza e formaliza de maneira adequada os conceitos ou problemas apresentados?"

Pesquisadora: Quando ele faz o fechamento aqui, né, ele introduz, né, primeiramente. Depois, ele tenta fazer com que o aluno discuta, né? Depois ele traz o aluno a fazer um debate entre seus pares, e agora, assim, pra fechar assim, ele, como é que ele faz? Ele aborda o material didático? Uma forma que ele sistematiza todos aqueles conceitos que ele foi sendo construído. Professor-Tutor 3: Em que aulas, né?

Pesquisadora: É. Exatamente. E ele formaliza, assim, de uma forma matemática.

Professor-Tutor 3: Na verdade, era pra ser no final de cada aula ele ter isso aí, né? Mas vamos dividir assim, vamos dividir. Limite, derivadas, certo? Em limite, ele faz na aula 3, certo? É a sistematização final, porque na aula 3 ele já tem que ter todos os conceitos pra estudar assíntotas, ou, horizontais e verticais, a extensão que ele já estudou, e as propriedades. Então na aula 3 , ele tem que ter aqui o resumo do limite, e na aula 7 , o de derivada, certo? $\mathrm{O}$ de integral só é o começo, só a introdução, né?

Pesquisadora: Isso. Exatamente. Na aula 8. 
Professor-Tutor 3: Na aula 8. Como esse curso já é de 100 horas, então são 10 aulas, então a aula 10 ele fecha, que são as aplicações da integral.

Pesquisadora: E ele consegue fazer isso? Em cada aula? Ou você acha que ele precisa fazer mais, assim, ele tem que dar aquela formalizada, aquela sistematizada, assim, dos conceitos?

Professor-Tutor 3: No meu ponto de vista, precisa também, como eu disse no início, fechar melhor, assim... Tanto abrir, quanto fechar de forma mais clara, certo? Porque, quando ele começa a aula naquela parte muito teórica e aí o aluno vai lendo, ele não vai entendendo aquela abstração todinha, e aí, no final, ele não vai entender porque ele não conseguiu... Não conseguiu, na cabeça dele, abstrair tudo aquilo pra poder, no final, sistematizar. Então é muito difícil.

Pesquisadora: Em quais as áreas ele, você acha que o aluno poderia... O aluno poderia sentir mais dificuldade? Limites, derivadas ou integrais?

Professor-Tutor 3: Em limite, mais do que a derivada e a integral. Abstrair limite é uma coisa difícil pro aluno, certo? Ainda... Eu já passei por várias turmas, presenciais e a distância, e fica difícil a pessoa dizer assim: "Rapaz, tende ser aquilo, mas não é aquilo". "Mas como é que é isso: tende ser, mas não é?". E aquele... Entendeu? Então, você tem que ter uma abordagem (Didática)... Por isso, que eu digo a questão de alguns exemplos, né, pra você conseguir definir um conceito de "épslon" e de "delta", porque quando você começa aquele conceito abstrato de "épslon" e "delta"... Eu não começo com "épslon" e "delta". Eu começo com exemplos pra depois tentar abstrair aquele conceito. Entendeu?

Pesquisadora: Anram. É.

Professor-Tutor 3: E ainda é difícil. Entendeu? E ainda é difícil.

Pesquisadora: Aproveitando esses conceitos abstratos que você falou sobre "épslon" e "delta".,. Nas referências, tem três autores que ele cita, né? Tem outros, mas esses três, assim... São os mais usados na graduação, que os alunos até dizem, né, que os professores recomendam que é os livros do Leithold, o Guidorizzi e o Stewart, né? Você acha que o livro, ele tá mais alinhado com qual autor, assim, você sentiu mais abordagem de quem? Que o próprio autor aqui, desse material didático, ele, que ele... Às vezes, você vai estudando, né, tanto um, como outro livro e você vai acabando se alinhando com a abordagem daquele autor. Professor-Tutor 3: Com o do Leithold, eu tenho certeza que não tá, certo? Com o do Leithold, no meu ponto de vista. Tá mais para o Stewart... O do Guidorizzi é um livro bom também, certo? E, assim, eu ainda acho, eu não sei, assim, qual é a linha de trabalho pra essa teoria ser tão pesada, entendeu? Porque, o Guidorizzi, ele tem uma teoria pesada, mas não é tão 
abstrata, tão complicada assim, entendeu? Tem uma teoria fácil de entender. Mas o Stewart, eu não costumo muito trabalhar com Stewart, eu tenho uma... Talvez ele esteja mais se aproximando mais com o Stewart, na minha opinião. Isso aqui é muito... Eu vejo assim, se eu fosse um aluno que nunca tivesse visto Cálculo e pegasse isso aqui, a partir dessa aula.., a partir da aula 2 e 3, eu já ia ficar voando no espaço, né? Já ia ficar voando no espaço. Se eu não tivesse uma noção boa, já ia ficar voando porque começa com uma teoria muito... Isso no meu ponto de vista, né? Uma teoria muito pesada.

Pesquisadora: Eu sei. Bem, pra última pergunta, né? Pra fechar.

Pesquisadora: "5 - Como e onde você percebe que o MD de Cálculo I consegue transformar os saberes científicos ensinados em saberes aprendidos?"

Pesquisadora: Porque essa parte de cálculo é matemática avançada, né? Como é que você acha que o aluno aprendeu? Assim...

Professor-Tutor 3: Seria, no meu ponto de vista, ele me mostraria que estaria aprendendo quando ele conseguisse relacionar aquilo que eu lhe disse. Ele chegasse e conseguisse relacionar "Ah... Quer dizer que essa teoria aqui que eu tô estudando tem tudo a ver com o fundamental e com o médio", né? "Quer dizer que essas derivadas, essas construções desses gráficos, o cálculo dessas áreas...”, quando ele conseguir relacionar que essa teoria aqui é, está ligada ao que foi visto no ensino fundamental e no ensino médio, que eu, diga-se de passagem, eu não vejo aqui nesse material nenhuma relação com isso, assim... Pra ele chegar e mostrar que "o valor máximo da função do segundo grau...". Eu sempre (...) "Rapaz, aquele valor máximo, valor mínimo que você tá estudando está relacionado com o Cálculo I, está relacionado com o caso particular da função do segundo grau...”

Pesquisadora: Né? Na parábola e tal.

Professor-Tutor 3: Pronto. Aqui você está estudando a generalização para qualquer função. Então, quando ele conseguir, eu não vejo isso no material... Quando ele conseguir relacionar isso aí, esse estudo do cálculo e que possa, além de ele ver isso aí, possa abrir um leque... “Ah, então quer dizer que eu posso estudar, além disso, aqui”, né? Veem outras possibilidades do Cálculo I, quando ele conseguir relacionar o que foi visto antes e que, futuramente, ele vai ver que são de duas, três e " $n$ " variáveis...

Pesquisadora: Exato.

Professor-Tutor 3: Quando ele conseguir 'acender essa lâmpada na cabeça' dele, aí sim, ele vai dizer: "Ah, agora eu tô entendendo o cálculo realmente".

Pesquisadora: Que o material tá... 
Professor-Tutor 3: "Que o material tá me fazendo entender isso, que..”. Eu também não vejo aqui, é, ele despertar, assim, "Para futuras...", é.., Cálculo II. Dizer assim, ó: "Vai ter..." Pesquisadora: Fazendo uma ligação com as outras disciplinas.

Professor-Tutor 3: Isso, pronto. Fazer a interdisciplinaridade ou então uma contextualização, ou então ligar com a Física, né? Ou, então, abrir um próprio leque para duas variáveis, né? Dizer assim: "Ó, a gente vai estudar isso aqui..."

Pesquisadora: Já preparando a mente do aluno.

Professor-Tutor 3: Isso, pronto. Preparando a mente do aluno pra ele dizer assim: “Ah! Quer dizer que o que eu tô estudando aqui com uma, eu vou ter a oportunidade de ver isso aqui com duas, com três variáveis, com mais de uma variável". Então, ele vai despertar... Porque ele pode pensar assim: "Não, parei no Cálculo I. Pronto. Quer dizer que só tem o estudo de uma variável". O aluno da graduação...

Pesquisadora: É. Pra não ficar dissociado, né? Cálculo I é uma coisa, Cálculo II é outra... Não. Cálculo, num todo, é um estudo, é uma área de estudo, né? Aí as subdivisões em cálculo I, Cálculo II são coisas didáticas.

Professor-Tutor 3: Pronto. E falando em coisas didáticas, isso aí pode até ser repensado, isso aí vai depender muito de um grupo, essa discussão de Cálculo é muito interessante, por exemplo: a UFC, ela só... Ela dividiu os cálculos dela em: Cálculo Diferencial - só o estudo do Cálculo Diferencial, não mistura com integral - e um cálculo só de integrais, um cálculo de integral. É como ele dividiu os cálculos não é em Cálculo I, Cálculo II, Cálculo III. Ele dividiu: Cálculo Diferencial I, Cálculo Diferencial II, Cálculo Integral I e Cálculo Integral II. Ele faz essa divisão. Ele não mistura. Não sei até que ponto é, seria bom. É uma coisa pra se discutir.

Pesquisadora: Hunrum.

Professor-Tutor 3: Entendeu?

Pesquisadora: Eu sei. Aí, isso aí já é uma...

Professor-Tutor 3: Uma discussão mais ampla.

Pesquisadora: Isso. Tem que ser com as coordenações.

Professor-Tutor 3: É, com as coordenações, entendeu?

Pesquisadora: Pronto. Então é isso, professor, que eu queria fazer. São essas 5 perguntas. Eu acho que rendeu, né?

Professor-Tutor 3: Então pronto. Espero que... 
Pesquisadora: Vai me ajudar tanto na pesquisa, como também em futuras melhorias no próprio material didático, né?

Professor-Tutor 3: É. Aí, eu espero ter contribuído. Que possa lhe ajudar e, qualquer coisa, eu tô à sua disposição aí, viu, Marília?

Pesquisadora: Tá. Obrigada, viu, professor?

Professor-Tutor 3: Obrigado todo meu.

Pesquisadora: Desculpa aí perturbar várias vezes.

Professor-Tutor 3: Não. Que é isso. Eu que peço desculpas a você que é um corre-corre... 
ANEXOS 


\section{ANEXO I - PUD DE CÁLCULO I}

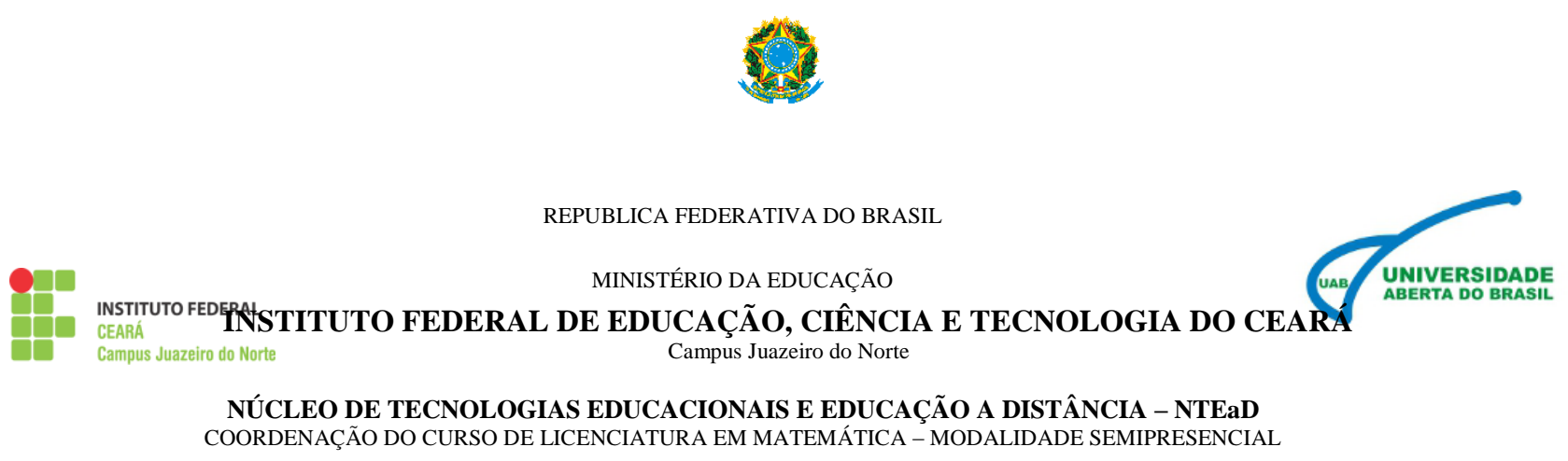

PROGRAMA DE UNIDADE DIDÁTICA - PUD

\section{DISCIPLINA: Cálculo I}

Código: MAT. 061

Carga Horária: 100h

Número de Créditos: 5

Código pré-requisito: MAT. 055

Semestre: $2^{\circ}$ semestre

Nível: Graduação

Professor responsável

\section{EMENTA}

Definição de Limites e operações e teoremas, Continuidade, Derivada e aplicações da derivada, A integral de Riemann, Técnicas de integração, Curvas e comprimento de curvas e aplicações.

\section{OBJETIVO}

Aplicar as idéias e os conceitos de funções de uma variável real; Entender e aplicar o conceito de limites; Compreender o que é continuidade de uma função e aplicar esse conceito; Saber a definição de derivada e fazer as relações da derivada com questões práticas; Esboçar o gráfico de uma função conhecendo as derivadas dessa função; Saber integrar e aplicar a integral no cálculo de áreas; Representar uma curva no plano e aplicar a derivada para tirar informações sobre essa curva.

\section{PROGRAMA}

- Limite e Continuidade de funções de uma variável real

○ O limite de uma função real

$$
\begin{aligned}
& \text { - } \quad \text { Noção intuitiva de limite } \\
& \text { - } \quad \text { Pefinição e exemplos } \\
& \text { - } \quad \text { O Teorema do Confronto dos Limites } \\
& \text { - } \quad \text { Limites infinitos e limites no infinito. }
\end{aligned}
$$

○ Continuidade de funções reais

- Noções intuitiva de continuidade

- Definição e exemplos 


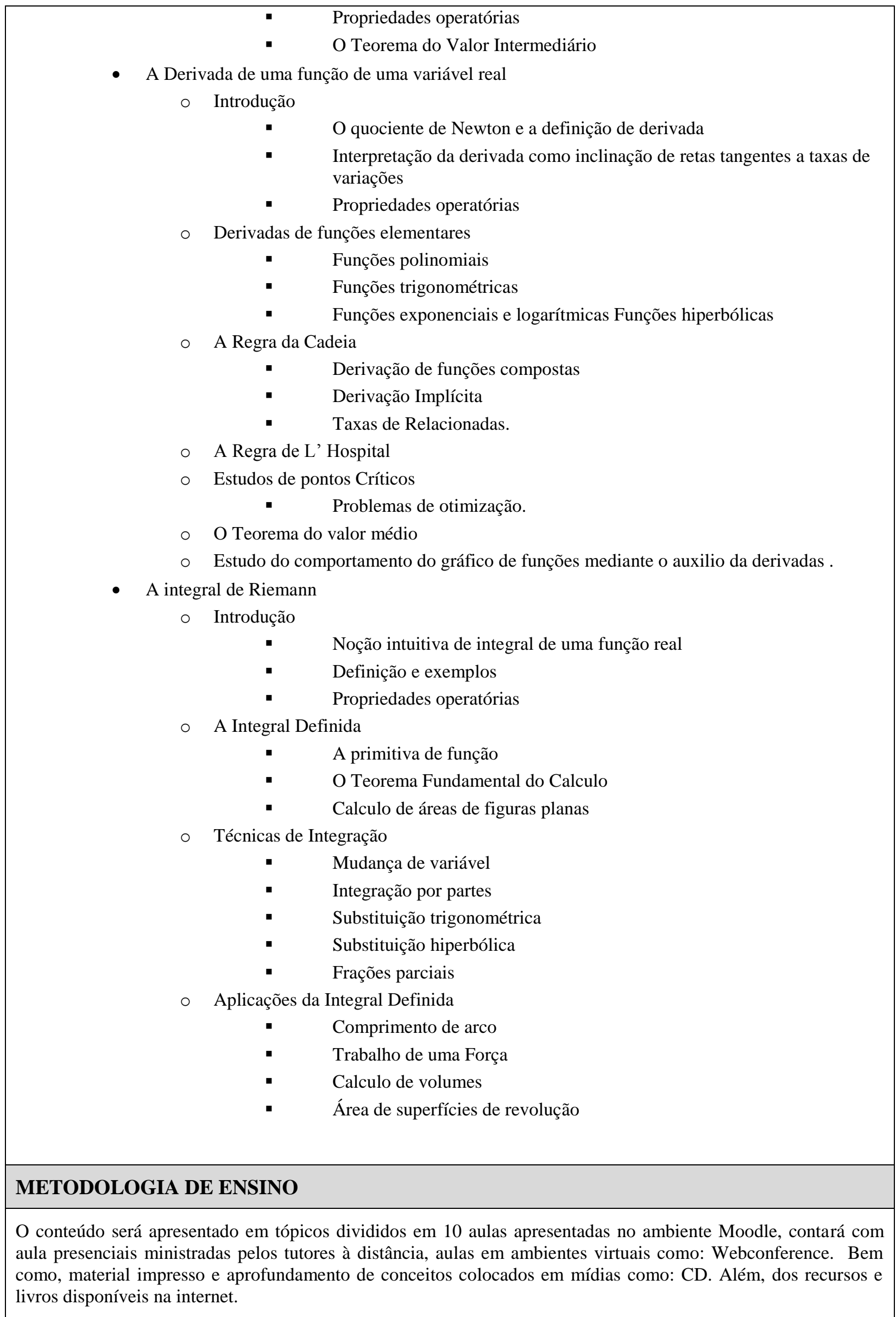




\section{AVALIAÇÃo}

A avaliação se dará através de fóruns, atividades postadas pelos alunos no ambiente e duas (02) avaliações presenciais realizadas nos polos.

BIBLIOGRAFIA BÁSICA

STEWART, J. Calculo, Volume I. 5ª Edição. São Paulo: Pioneira Thomson Learning, 2006.

LEITHOLD, L. O Cálculo com Geometria Analítica, vol. 1 - $3^{\text {a }}$ edição. São Paulo: HARBRA, 1994.

BIBLIOGRAFIA COMPLEMENTAR

GUIDORIZZI, H. Um Curso de calculo, Volume I. 5a Edição. Rio de Janeiro: LTC, 2002. 


\section{A NEXO I I - SUMÁRIO DO MA TERIAL DIDÁTICO DE C Á L C U L O I}

Apresentação 7

Referências 216

Currículo 217

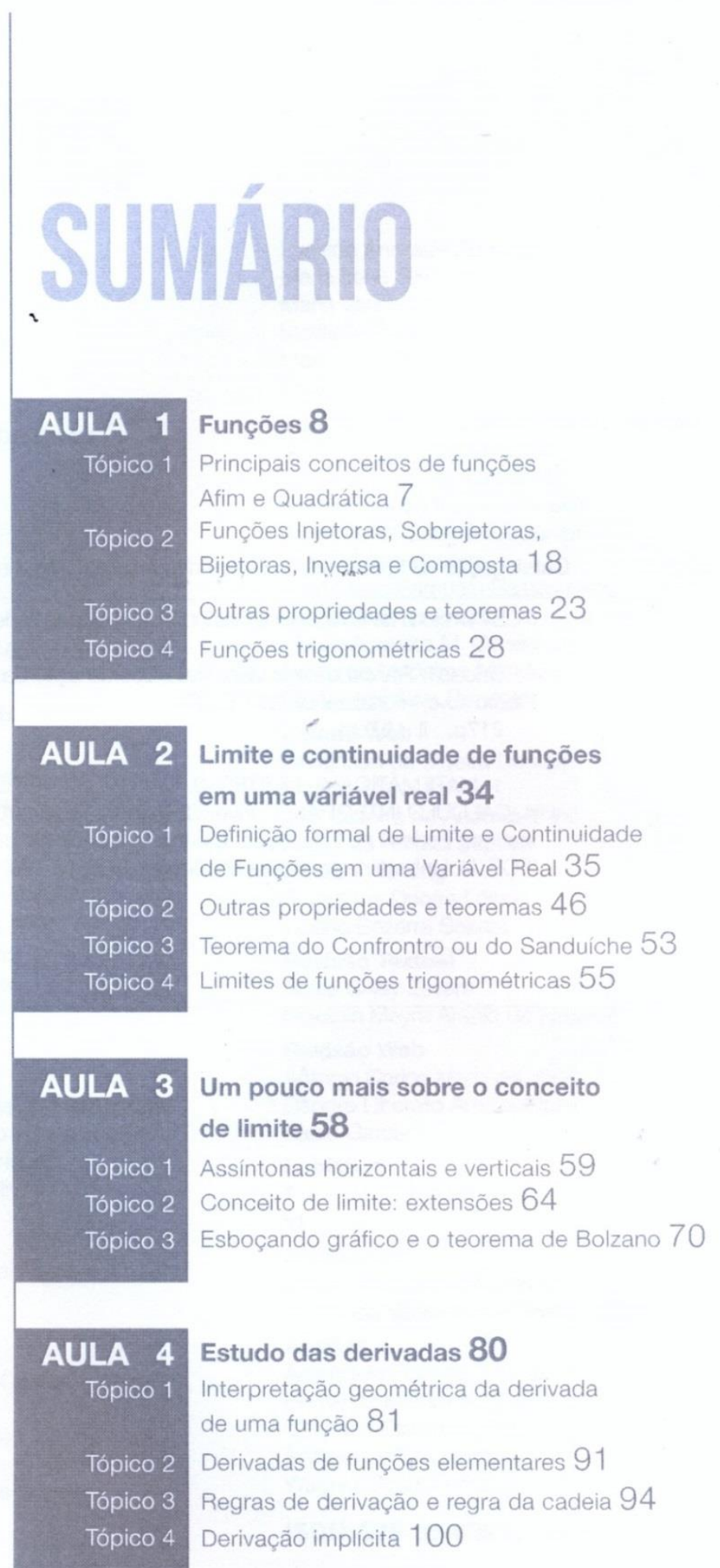




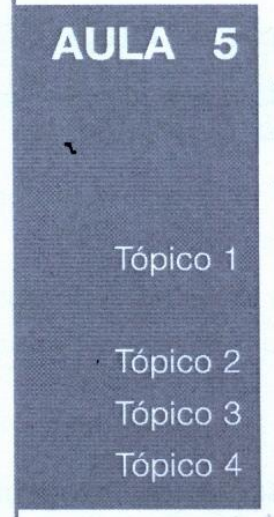

Derivadas de funções

trigonométricas inversas, derivada de ordem superior, taxas relacionadas e funções hiperbólicas 104

Derivadas de funções trigonométricas inversas 105

Derivada de ordem superior 108

Taxas relacionadas 111

Funções Hiperbólicas 115

AULA 6 Valores extremos de função, teorema do valor médio e a regra de L'Hospital 118

Tópico 1 Valores máxímos e mínimos 119

Tópico 2

O teorema do valor médio e a regra de L'hospital 128

\section{AULA 7 \\ Tópico 1 \\ Tópico 2

2

Estudo do comportamento do gráfico de funções mediante $o$ auxílio das derivadas 137

Informações obtidas a partir da primeira $e$ segunda derivadas de uma função 138

Miscelânea de exercícios resolvidos 146

\section{AULA 8 Integração 156}

Tópico 1

Tópico 2

Primitiva e Integral de uma função 157

A Integral de Riemann e o Teorema

Fundamental do Cálculo (TFC) 162

Tópico 3

Área de figura plana obtida entre curvas 170 


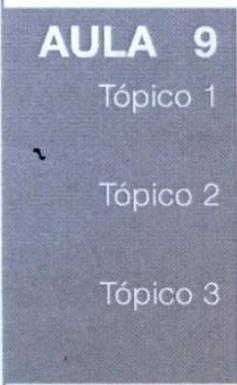

AULA 10 Tópico 1

Tópico 2

Tópico 3 Tópico 4

\section{Técnicas de integração 175}

Mudança de variável e integração por partes 176

Outras técnicas de integração: frações parciais 181

Outras técnicas de integração: Substituição Trigonométrica e Hiperbólica 186

Aplicações da integral definida 193

Comprimento de Arco 194

Área de superfície de revolução 199

Volumes de superfície de revolução 204

Trabalho de uma força 212 